Fall 1919

\title{
1919 Cedrus Yearbook
}

\section{Cedarville College}

Follow this and additional works at: https://digitalcommons.cedarville.edu/yearbooks

Part of the Higher Education Commons, Organizational Communication Commons, and the Public Relations and Advertising Commons

\section{Recommended Citation}

Cedarville College, "1919 Cedrus Yearbook" (1919). Yearbooks. 86.

https://digitalcommons.cedarville.edu/yearbooks/86

This Book is brought to you for free and open access by DigitalCommons@Cedarville, a service of the Centennial Library. It has been accepted for inclusion in Yearbooks by an authorized administrator of DigitalCommons@Cedarville. For more information, please contact digitalcommons@cedarville.edu. 


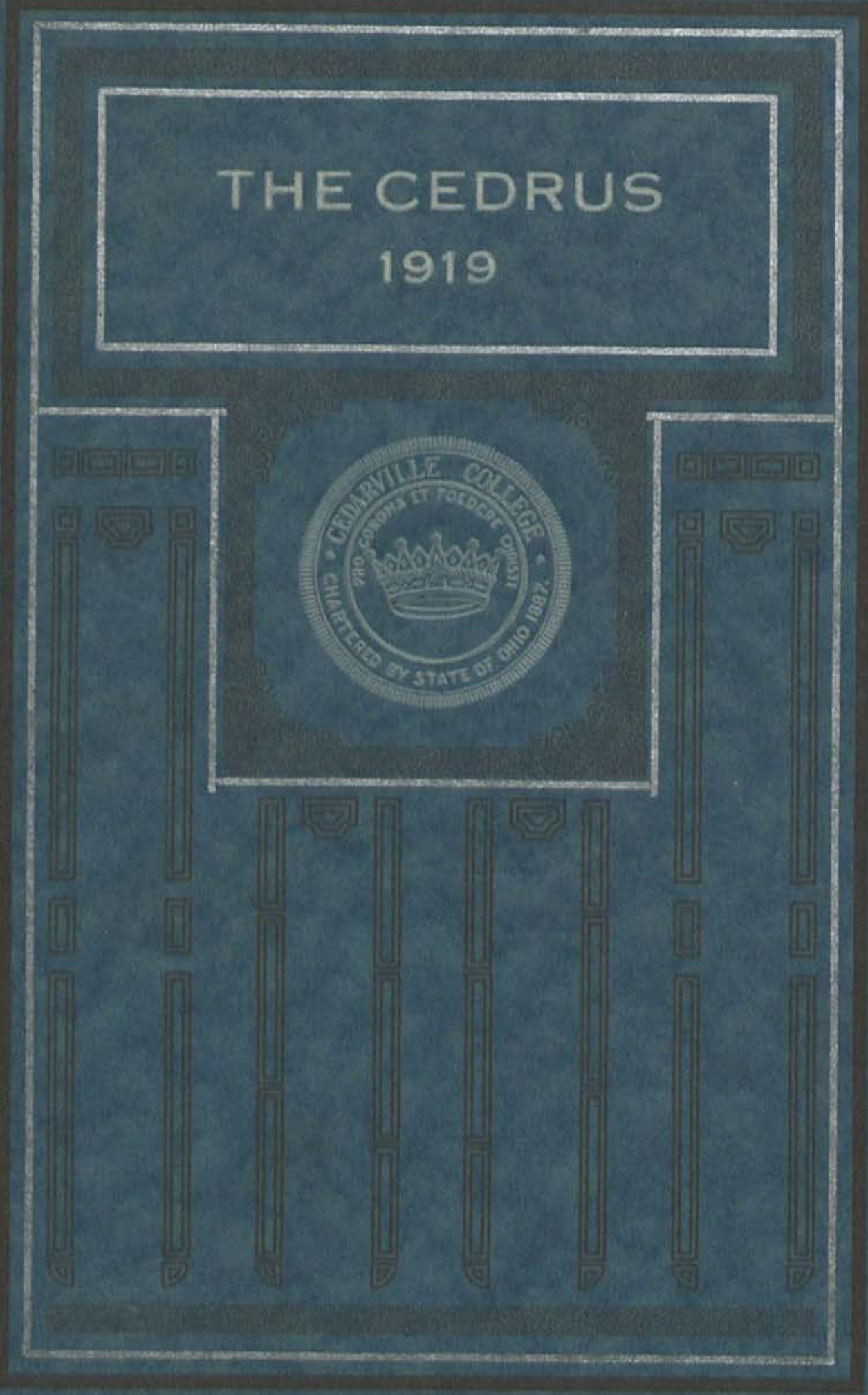




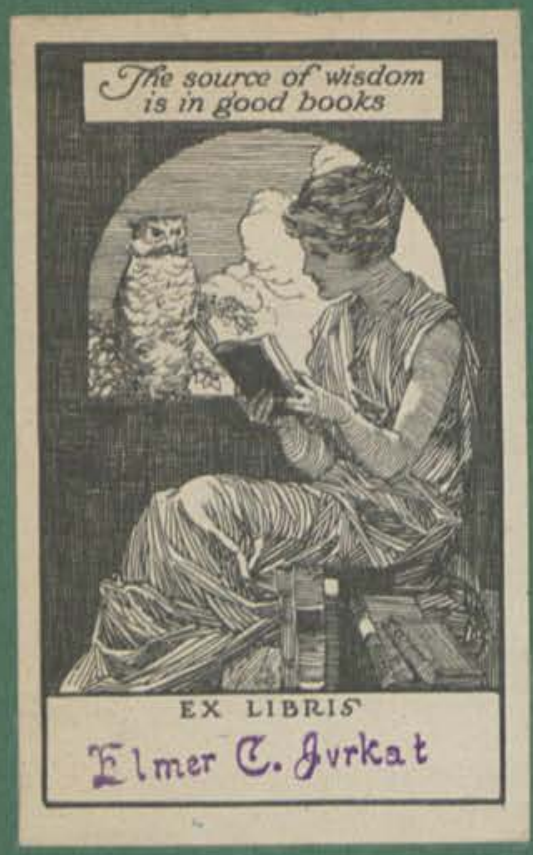




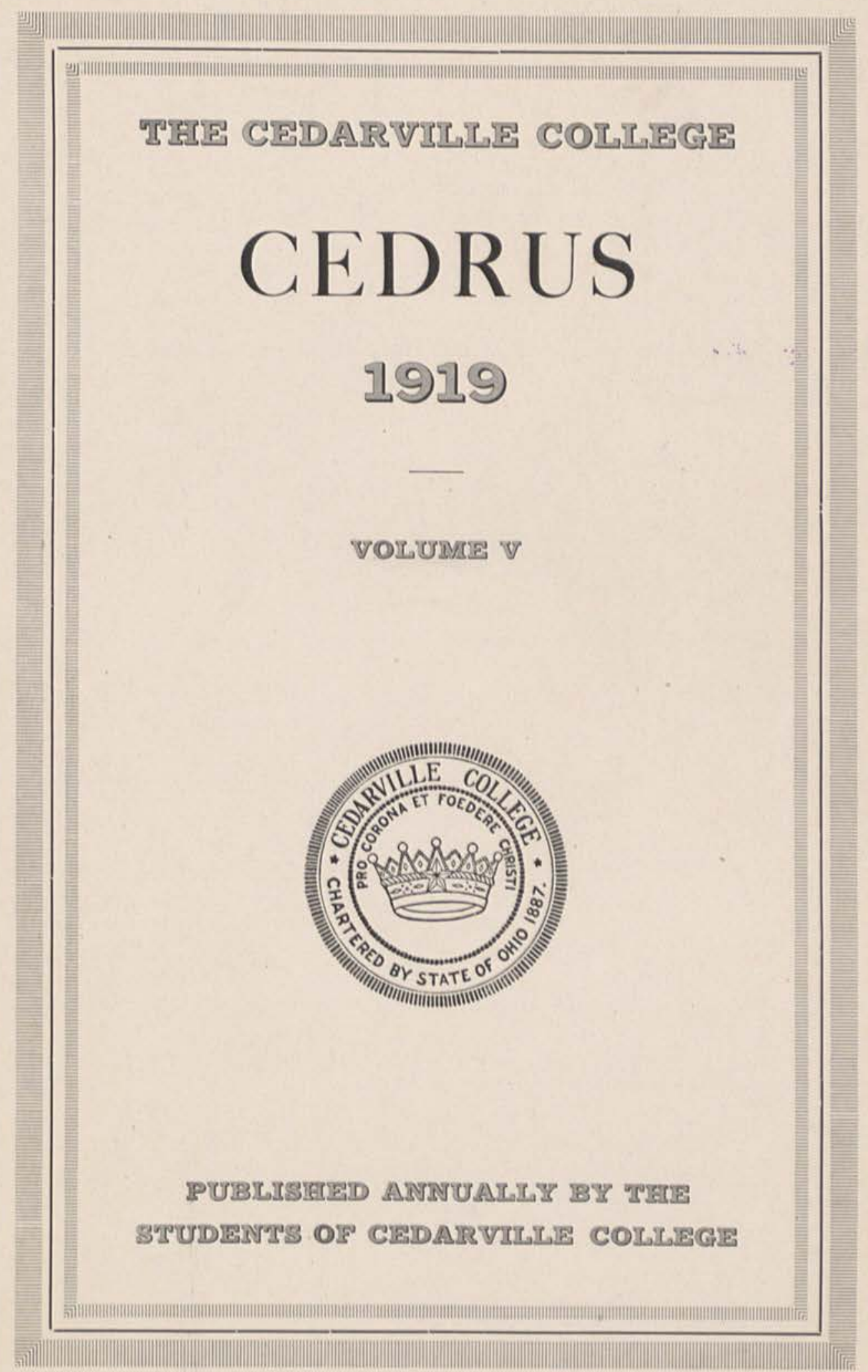



To

\section{JIrnfrisur Trenuy Allen}

WE HUMBLY DEDICATE

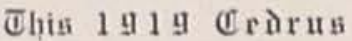

BECAUSE OF HS FRIENDLY AND HELPFUL.

INTEREST IN THE STUDENTS, AND HIS

FAITHFEL WORK TO THE COLLEGE 


\section{FOREWORD}

T IS true that a mirror does not reflect a correct copy of a letter held in front of it. It is only with difficulty that the image of the letter can be read. The letter may be a well-written one and no person would attempt to criticize it; yet the image would not be as easy to read as the letter itself. The Staff has tried to present the school year of nineteen hundred eighteen and nincteen in Cedarville College correctly in this 1919 CEDRUs. It may be that we have not succeeded and that this CEDRUs is only an incorrect image of the past school year. If you find this to be true, do not criticize the College, but if you must, criticize this Cedrus.

We have been able to present only in a small way the happenings of the critical year of our College, as well as the critical year in the history of the world. It was with some hesitation that school was opened in September, 1918. The World War caused conditions in the educational world to be uncertain. Although we entered the school year with the world at war, we have seen the end of the war, and we hope that the treaty of peace will soon be a reality.

We have no apology to offer for anything that you may find to criticize, for we have tried to do our best. We hope that no one will be offended and that this volume may be the predecessor of splendid annuals of a large and growing Christian institution of learning.

The Staff has eliminated all unessential reading material and has tried to make it a book for entertainment and not for study. We have tried to say, as did the men who were given a difficult task to perform, "We think we can do it," and we hope when you have this book we can say, as they did when they had completed the work, "We thought we could."

THE STAFF. 

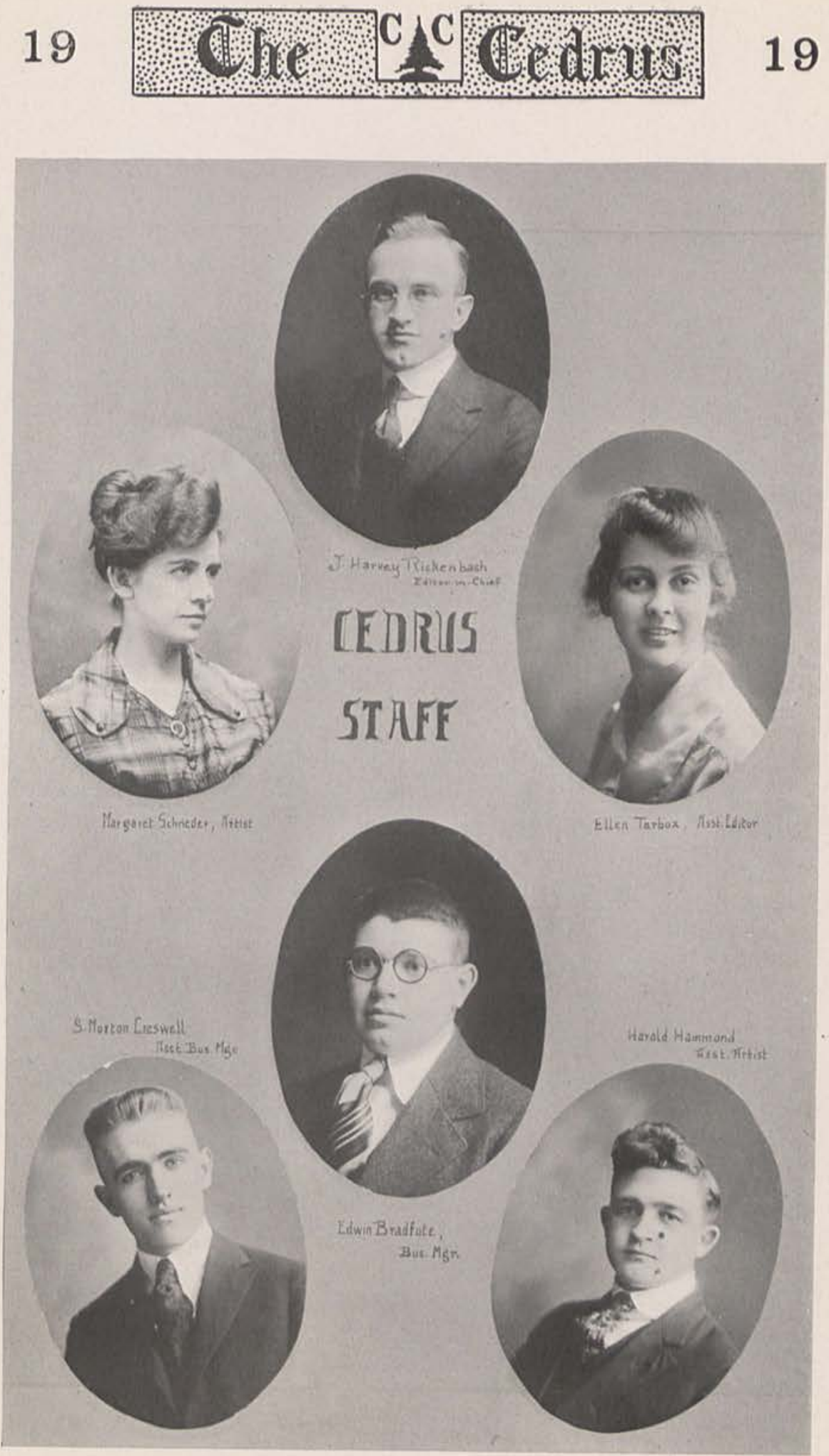

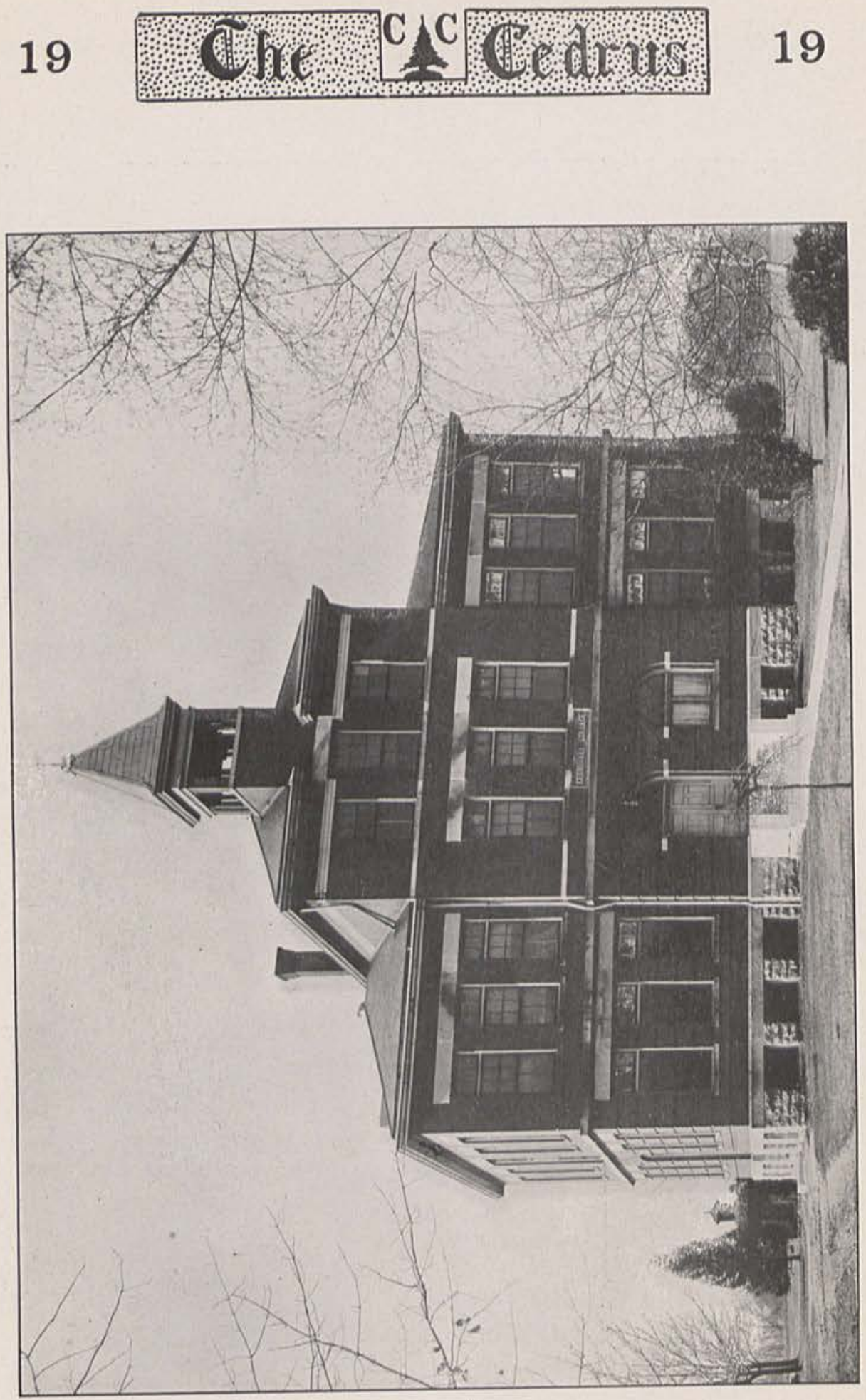

告 


\section{WHAT IS CEDARVILLE COLLEGE}

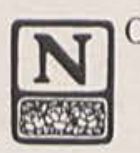

OT buildings, nor campus, nor books, nor equipment, nor even students nor professors make a college, but the spirit which permeates its life and dominates its activities. Ideas and ideals rule the world. Force and matter are but instruments. Even individuals, though for the time the source of idealistic elements, are in the larger sense subservient to them, for ideas are carried on through ages and by great groups, and cease not with the life of a man.

Cedarville College is the sum of the spiritual forces that by some process or series of processes have been brought to bear here, and now go on producing effects, for good or for ill, upon all brought within the radius of the institution's influence. The spirit of Cedarville College is difficult to analyze, but it may be characterized in three great words: as scientific, social, and religious.

It is scientific. Open-mindedness to new ideas is coupled with the critical attitude. "Prove all things; hold fast that which is good," is the motto. Truth, welcome or unwelcome, is the goal. It is reached by evidence and inference.

The spirit of Cedarville College is social. Sympathy for all things human is cultivated. The desire for mutual helpfulness is developed. The missionary incentive to carry the gospel of love to those most in need of it, counterbalances the natural tendency toward too much egoism.

This spirit is also religious. There is the firm belief in high ideals, heaven-inspired; in a kingdom of heaven to be established on earth; in divine help in the attainment of all lofty purposes; and in man's responsibility for the manner in which he uses the good gifts of his Creator.

Is the spirit of Cedarville Christian? In the highest sense of the word, it is, because the Christian spirit is made up of these same elements. The Berean attitude of inquiry and proof, the social interest of Jesus, and the Biblical doctrine of a Universal Father, are the accepted bases of our college spirit. In the modern world there is coming to be more and more recognition of these as the highest ideals of the race. Let us hold them ever before us. 


\section{BOARD OF TRUSTEES}

\section{CLASS OF 1919}

James H. Creswell

Cedarville, Ohio

Rev. Homer McMillan, A. B., D. D., '97 Atlanta, Ga.

Rev. David McKinney, D. D., LL. D. Cincinnati, Ohio

Rev. Robert Bigham Wilson," A. B., D. D., '01 Jacksonville, Ill.

\section{CLASS OF 1920}

W. C. Iliffe Cedarville, Ohio

Oscar E. Bradfute, First Vice-President Xenia, Ohio

Rev. W. R. McChesney, Ph. D., D. D. Cedarville, Ohio

S. C. Wright, A. B., '03, Secretary Cedarville, Ohio

\section{CLASS OF 1921}

Prof. F. A. Jurkat, A. M., LL. D., Treasurer. Cedarville, Ohio Nathan L. Ramsey, Second Vice-President_ William Conley, President Cedarville, Ohio Judge J. C. Marshall, A. B., ’07 Cedarville, Ohio Xenia, Ohio

\section{STANDING COMMITTEES OF THE BOARD}

Executive-McChesney, Bradfute, Marshall, Conley.

Finance-Creswell, Wilson, Ramsey, Iliffe.

Instruction-McMillan, McChesney, Wilson, Marshall.

Property_Bradfute, Jurkat, Ramsey, Wright.

Auditing-Wright, Iliffe, Conley.

Investment-Jurkat, McKinney, Bradfute, McChesney.

\section{LOCAL ADVISORY BOARD}

D. S. Ervin, J. C. Stormont, Thompson Crawford, G. E. Jobe, Oscar Smith, Dr. Miron I. Marsh.

\section{WOMEN'S ADVISORY BOARD}

Miss Mary B. Ervin, A. B., ’02; Mrs. John W. Johnson; Mrs. W. H. Barber; Mrs. W. R. McChesney, President; Mrs. Anderson Collins; Mrs. E. C. Oglesbee; Mrs. G. H. Creswell; Mrs. Leroy Allen, '18, SecretaryTreasurer; Mrs. L. A. Parker, Mrs. S. C. Wright.

*Died June 26, 1918. 


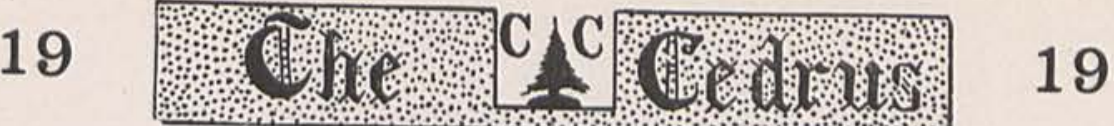

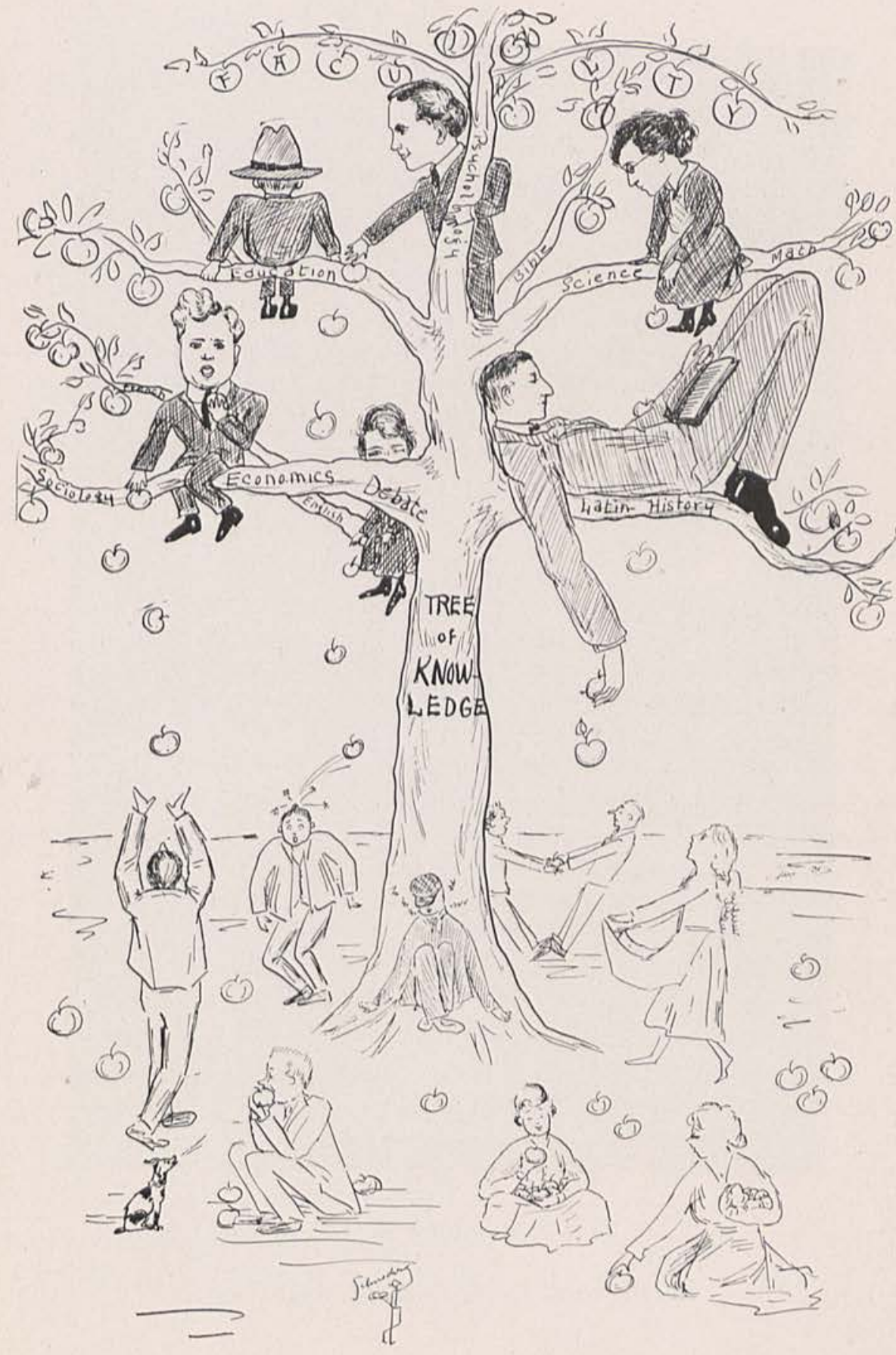



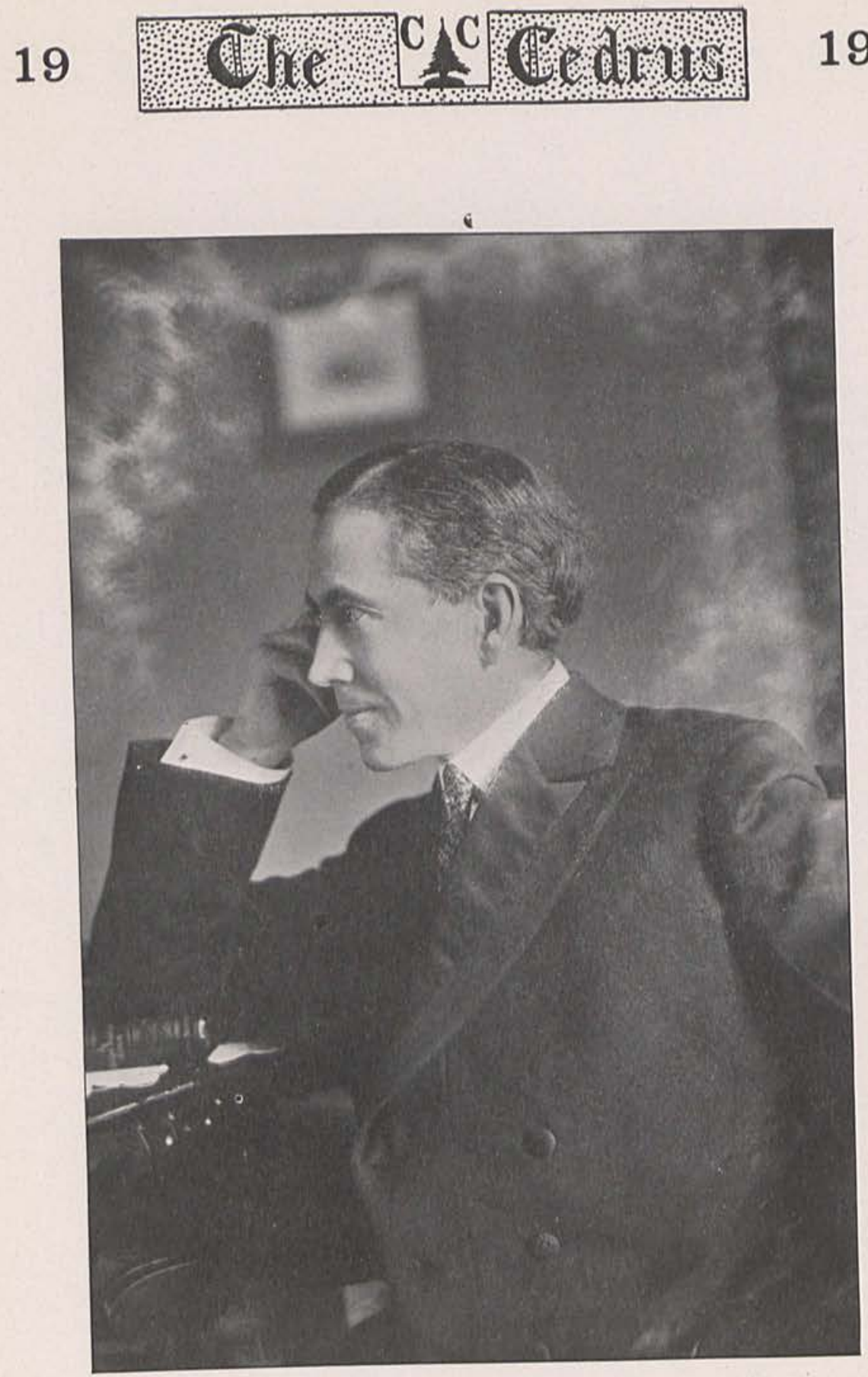

W. Renwick McChesney, PH. D., D. D. President

Professor of Psychology, Oratory, Greek 

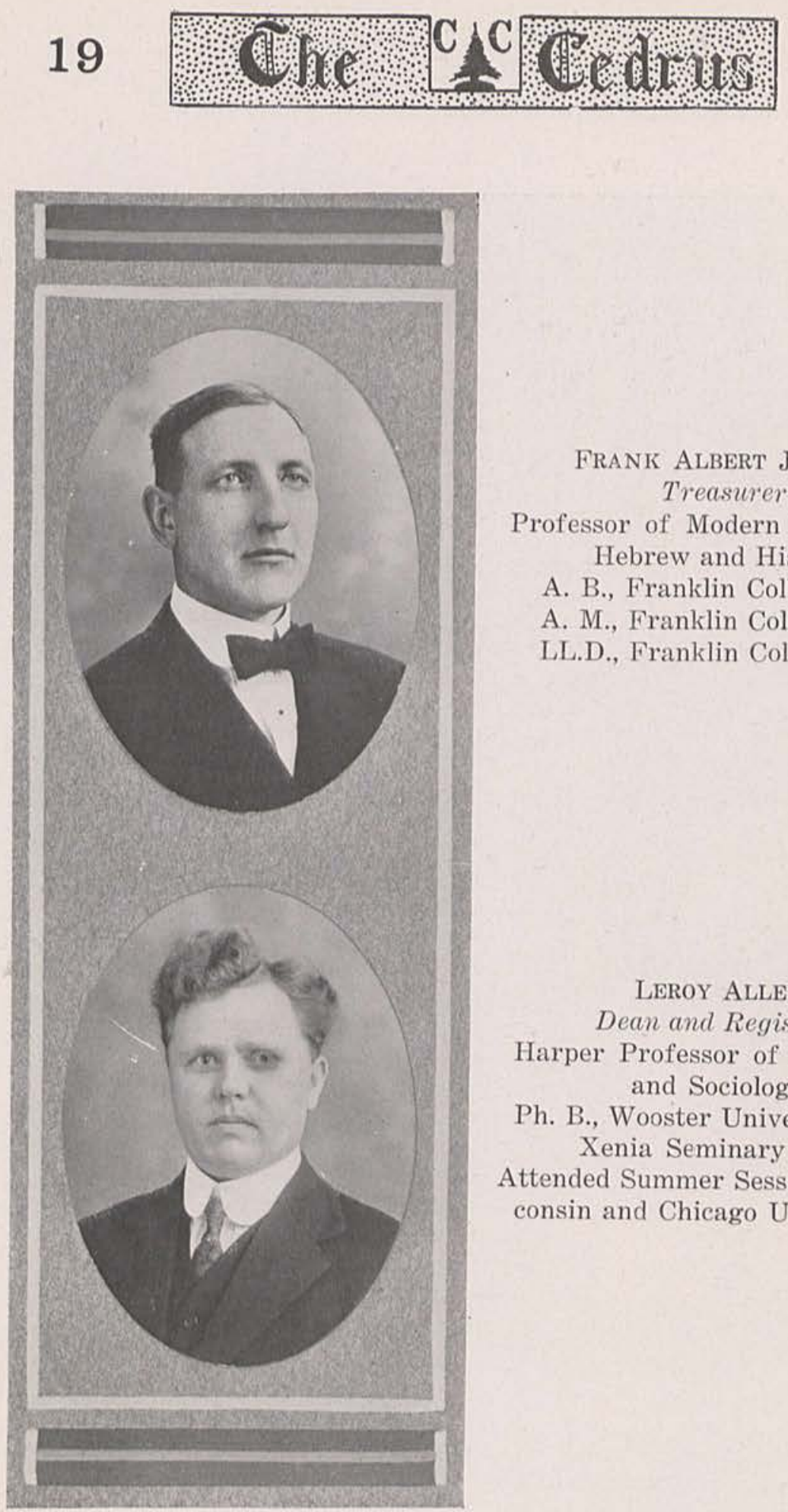

Frank AlbERT JURKAT Treasurer

Professor of Modern Languages, Hebrew and History

A. B., Franklin College 1895

A. M., Franklin College 1898

LL.D., Franklin College 1917

\section{LEROY ALLEN \\ Dean and Registrar.}

Harper Professor of Economics and Sociology

Ph. B., Wooster University 1906

Xenia Seminary 1914

Attended Summer Sessions at Wisconsin and Chicago Universities 


\title{
19
}
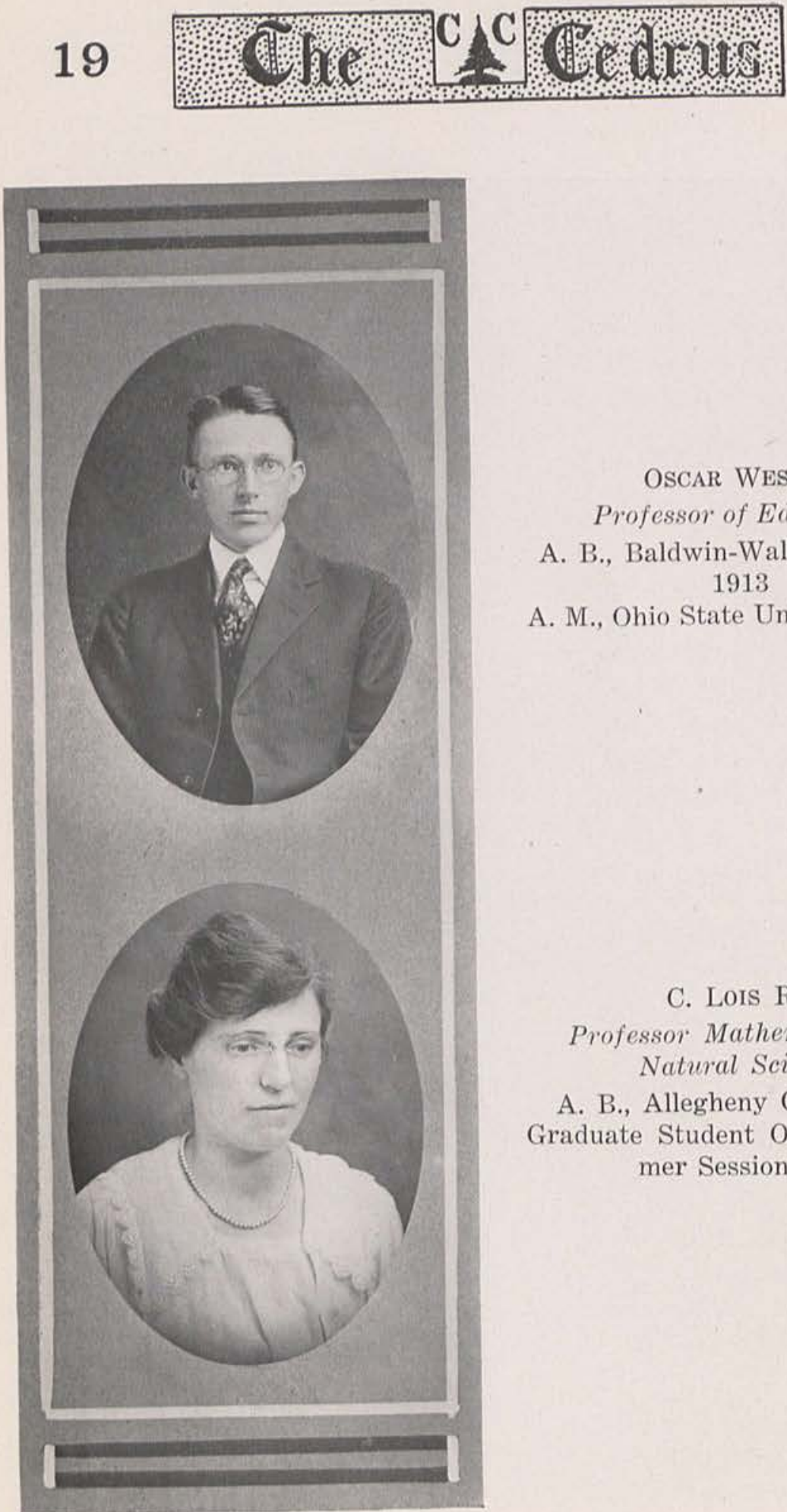

\author{
OSCAR WESLEY \\ Professor of Education
}

A. B., Baldwin-Wallace College 1913

A. M., Ohio State University 1918

\section{LOIS REA}

Professor Mathematics and

Natural Sciences

A. B., Allegheny College 1914

Graduate Student O. S. U., Summer Session 1918 


\section{9 -6) 19}
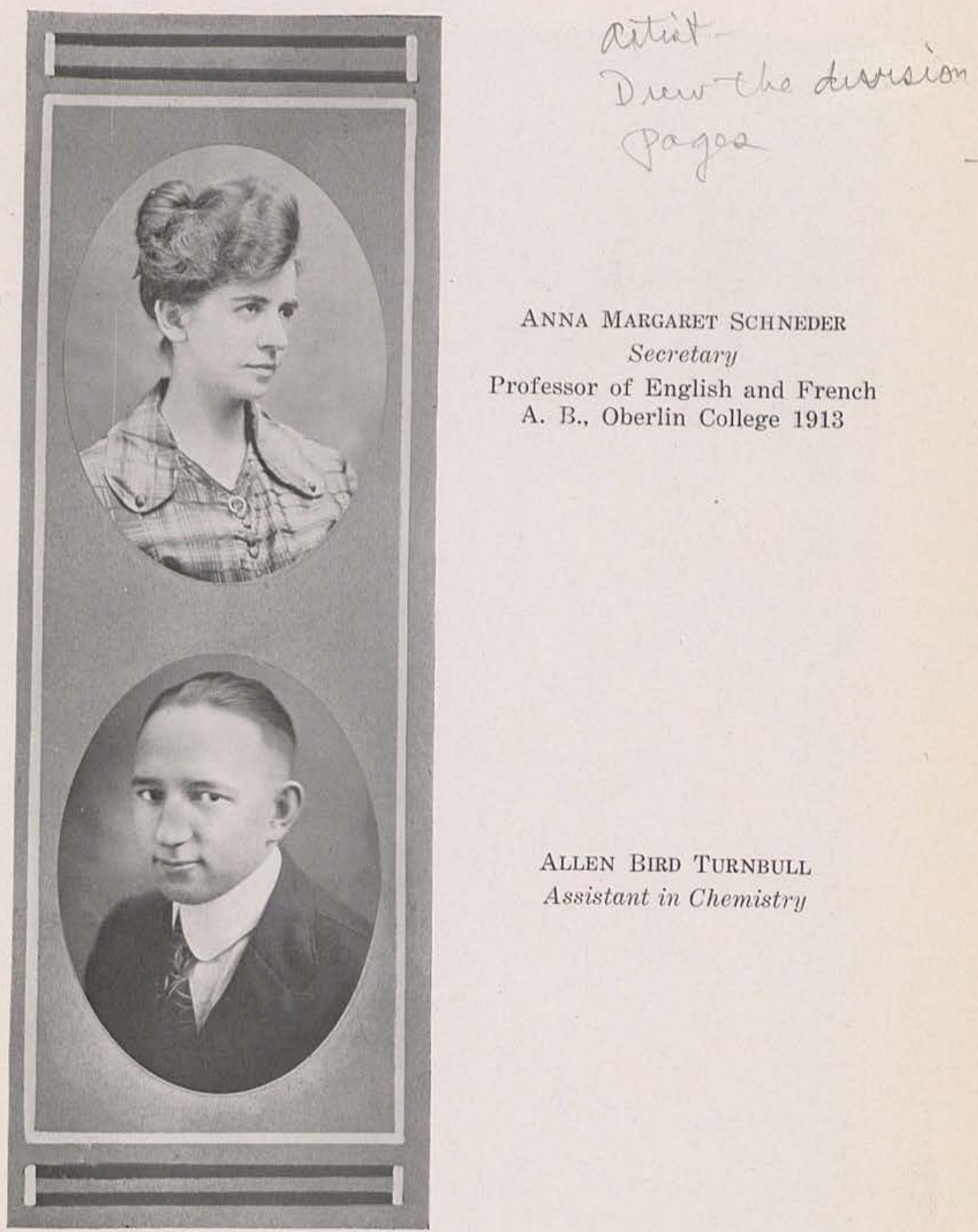

\section{ANNa Margaret SCHNEder \\ Secretary}

Professor of English and French

A. B., Oberlin College 1913

Allen Bird Turnbull Assistant in Chemistry 

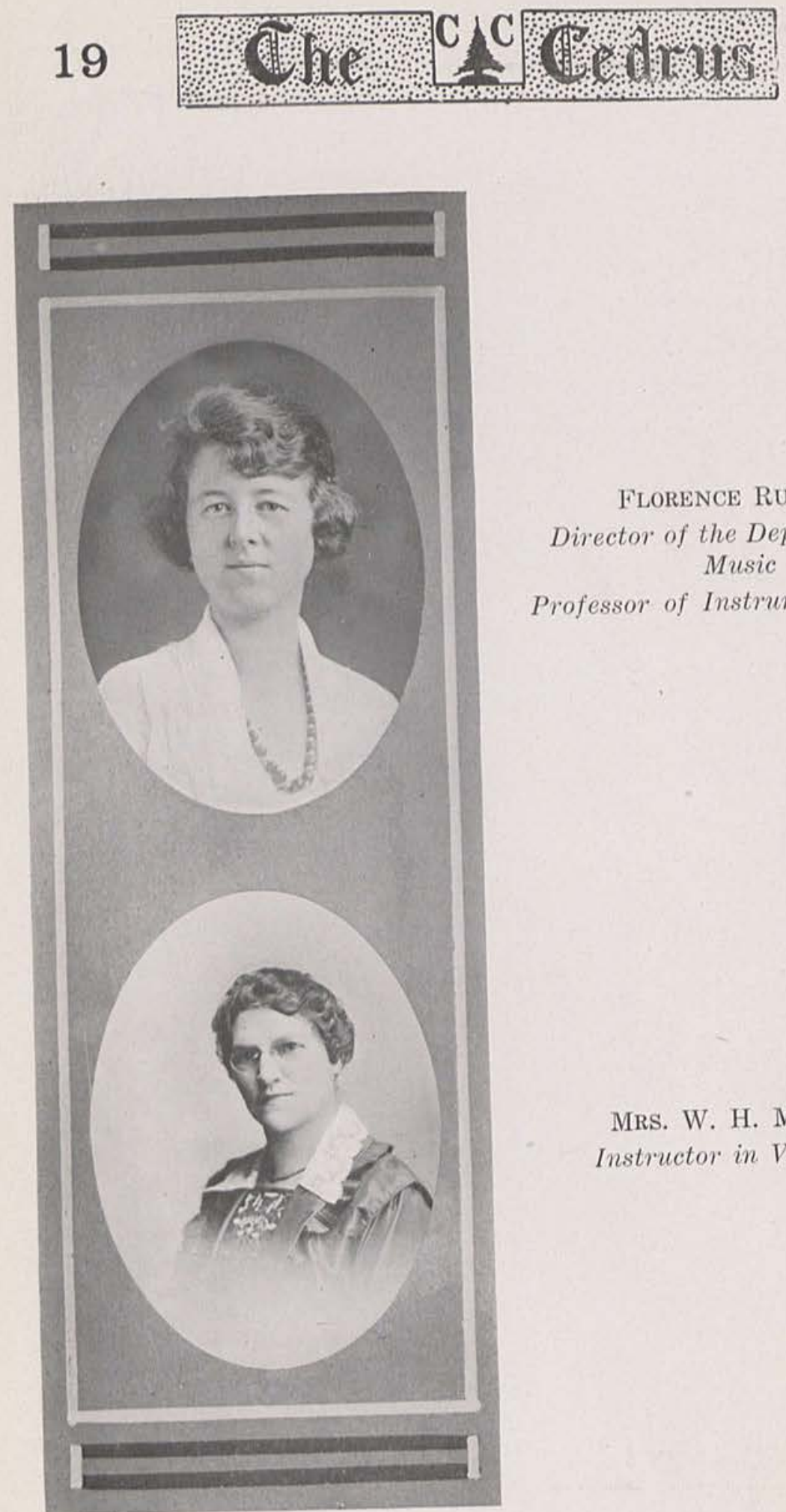

Florence Russell

Director of the Department of Music

Professor of Instrumental Music 

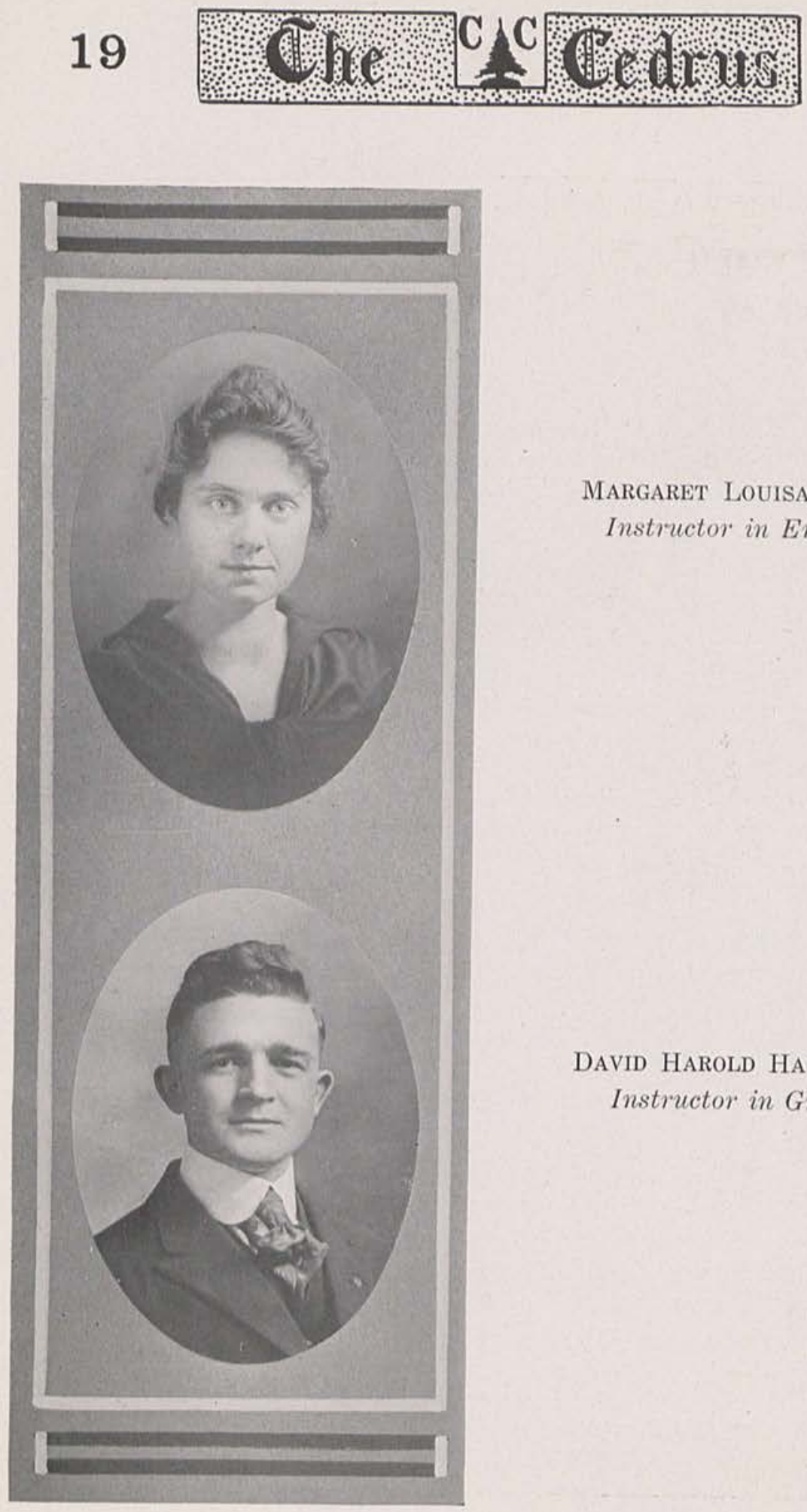

MARgaret Louisa Greir

Instructor in English

DAVID HAROLD HAMMOND

Instructor in Greek 


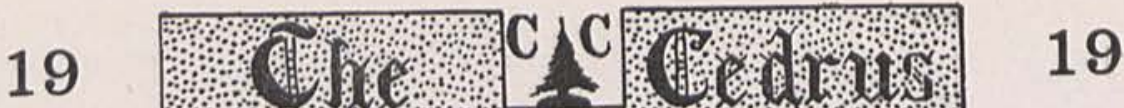

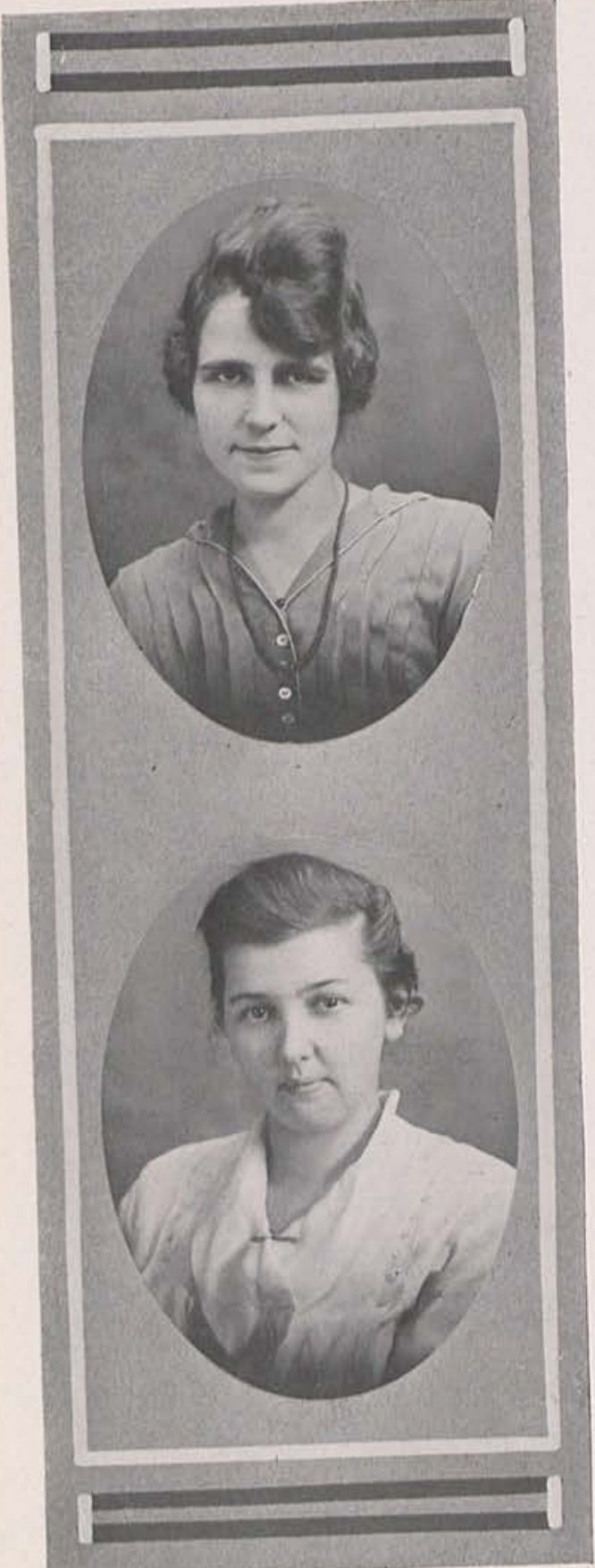

Marguerite Marie Gilkey Instructor in English

MARgaret ELLEN ELDER Instructor in Latin 


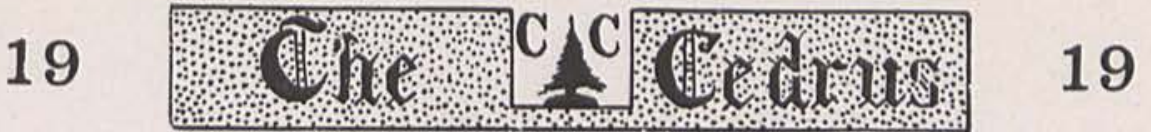

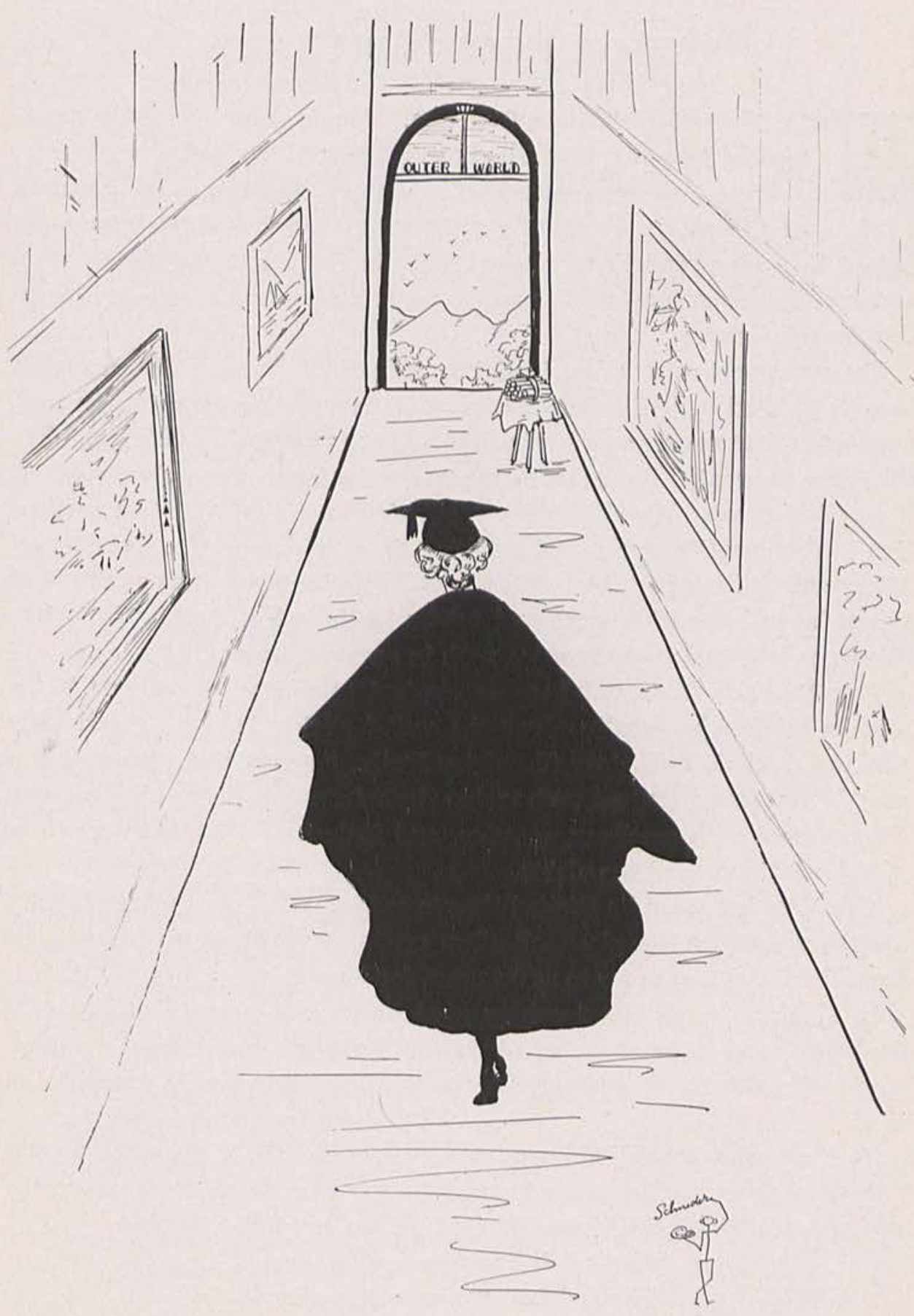




\section{9}

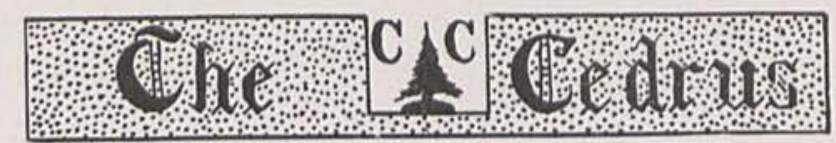

\section{SENIOR CLASS OBITUARY}

ORN September 15, 1915, $9: 30$ A.M. Passed from the weary struggle and joys of college life, June 6, 1919, 11 :30 A.M.

Though we are opposed to the custom and habit of the majority of the people in waiting until their friends and foes have departed to place a wreath of remembrance in the place that knows them no more, we are constrained to pause for a few moments in reflection upon this departed class.

The average person, unless biased or prejudiced, forms a like or dislike to an individual at the first meeting; and now the writer, living in the past, recalls his first meeting with this class and the impressions received. Enthusiasm permeated its entire being, or, in the language of the "vulgar," it was full of pep. How like a youth entering upon life, full of determination to conquer the world, and thinking there is no one like himself, yet after being initiated in the conflict and facing the actualities of life soon succumbs to his environment and settles in the mire of self-satisfaction like those who had trod the same path in previous years.

Thus the class, filled with hope, succumbed, after a bitter struggle, to the attacks led by the faculty along the well-fortified lines of PsychologyEconomics-Rhetoric-History-Chemistry-Math., "a load that would sink a navy." Not being content with trying the spiritual man, the physical man was plagued with smallpox, measles, and influenza. Yet from all these afflictions it emerged the victor.

This class has spent its allotted time in college. Had one time to enumerate the virtues of this class, all other matter would have to be excluded from the CEDRUs in order to make room for its history.

In all sincerity, it has fought a good fight; and when the time of its departure came, it entered confidently and joyfully into the great unknown world of reality, truly grateful for the privileges and benefits received at C. C.

To those who are still enjoying college life, the Senior Class leaves this message: "May you endeavor to emulate this class in all its most worthy traits and lift high the banner of dear old Cedarville."

"Men's evil manners live in brass;

Their virtues we write in water."-Ibid.

-R. N. C. 


\section{A SENIOR'S REVERIE}

Yes, we're grave and reverend Seniors, now. Our school days are nearly o'er;

And as the end of the year draws nigh, Feelings never known before

Come surging over us. Are we sorry or glad? And what will the future reveal?

Are we fitted to fill the place in life We've prepared for, with hope and zeal?

Then we think back over the years past and gone, And review them one by one.

The Freshman-Sophomore-Junior years, Filled with study, work, and fun.

This year has been one of sadness and joy; Some prospered, some illy have fared.

As a college, we've lost some endeared to us here As a class, we have all been spared.

Many fond memories come before us now As we live through the past anew;

And we're filled with hope that we'll ever be To our college loyal and true.

We have had our good times-yes, and lots of them, too; Some I'm sure we shall often recall.

We're "exclusive." When we have class spreads, you know, Others never get in at all!

Our evening spent out at the Collins home We'll remember, without a doubt,

Both those who, without, gazed longingly in, And those within who gazed out.

How vividly the scene comes before us now!

We again taste those "bricks" so rare,

And what is that noise creeping into our ears?

$\mathrm{Ah}$ ! It sounds like the clipping of hair!

Yes, we've had our good times together here, Loyal friendships have been made;

And as we enter upon our life tasks,

These mem'ries shall never fade.

We'll often think of the days spent together, And our hearts will quicken, I ween,

When we think over our college days And the dear old class of ' 19 . 


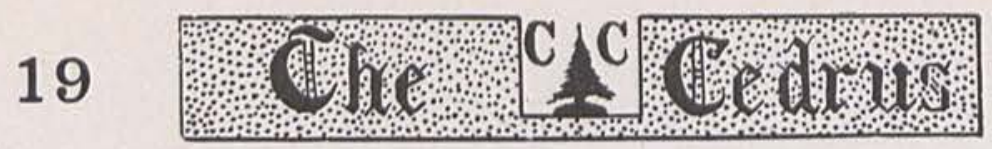

19

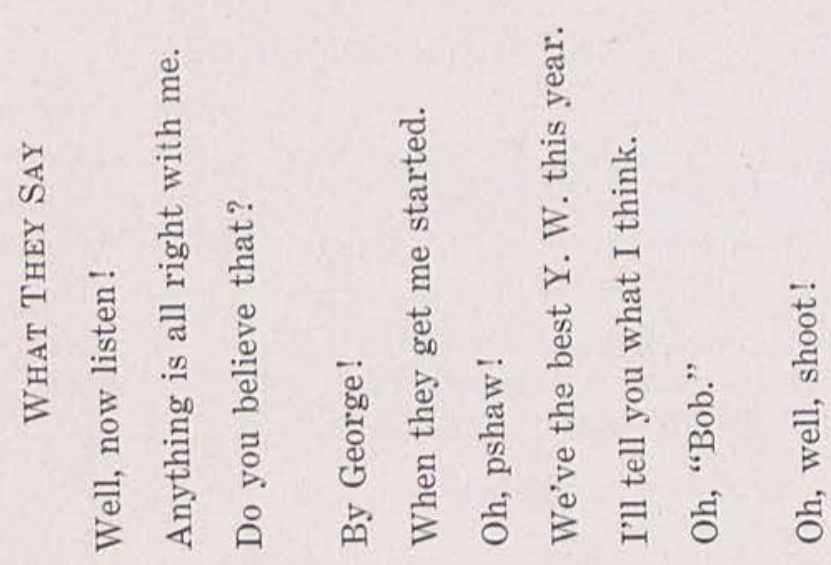

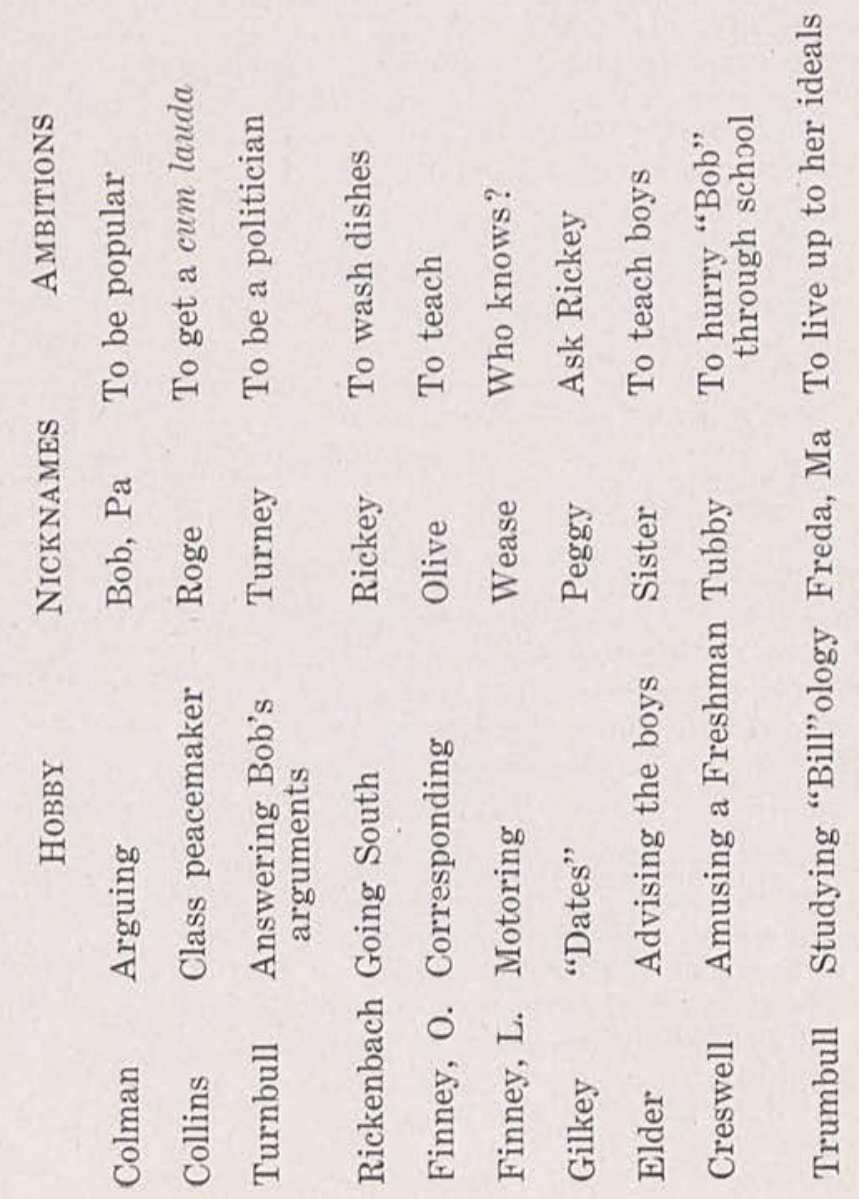




\section{9}
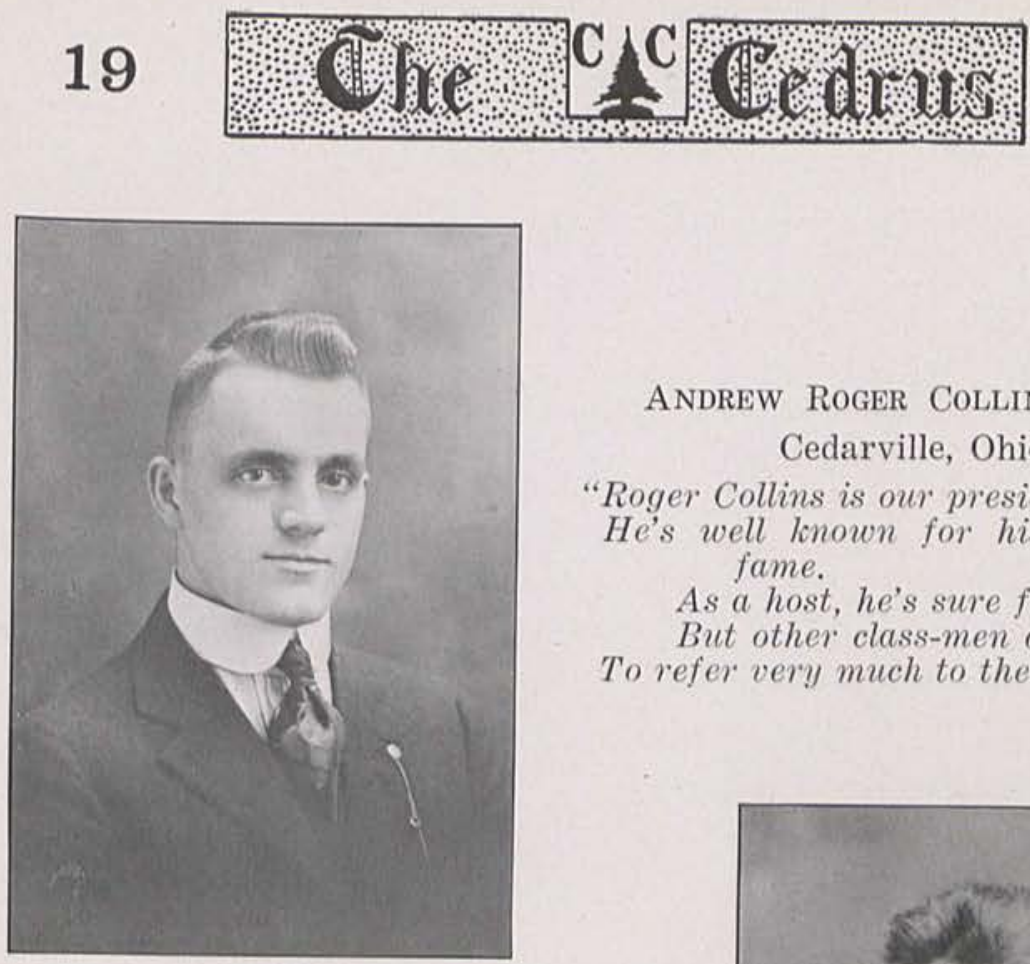

ANDRew Roger Collins, A. B.

Cedarville, Ohio

"Roger Collins is our president's name. He's well known for his basket-ball fame.

As a host, he's sure fine,

But other class-men decline

To refer very much to the same."

Freda Frances trumbull, A. B. Belle Center, Ohio

"Our Freda's a sweet, gentle maid,

Whose glory, we know, shall not fade.

Oh, a teacher she'll be,

But I think we'll all see

Housekeeping will soon be her trade."
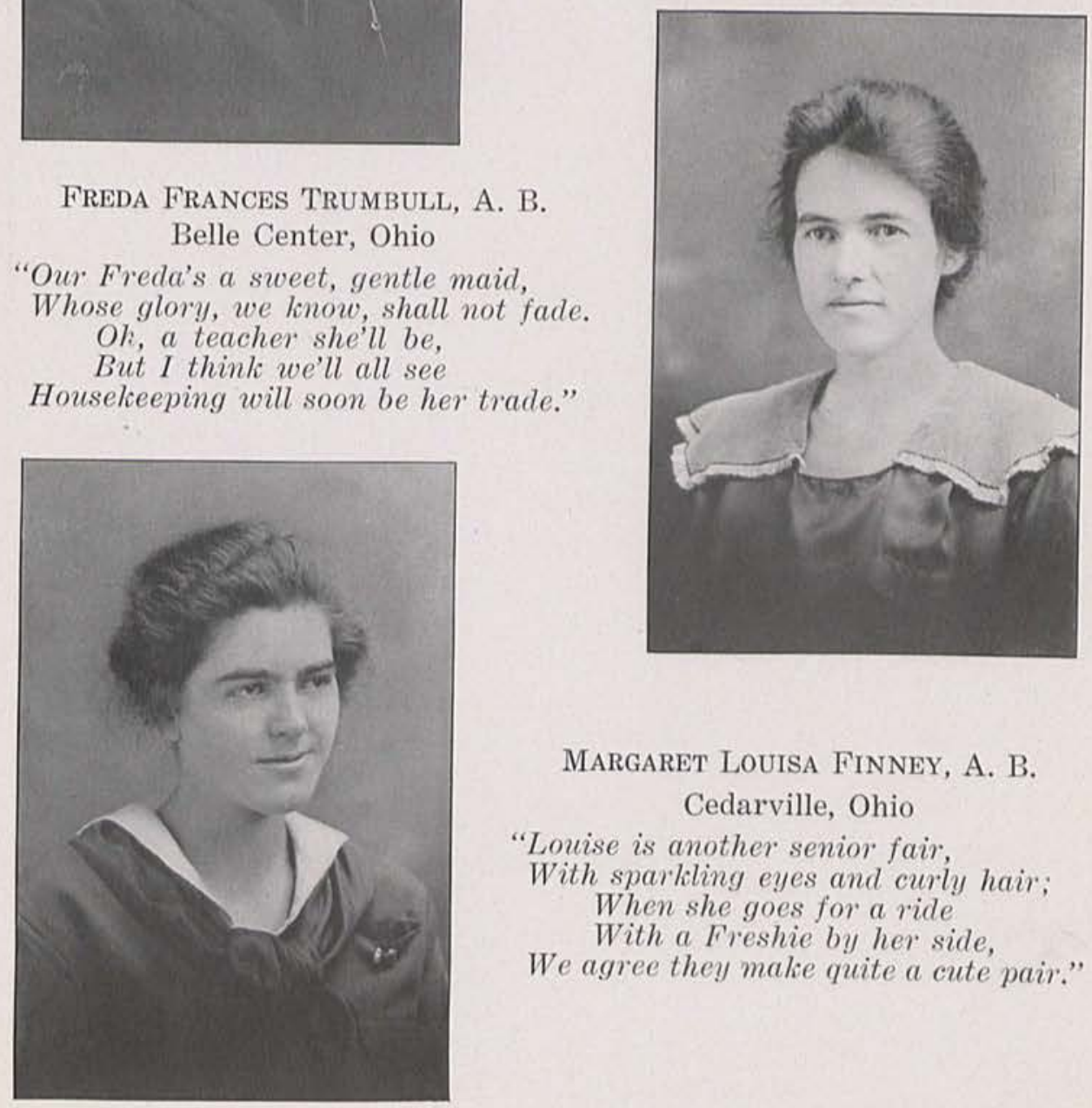

Margaret Louisa Finney, A. B.

Cedarville, Ohio

"Louise is another senior fair,

With sparliling eyes and curly hair;

When she goes for a ride

With a Freshie by her side,

We agree they make quite a cute pair." 


\section{9}
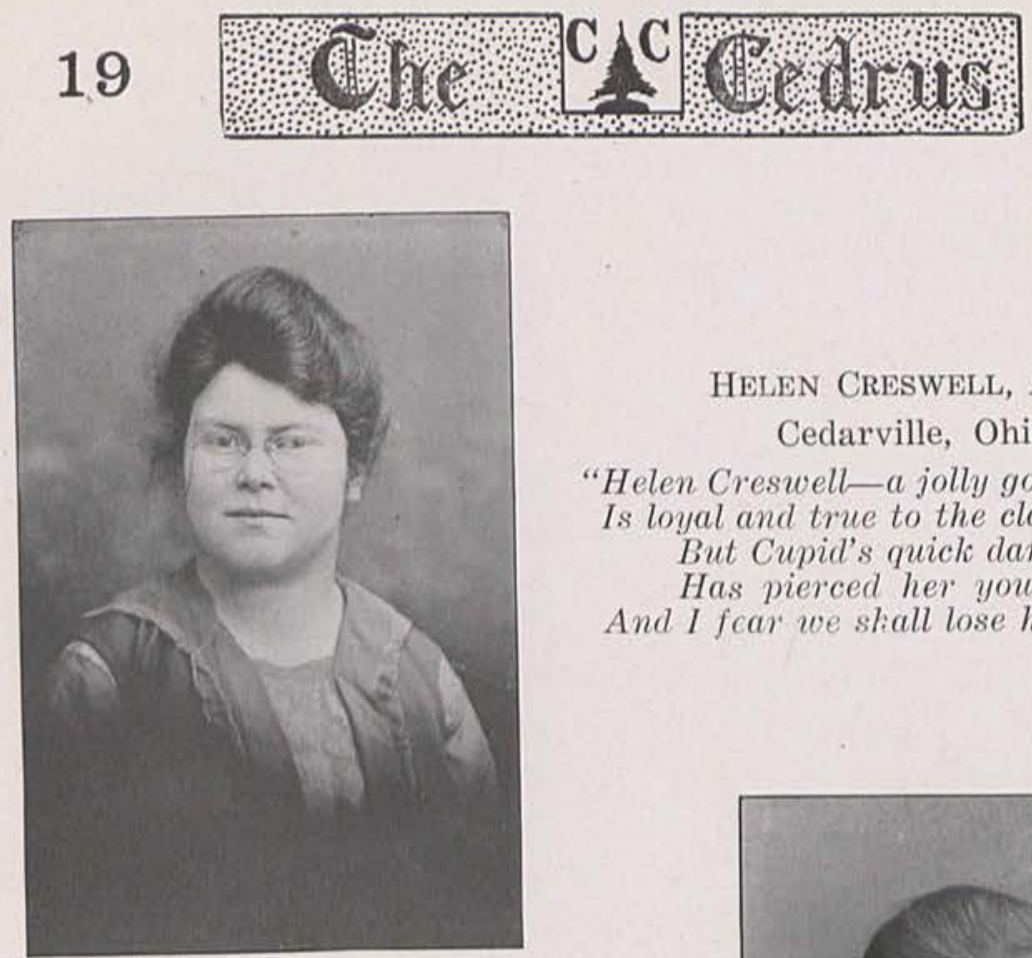

Helen Creswell, A. B.

Cedarville, Ohio

"Helen Creswell—a jolly good lass, Is loyal and true to the class;

But Cupid's quick dart

Has pierced her young heart, And I fcar we shall lose her, alas!"

Margaret Elien Elder, A. B.

Darlington, $\mathrm{Pa}$.

"Our Margaret is a friend to each one, Ever ready for work or for fun; She cut lab, one fine day-

Took in a movie, they say-

Has the second age of miracles begun?"
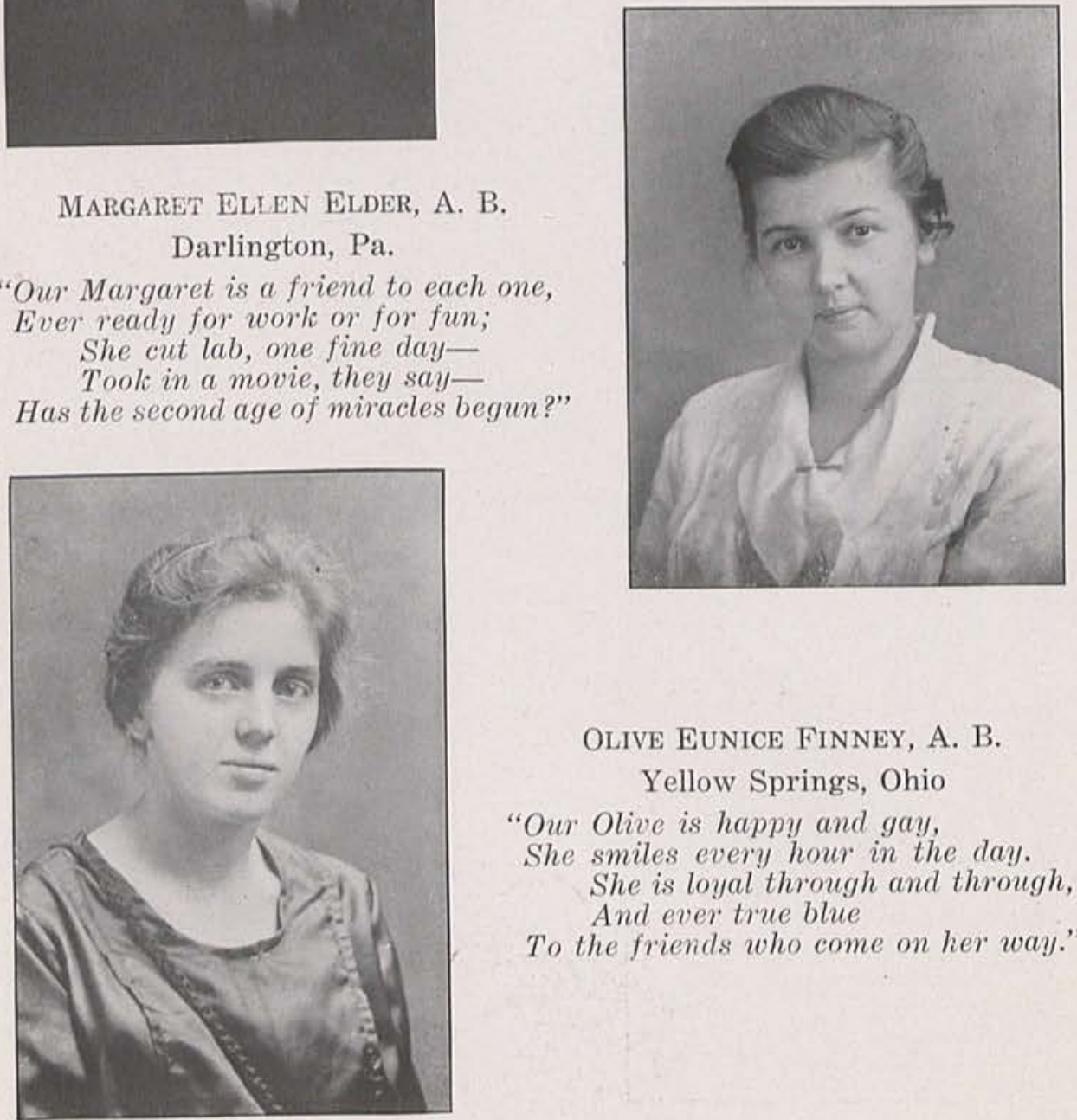

Olive Eunice Finney, A. B.

Yellow Springs, Ohio

"Our Olive is happy and gay,

She smiles every hour in the day.

She is loyal through and through, And ever true blue

To the friends who come on her way." 


\section{9}
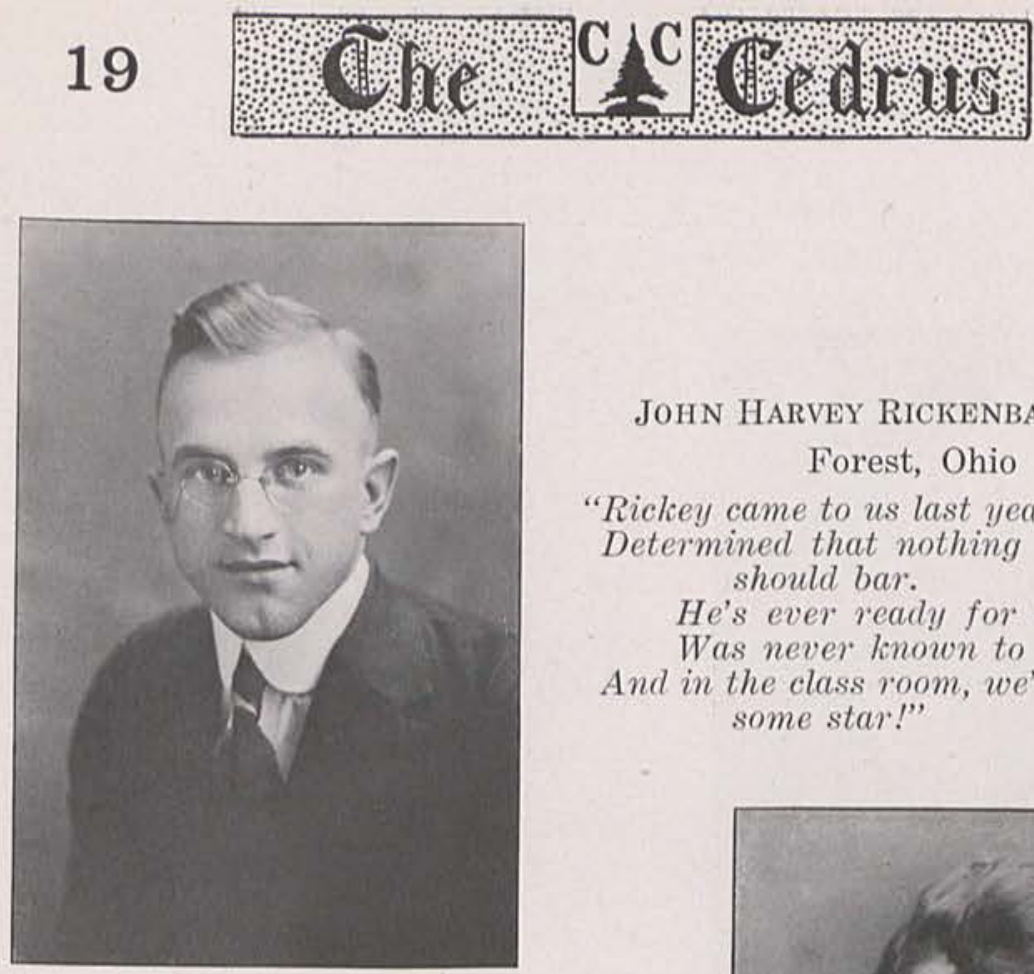

JOHN HARVEY RICKENBACH, A. B.

Forest, Ohio

"Rickey came to us last year from afar, Determined that nothing his learning should bar.

He's ever ready for work,

Was never known to shirk,

And in the class room, we'll admit he's some star!"

Marguerite Marie Gilkey, A. B. Cedarville, Ohio

"This charming young girl, Marguerite, Has chanced her intended to meet. I am sure that all

Of our band, great and small,

Will agree with him that she's quite sweet."
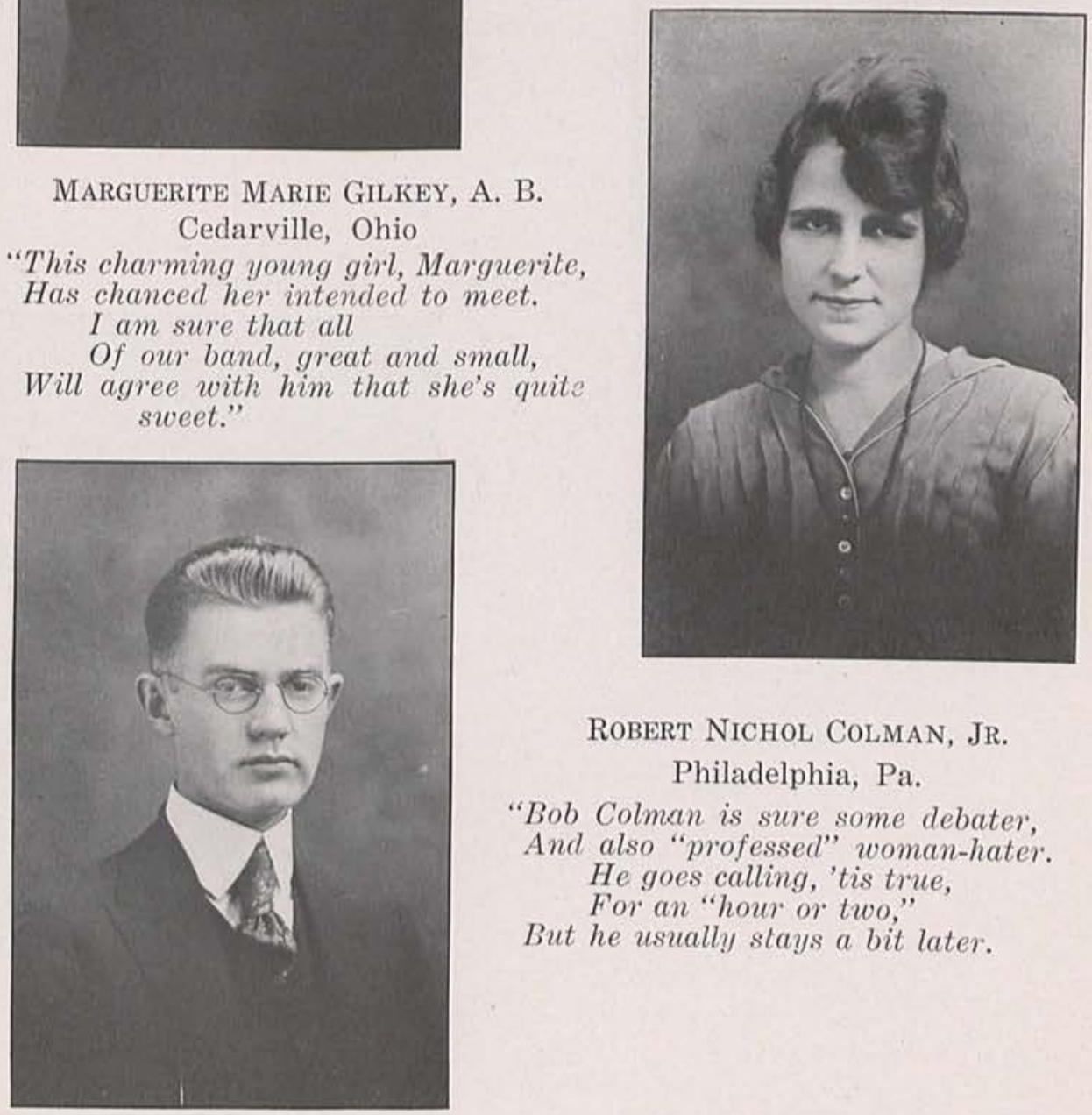

ROBERT Nichol COLMan, JR.

Philadelphia, Pa.

"Bob Colman is sure some debater,

And also "professed" woman-hater.

He goes calling, 'tis true,

For an "hour or two,"

But he usually stays a bit later. 


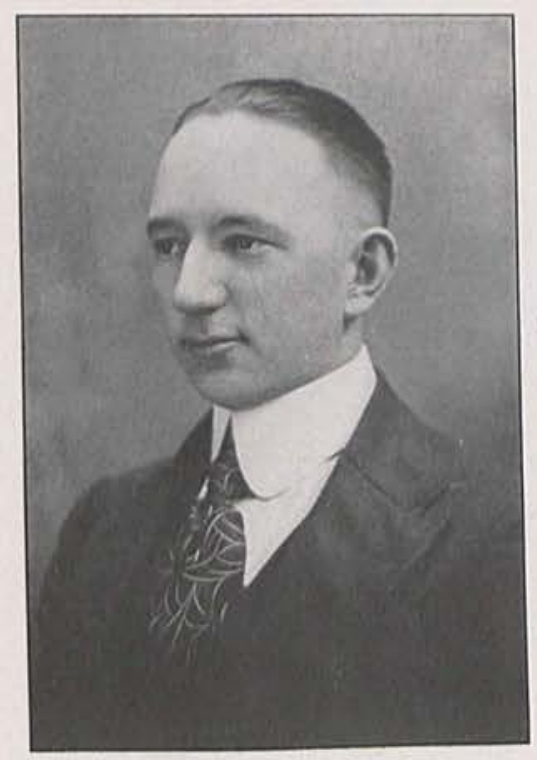

Allen Bird Turnbull, A. B.

Cedarville, Ohio

"Allen always puts work before play, Reads and studies the whole, live-long day!

But the evenings, we've heard, This shy little "bird"

Spends on a farm $n$ t far away."

LUCILE JOHNSON, MUsiC

Cedarville, Ohio

"Lucile is both graceful and airy, She glides o'er the keys like a fairy;

When a song she sings,

Her voice trills and rings And warbles just like a canary."

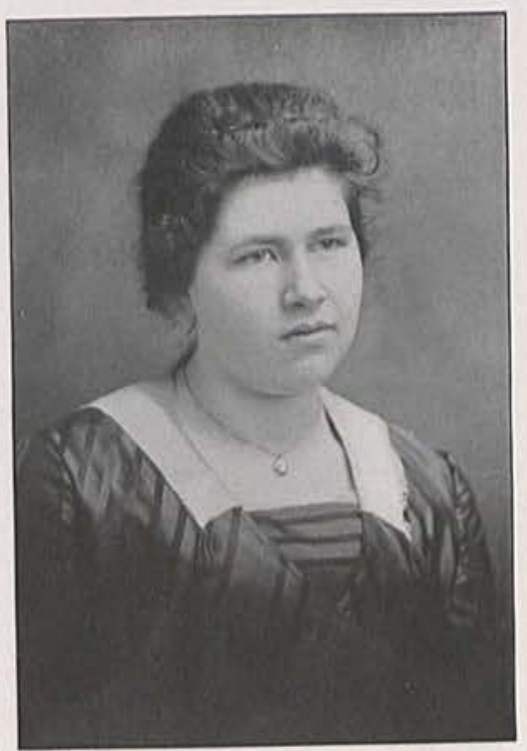



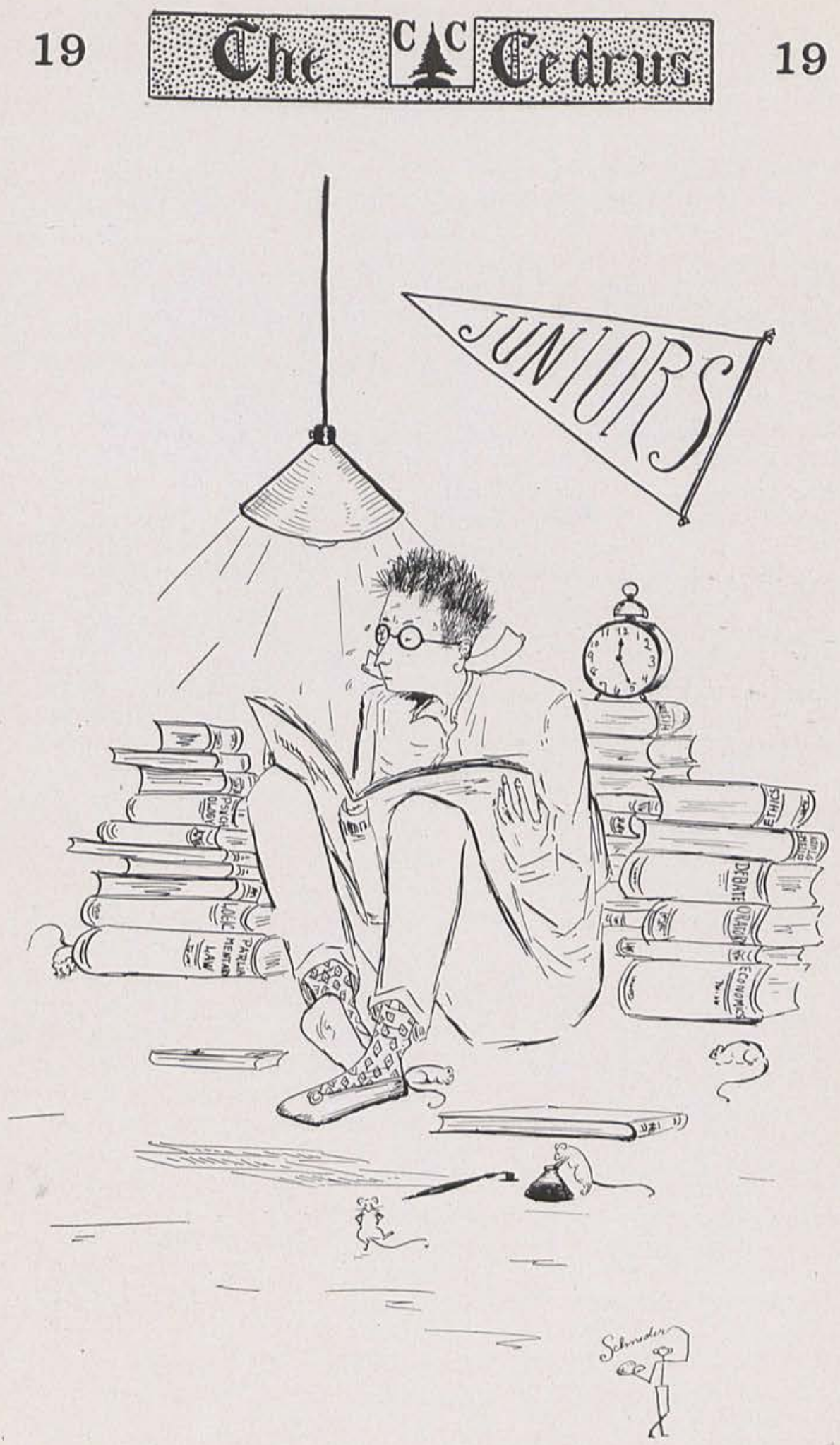


\section{SECRET THOTS OF JUNIORS}

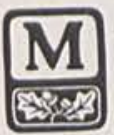

ANY times have our upper classmen sung our praises, but never have we really had the opportunity of telling you our modest opinion of ourselves. It makes us blush terribly to tell you some of these things, but nevertheless we are willing to blush if you will listen.

We, the self-possessed and respecting Juniors, were (if you can believe it) once green and awkward Freshmen. We, like you, my dear Freshies, stumbled into classes amid the laughs and grins of the upper classmen. We also had spreads and midnight raids by which we distinguished ourselves by painting our grinning mugs and initials upon the College entrance. And-the following morning we listened to an interesting speech by the President, who honored us by mentioning our names several times in his remarks. Those were gay times in our career, but long since have we put away childish things and have become men.

Our idea no longer is to bluff our professors as we did in that memorable Sophomore class (just ask them if you doubt it). They themselves will tell you that they are astonished at the answers which come from our mouths (for they cannot be recognized as coming from our brains). We (as you can see from our history) do not think as we did formerlythought we knew it all.

And now we are Juniors. In our estimation we are by far the greatest class in College. In fact (we think), the College would close were it not for our strengthening and uplifting presence. We may be small, but yet we are mighty.

We expect (if the professors see fit) to be dignified Seniors next year. Then, ah, then will we look down upon every one, for we will have accomplished our great mission in life (to graduate sometime). But although we may be dignified and stately, we will never forget our Junior year and the many spreads which we never had. And if you do not mistake the muddiness of this epitome for depth, you will conclude that the Juniors are the extraordinary beings that they are. Though I speak with the tongues of men and angels, and am not a Junior, I am become as sounding brass or a tinkling symbol. The Junior suffereth long and is kind; he envieth not; he is not puffed up; doth not behave himself unseemly; seeketh not his own, but that of some one else; is not easily provoked; thinketh no evil; beareth all things; believeth all things; hopeth all things; endureth all things. The Junior never "faileth"; but whether there be Freshies, they shall fail; and whether there be Sophs, they shall cease; whether there be Seniors, they shall vanish away. But the greatest of these is the Junior. HISTORIAN. 


\section{JUNIOR CLASS POEM}

We are Juniors of unusual fame,

And for ourselves, we've made a name;

We have been foolish in our younger days,

But experience has taught us to mend our ways.

We're Reba, Rebecca, Ellen, and "Dot,"

To be with the girls is Morton's lot.

Sink or swim, perish or survive,

That's the motto that suits us five.

Toiling, not for grades, but for love of knowledge,

We're the ideal class of Cedarville College;

Always zealous in play, and ambitious in work,

And the worth-while things we never shirk.

We are the survivors and the best;

We stay with the class and banish the rest.

Some took too little, and others too much;

With such folks as they, we don't keep in touch.

We will certainly not try to recite to you All the great things our members can do; With our great orator and musicians great It's easy enough to predict our fate.

Our "Mort" has been chosen speaker by all;

Now, is that an honor that's very small?

Sure, Ellen is just as great, "in a way,"

Since she tells the "orator" what to say.

What other class has been honored more?

Two chosen for a dance that consists of four;

They are so neat, so slender and charming,

They dance with a grace that's quite alarming.

And can't we be proud of our "Becky" so fair,

With her big brown freckles and auburn hair?

When she opens her mouth in that sweet way, to sing

The birds sit still and say never a thing.

Now, Sophomores, as you laboriously climb,

Be a little more careful of your time.

It's an honored place, we submit to you;

Please don't disgrace it before you are through. 


\section{9}
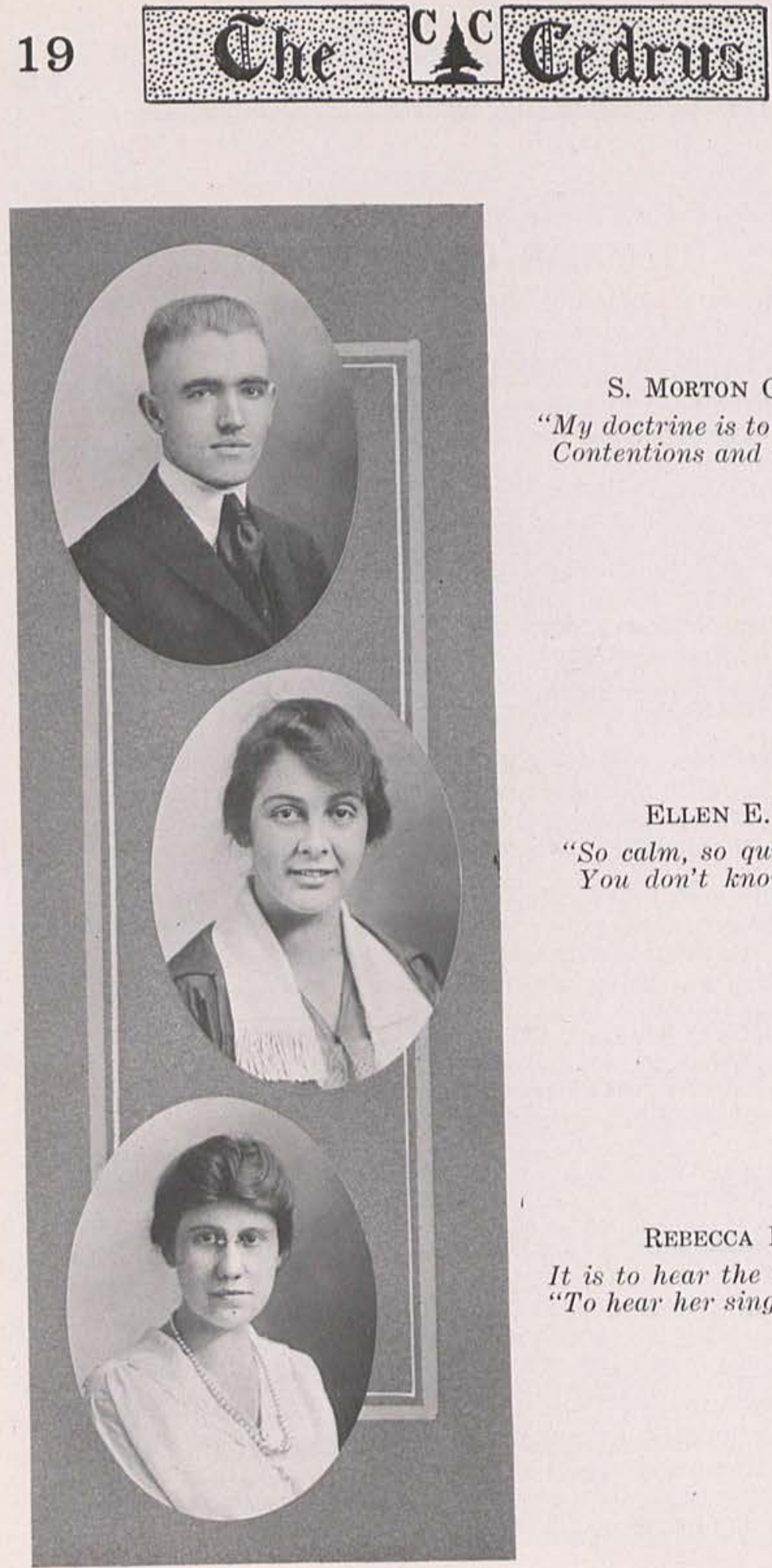

S. Morton Creswell

"My doctrine is to lay aside

Contentions and be satisfied."

ELLEN E. TARBox

"So calm, so quiet,

You don't know she's here."

REBECCA F. MARSH

It is to hear the birds of spring."

"To hear her sing-to hear her sing, 


\section{9 r.}

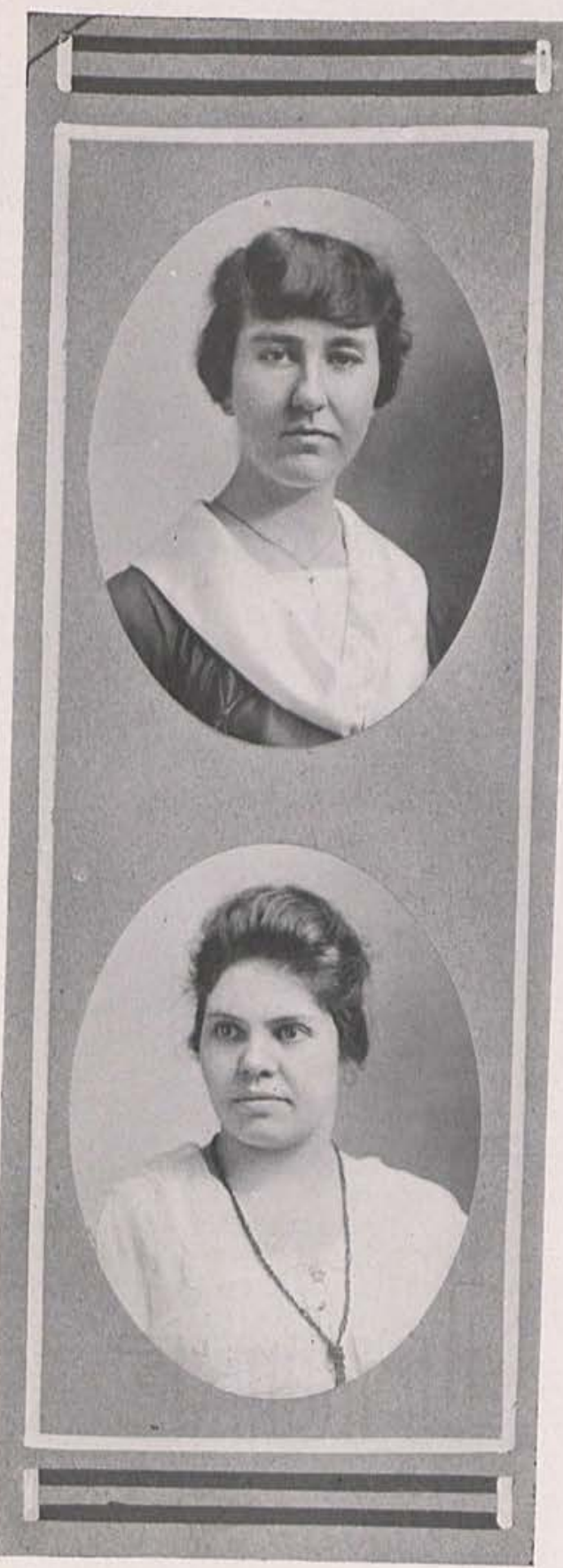

REBA I. HARBISON

"Lo, steadfast and serene, In patient pause between The seen and the unseen."

\section{DOROTHY SMITHSON}

"Cold Winter hath laid siege. Go, Winter, go thy ways.

We want again the twitter of the blue-bird and the jays." 


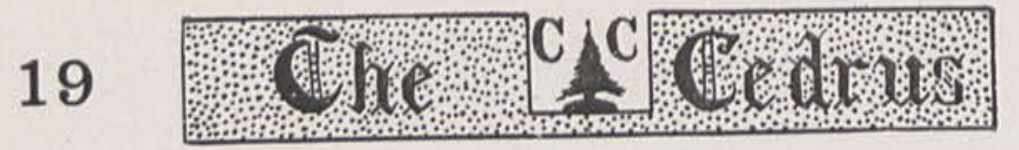

19

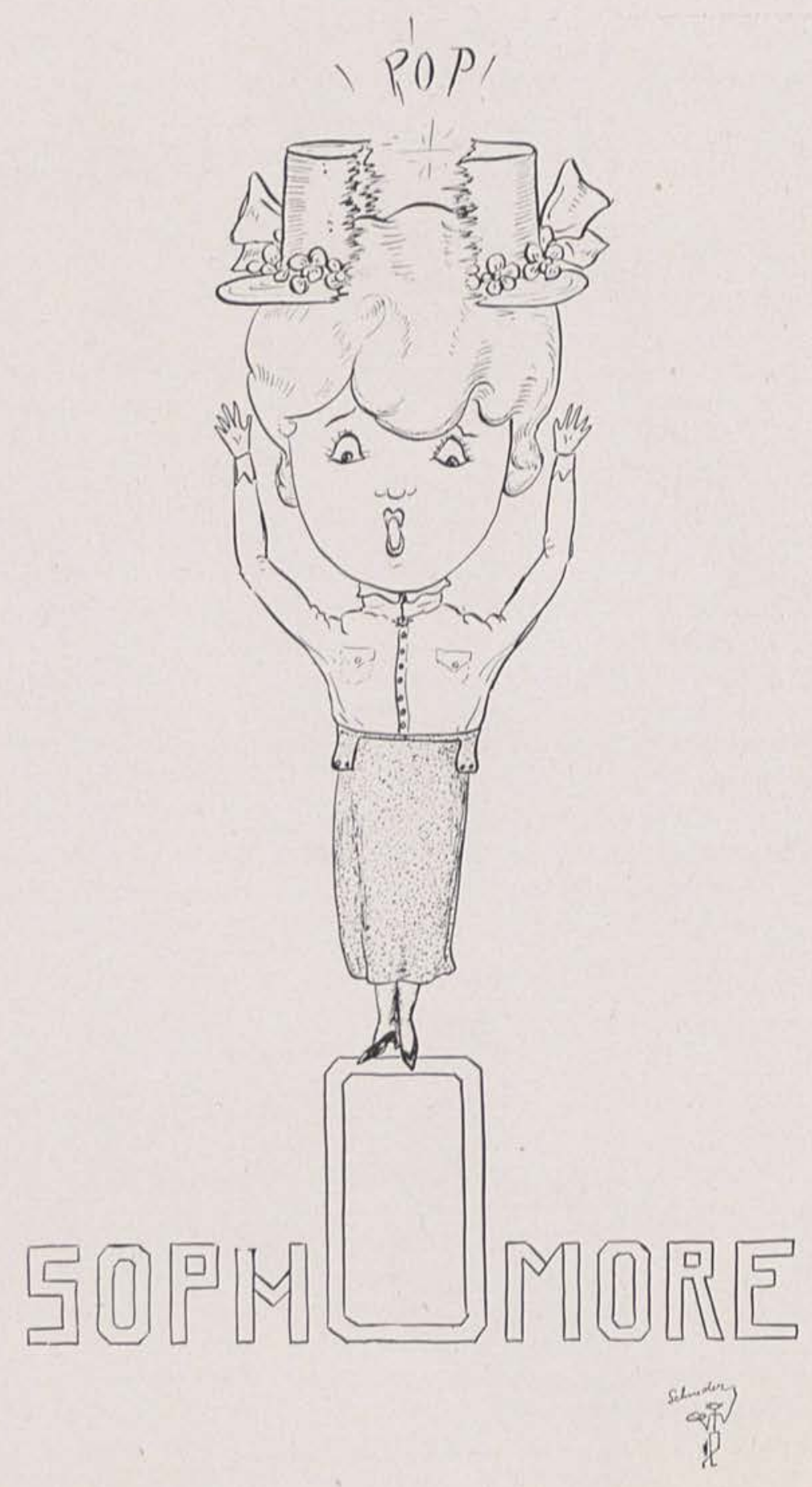




\section{9}

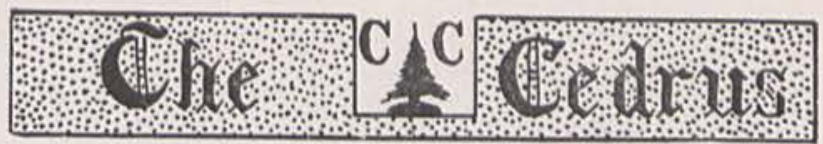

\section{HISTORY OF THE SOPHOMORE CLASS, '21}

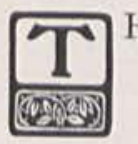

HE skies wept for two weeks, unceasingly and mournfully, after September 11, 1918. And what wonder! The class that had been Freshmen in '17 were Sophomores in '18. The faculty sympathized with the skies, for they began to realize that there were only three more years to be spent in the company of the distinguished class of '21. The Seniors were blue because they were not Freshmen so that they would have the privilege of longer enjoying the company of the class of '21. The Juniors went about with regretful faces wishing they had remained out of school another year and thus have the honor of graduating in the class of ' 21 . Even the poor, scared, little Freshmen felt worse because they had missed the class of ' 21 . The Sophomores alone remained cheerful amid all this woe, because they were perfectly satisfied to be just what they were.

After two weeks things began to clear up. The faculty began to realize that, "although blessings brighten as they take their flight," the best thing to do is to enjoy them ere they flee. The Seniors, Juniors, and Freshmen decided that if they could not be Sophomores in '18, they would do the next best thing and enjoy the Sophomores' company. And the sun began to shine.

Then you should have seen those Sophomores dig! No, they didn't grind. They were studious, yet a lively bunch. In the course of a few weeks they held a class meeting and the girls gave the presidency to the sole and only "Lord of Creation" in the class, Harold Hammond, of Industry, Pennsylvania.

But, alas, in this life not even Sophomores' lives sail smoothly along. Not many days passed before the class gathered at the home of one of the most studious and reliable girls in the class, Helen Stewart, of Wilmington Pike. The purpose of this gathering was to bid farewell to their secretary, who was leaving college to take up life in Philadelphia, Pennsylvania.

Harry Wright and Nelson Thorne, former members of '17, having served their country, the former "over here," the latter "over there," were received again into the class with much rejoicing mixed with pride.

Soon trouble came again. Ida Rees, jolly, good-natured Ida, from Camden, Ohio, had to return to her home in the middle of the school year. Ida could not remain away, however, and returned to be a Sophomore again. Eva Liming, who only spent a short time with the class, left about this time for other pastures.

In their moments of grief, the class was cheered and uplifted again by the entrance of another member. This time it was Paul Duncan, of Darlington, Pennsylvania, a Junior, who wishing to be nearer the Freshmen, joined the Sophomore ranks.

Then, what a spread at Bob Edwards'! What eats they had! How the Freshman paid them a visit and were forced to admit the Sophs were kindhearted, after all!

It would be impossible to cram into few words the doings of these Sophomores. This is but a brief résumé, and "the half has not been told." 


\section{SOPHOMORE POEM}

It little profits a poet born

To sit and think and blow his horn,

Telling of the dceds of Sophomore days,

When certainly each one knows our ways.

But lest we forget, it is good and well

On Sophomore works for a while to dwell;

So get your knitting and have a seat,

While you learn of a class that can't be beat.

There is Louisa Greer, a Pennsylvania lass;

She was never known to cut a class;

But she often dreams about "the farm."

Says she, "Short boys are surely a charm."

Miss Rees of our class, charming and fair,

Was anxious to help Uncle Sam "over there,"

But the armistice put out the light of her hope

Of going across seas in a big steamboat.

Miss Stewart, the girl divinely fair-

She is always smiling, knows no care;

She is fine in class, never plays hook

Since friends and good times she finds in a book.

There is our New York boy, Nelson Thorne,

Who for good deeds was only born;

He was overseas, and helped lick the Hun;

$\mathrm{Ah}$, a fine soldier! He never knew run.

Paul Duncan, our little energetic preacher,

Is much interested in a pretty school teacher;

Paul is our devoted Seminary lad,

He never believed in doing anything bad.

Among our boys who heard Uncle Sam's call

Was Harry Wright, fair and tall;

He joined the Colors in the S. A. T. C.

Would that we were all happy and joyous as he!

Now, the composer of this work is surely some poet;

With a little hair on his chin, he would make a

$$
\text { fine "goet" (goat). }
$$

-D. H. H. 

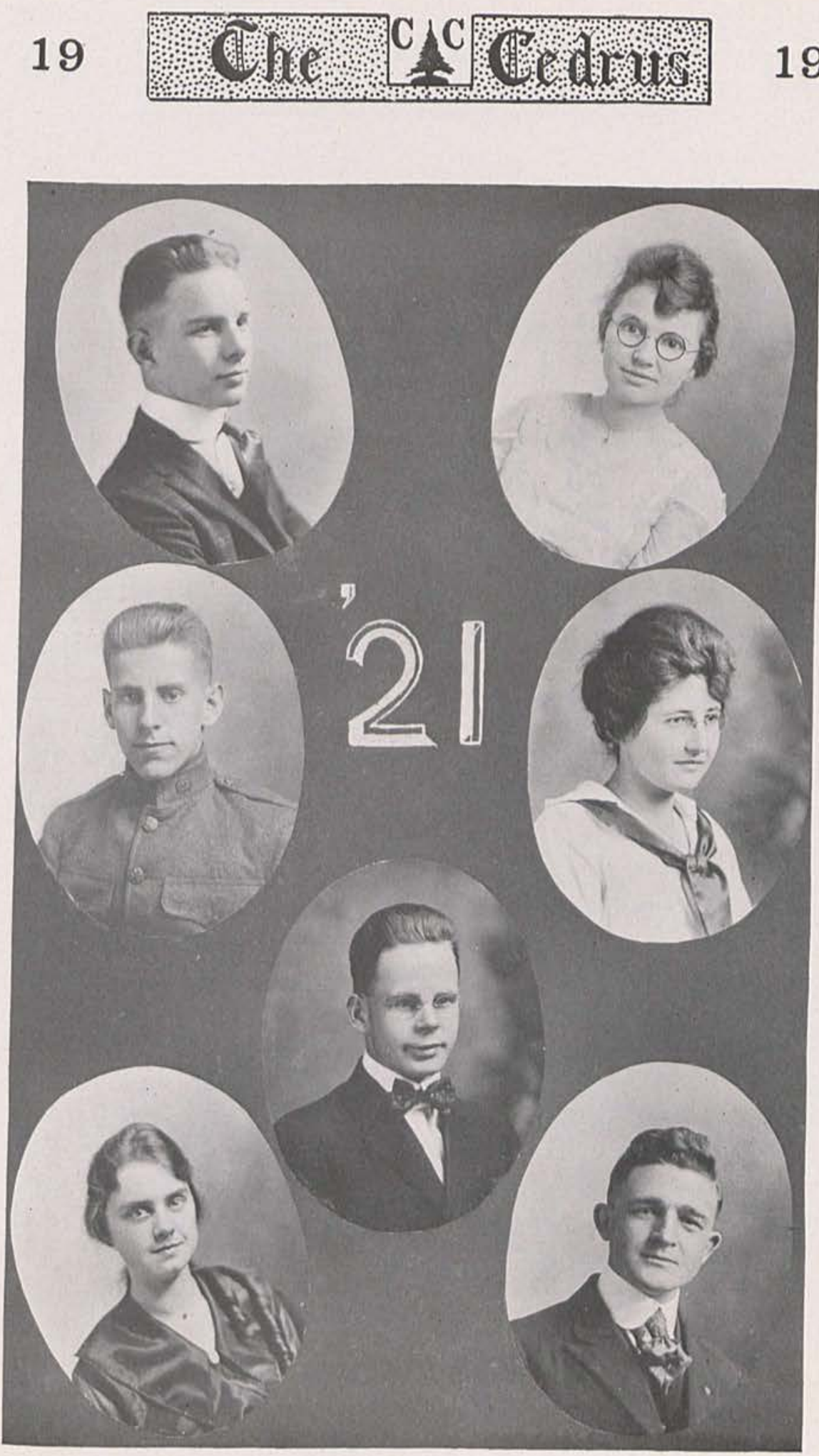


\section{9}

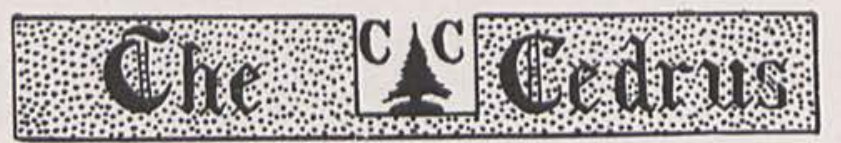

19

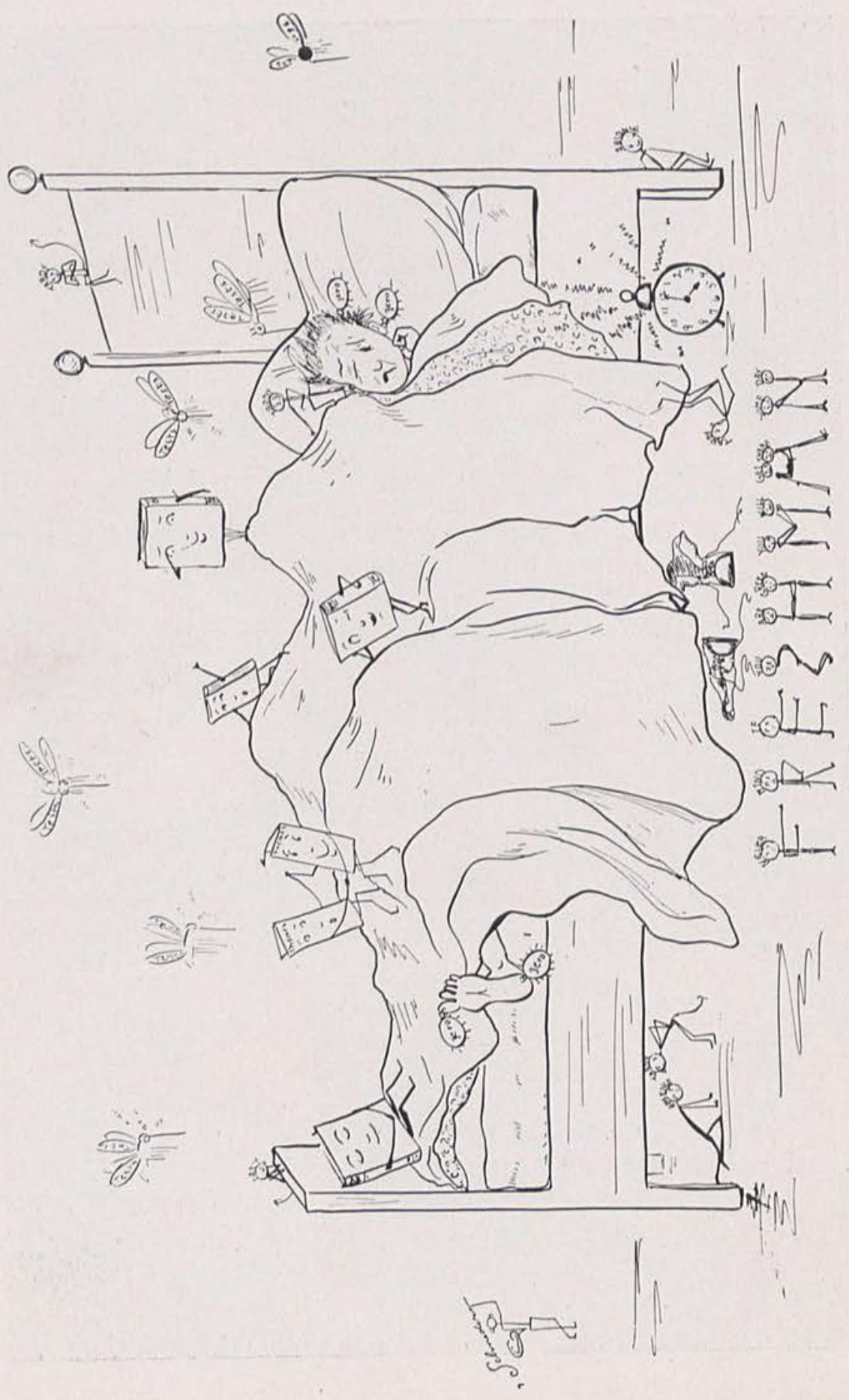




\section{9}

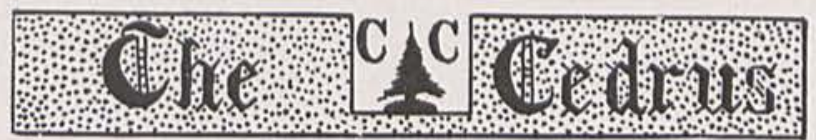

\section{FRESHMAN HISTORY}

T IS exceedingly difficult for historians to write concerning their own age. They cannot place events in their proper relations nor do they get the true perspective. So events which seem commonplace enough now may in later years be viewed as turning-points in history.

We may have been green when we first stepped into the halls of dear old Cedarville College, but in the place of the customary bright and glowing shade, injurious to eyes and understanding, we were the young, shooting green that holds out the promise of great growth, and in one year we have demonstrated that we have taken firm root, are fulfilling our early promise, and have already accomplished many achievements of note.

When we entered, it was with the desire and determination that might proclaim a new day had dawned for Cedarville College, and the new class within her gates was continually stretching up ambitious fingers to clutch at the glory in every field. However, we have never been lacking in the austere curriculum of the school's activity from athletics to studies. As individuals we have even greater distinctions; in number of athletes, debaters, orators, and fussers, we stand without peer.

The literary society finds its most energetic, loyal, and willing members among the Freshmen and we are proud of our scholastic record. Our career in the circles of polite society has not been neglected, as you have seen. But we will not boast for ourselves individually, but man to man and woman to woman, where can you beat us? Remember, Freshmen of today are Seniors of Tomorrow.

Whatever we may have accomplished as a class, may be attributed to our unanimity of purpose. We have pulled together at all times. Our watchword has been that time-honored phrase, "United we stand, divided we fall."

We've quantity and quality together,

To bring our class through all kinds of weather.

-R. F. I. 


\section{FRESHMAN POEM}

Ye people who these pages chance to turn,

Pause for a moment, fix your peepers here;

Read of the valorous deeds our class has done,

And henceforth look on us with awe and fear.

Look first on Ernest, he of noble mien, In deeds of bravery he is never last;

Once with his car he chased an enemy

And raced across the campus dark and vast.

Then Tacy, comely maid, divinely tall, Bought all the powder in the village store,

And used a pound or two day after day, And now she weeps because there is no more,

There's Cecil, handsome youth of tender years; In grace and manners he surpasse 3 all;

Although he always studies earnestly, His great ambition is to grow quite tall.

Our brother Insley has become inspired Since he has lately sailed the deep blue sea;

The ladies like him very, very well. Hence he is happy as a lad should be.

Day after day "Joe" urges us to come And climb with her to wisdom's dizzy reak;

Farewell, dear one, we wish you all good luck; We cannot go-our carriages are weak.

Fortune has favored Edwin most of all. He is the greatest of our little band;

If you have ever seen this happy boy, You know that he is destined to expand.

Our Margaret is a winsome little moid. A joyous, shv, and unassuming child;

She loves her Latin and adores her French, About her Rhetoric she is simply wild.

Once Robert thought it policy to buy Some chocolate sweets for his best lady friend; He put them in his room and, sad but true. They disappeared and no one knows their end.

We are quite fond of our Kantucky maid. Our Calla from the land of briers and burs;

She looks the whole world in the face and smiles; Would that we all had hearts as true as her ?

For Edith has a light and fickle heart, As changeful as the dews of tinted morn;

For each new conquest o'er some gallant youth She leaves a heart all saddened and forlorn.

I know not how we'd manage without Ralph; In French he ever is our beacon light;

Twould touch your heart to hear him raad in French; His motto seems to be, "Keep up the fight."

Kind providence has given us Louise

To keep us all from growing old and sad,

From basking in the light of midnight oil;

Child of our hearts, you make our dark hours glad.

Ye people who have fixed your peepers here And find the meaning vague or hard to see,

And so cannot appreciate our class,

For explanations come to L. A. D. 

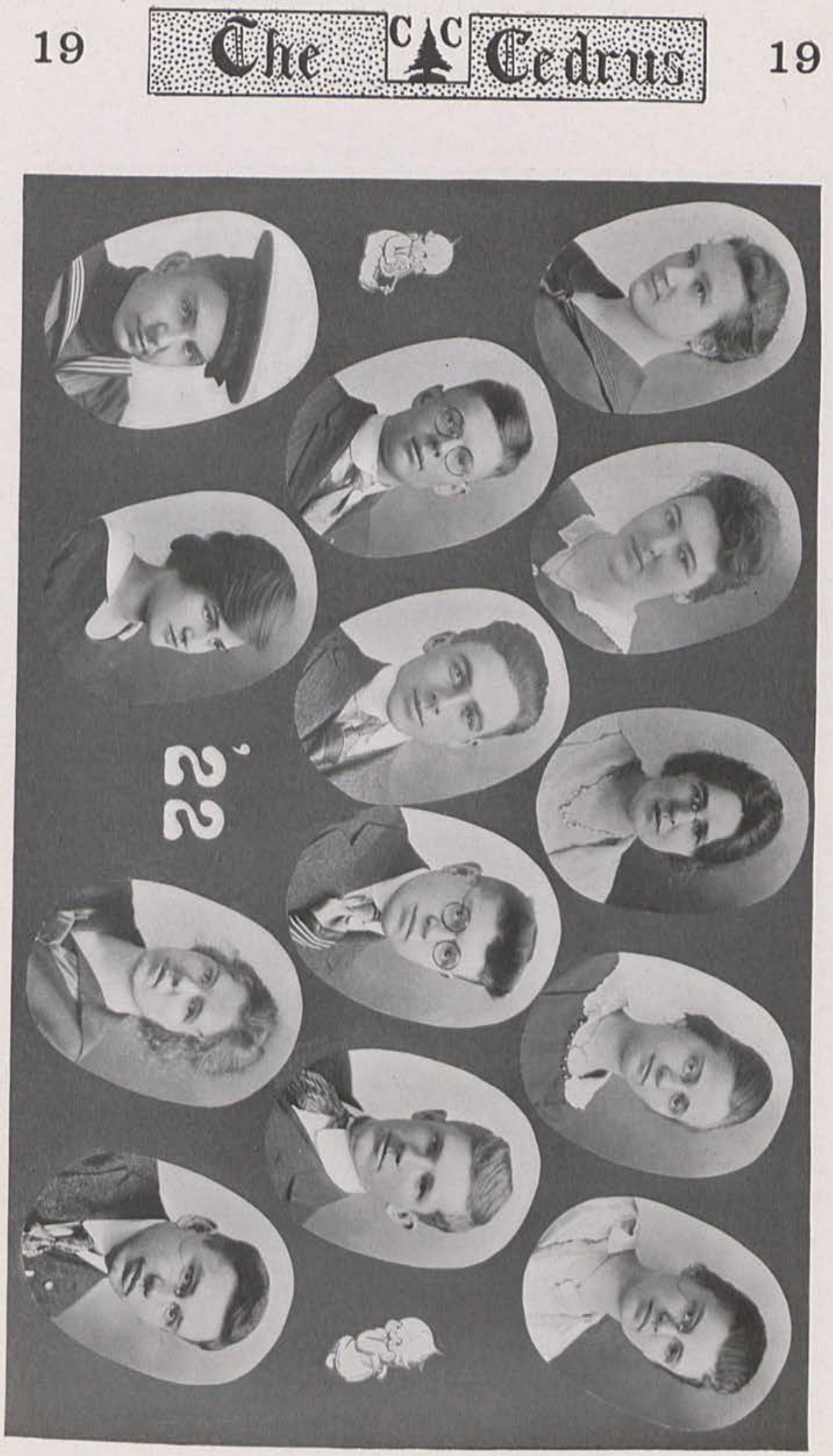


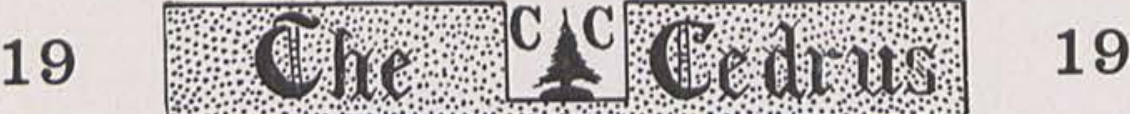

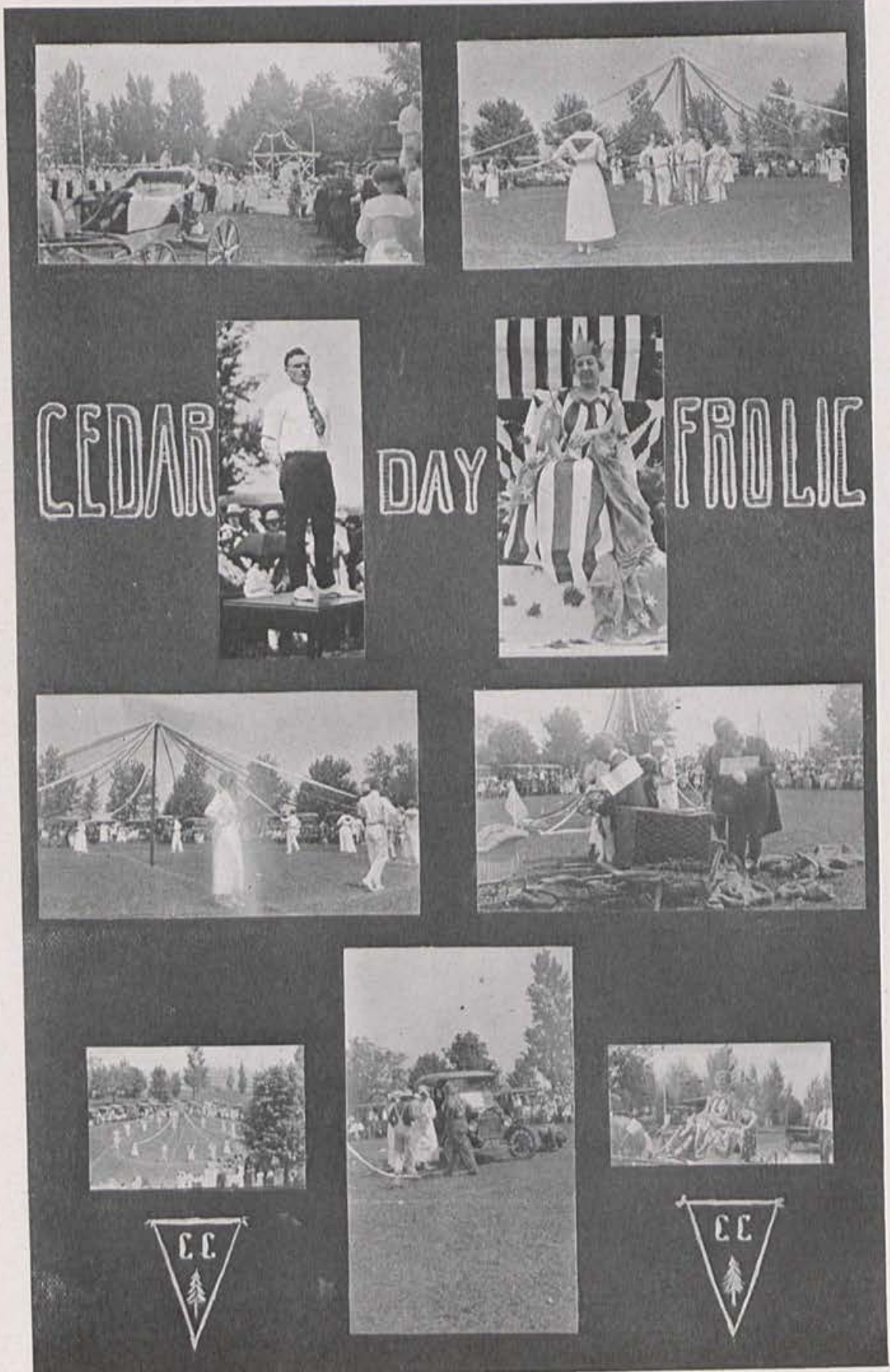




\section{9}

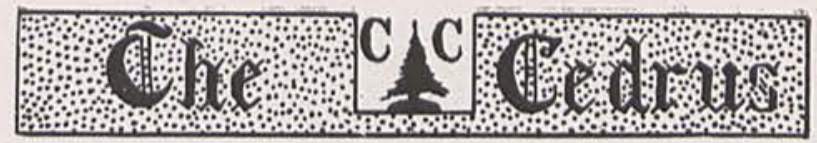

19

IN MEMORIAM

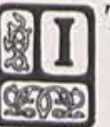

T IS fitting that we should remember upon his birthday WALLACE COOPER ANDERSON, youngest son of William and Emma Anderson, who was born near Xenia on February 7, 1898, and was killed in an accident at sea near Pensacola Naval Air Station on October 30, 1918.

The early part of his life was spent near and in Cedarville, and those of the community here sincerely mourn his untimely death. After a year spent in Cedarville College, he went west to join his brother, and there entered Cooper College in Sterling, Kansas. It was while in that institution that the call of his country came to him so strongly that he volunteered his services in the navy. For two months he was at the Great Lakes Naval Training Station, thence was transferred to the Pensacola Naval Air Station where he served during a period of four months until his death.

Friends here and in the service unite in expressing their appreciation of his character and influence. We of Cedarville College point with mingled pride and sorrow to the gold star on our flag which symbolizes the sacrifice of a loyal and unselfish youth to the cause of country and of humanity. At the time of Wallace Anderson's enlistment, the president of his college spoke to him seriously of the dangers attendant upon the service into which he was going. His answer showed a spirit of which his parents and friends may well be proud. "If Christians," he said, "have not the courage to give up their all for the sake of right and justice, who will!" In his death we see exemplified the great principle of sacrifice even to the uttermost, for the sake of righteousness and Christianity. His friends in the United States service respected his quiet, but none the less firm, Christian convictions, and admired the qualities of his character. "We shall miss Wallace from our midst," writes his chaplain at Pensacola, "and are proud to have known him. He was a lovable character and a loyal man who willingly gave his life that justice and righteousness might remain on earth." Another friend says of him, "He was a thorough student of the Bible. As we talked together man to man, I know his life was pure and his ideals high."

Wallace Anderson has gone home, but his ideals and influence still live in our midst. In his calm preparation for whatever might befall him, and in the tragic suddenness of his death, he left a message of inspiration to all who knew and loved him. "Taps" has been sounded above his grave, but his spirit still lives.

"Like the day star in the wave

Links a hero to his grave Midst the dew-fall of a nation's tears:

Happy is he o'er whose decline

The smiles of home may soothing shine And light him down the steep of years;

But, oh! how grand they sink to rest

Who close their eyes on Victory's breast." 


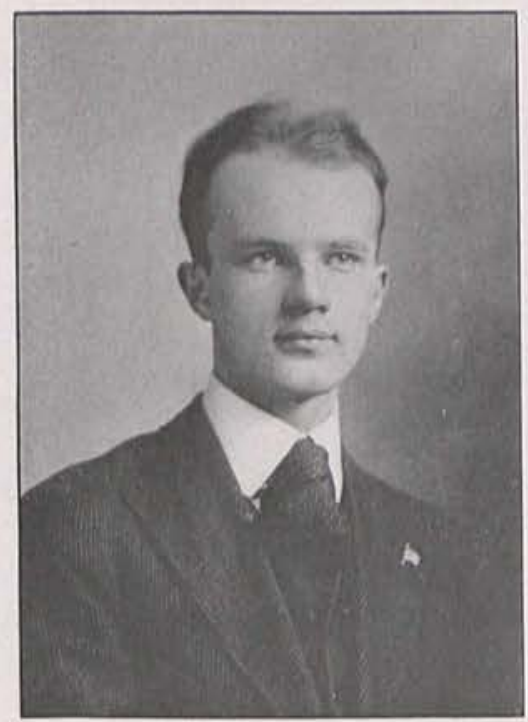

Paul James Elwood, son of Mr. and Mrs. Thos. Elwood, Atlantic City, N. J., was born in Philadelphia, Pa., October 13, 1897, and died in Cedarville, Ohio, October 18,1918 . The cause of his death was influenza.

Paul received his training prior to coming to Cedarville College in the public schools of Philadelphia and in the Atlantic City High School. When he died, he was in the third year of the Arts-Theology course of this institution.

He was a true type of a Christian gentleman. His motto was "Service," being willing to do all in his power to help his fellow men.

Our sympathy goes out to his parents, brothers, and sisters, who are left to mourn his loss. We feel his loss keenly.

"Oh, for the touch of a vanished hand, And the sound of a voice that is still." 


\section{9 - - 19}

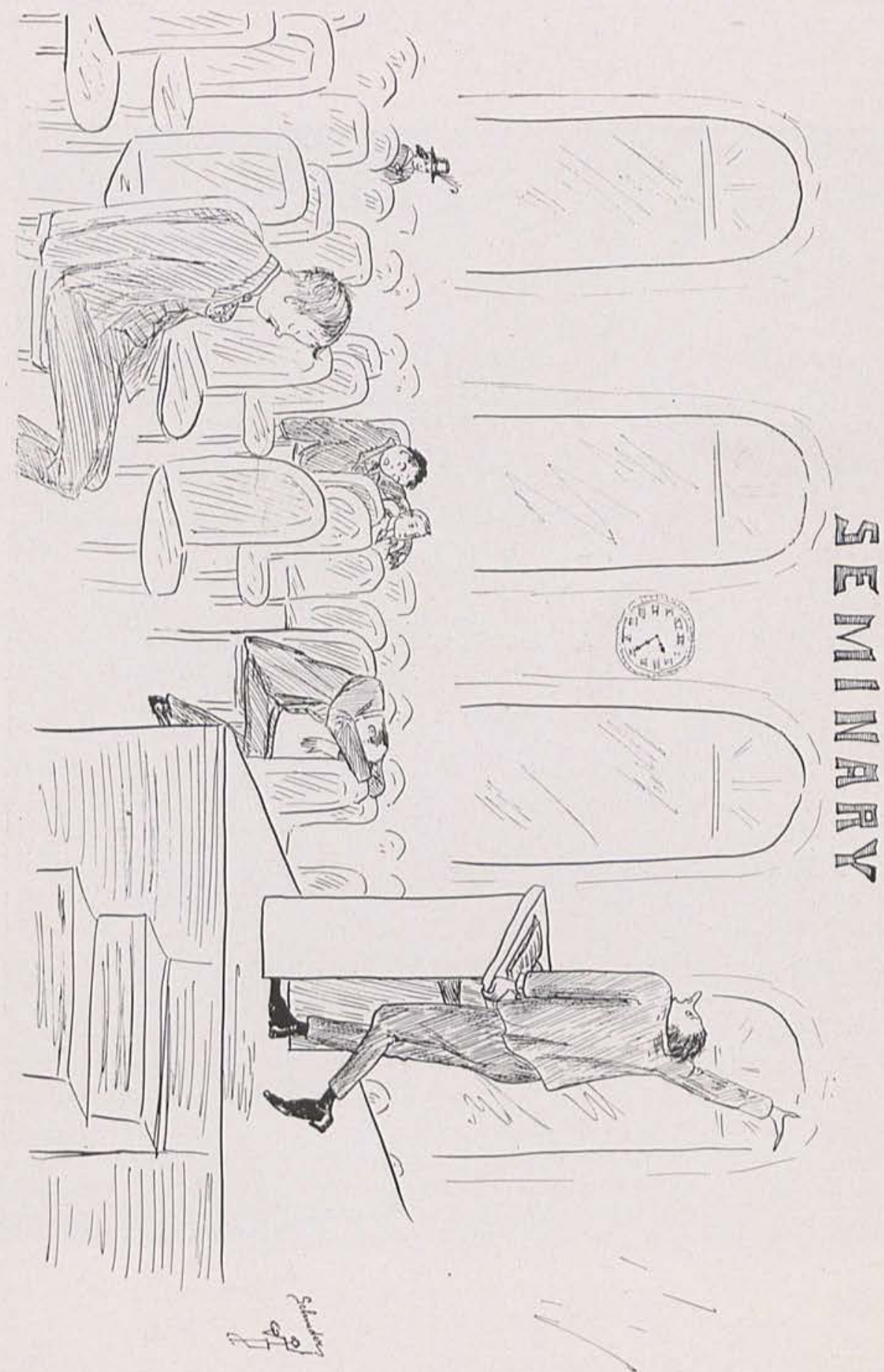



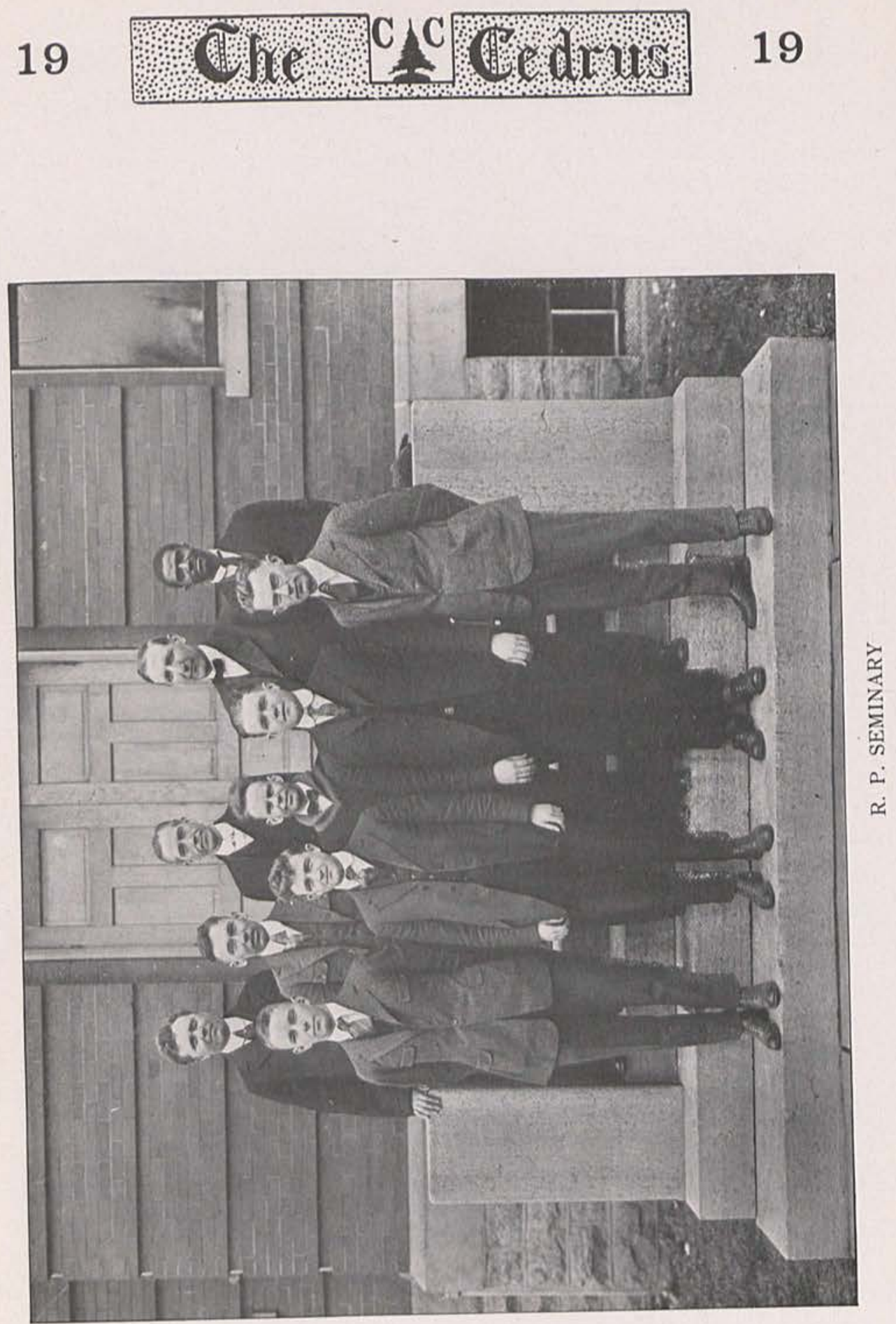


\section{9 ry r. 19}

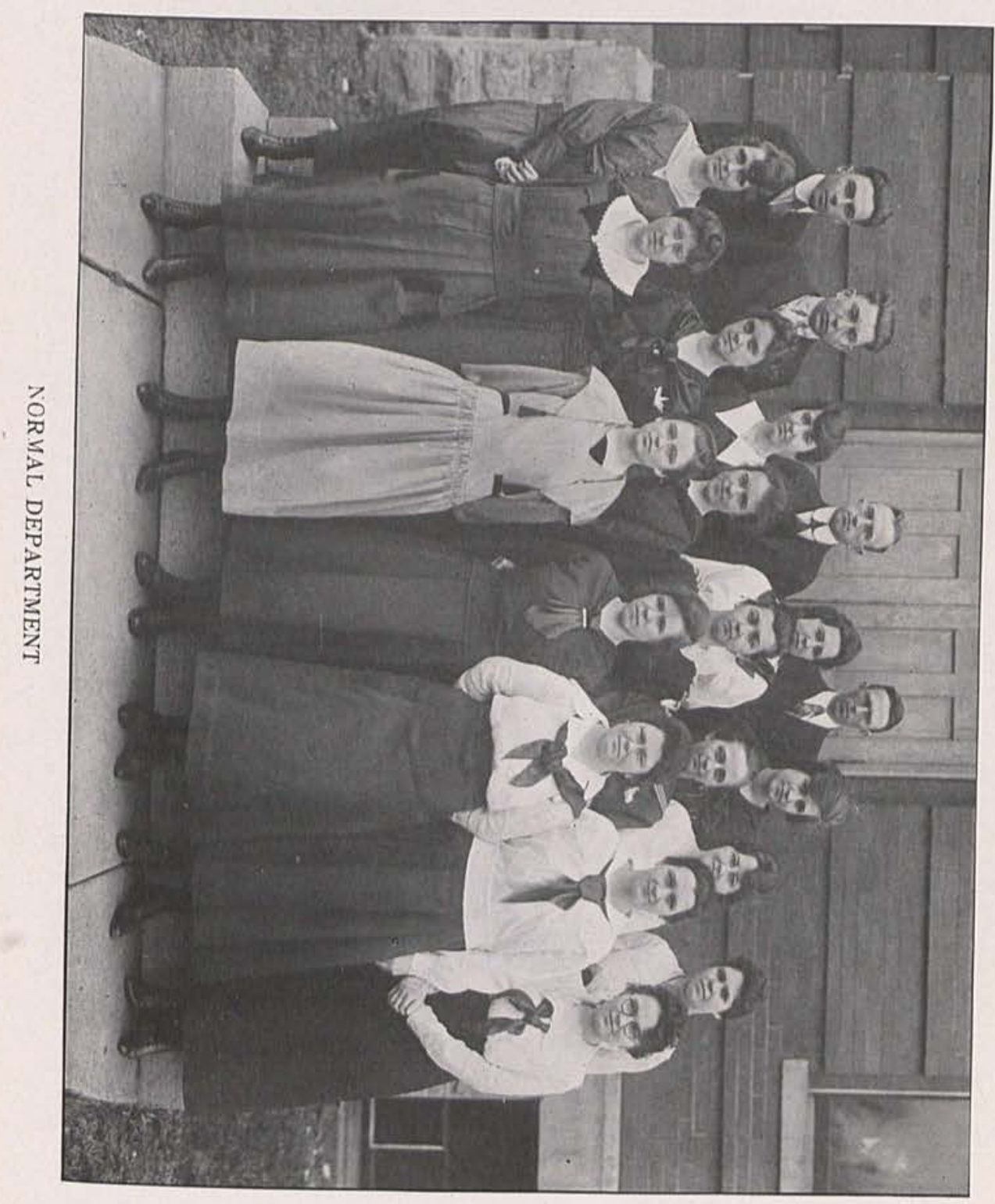




\section{9}

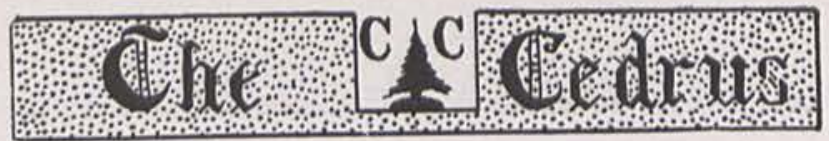

\section{CHAPEL LECTURES}

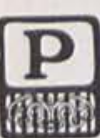

ROFESSOR ALLEN is extremely fond of delivering lectures in Chapel. However, we are forced to admit that our beloved professor does not have the high aim of benefiting the students in view during these lectures. We cannot deny that his aim seems to be entirely utilitarian. To prove our statement, we quote the following lectures:

\section{PREPAREDNESS}

(Given in the Spring of 1918)

"These are stirring times, momentous times; the world has never seen such conditions as exist today. The call of the nations of the world is men. They must have men to fight their battles and to carry on the industries at homs. Our Government has now entered the great war and is calling for men. Thousands of men are enlisting, yet the demand is greater than the supply. There are not enough men enlisting and the government finds it is necessary to draft men to serve in the army. So today I wish to draft a number of students to assist me in sending out some literature for the College. All those who are willing are drafted to come to the College this afternoon. Many hands make light work."

\section{A CURE FOR NERVOUSNESS}

Having talked to the students early in the spring of 1919 concerning the possibility cf meeting their fate if they would assist in preparing literature for the mail, it seems that not only the sudents went that afternoon to meet their fate, but most of the faculty were there also. All were married except one, however. Then one bright spring day we heard this one:

"I desire to lacture to you this morning on nervousness. It is true that you may become nervous by studying too much and keeping late hours. Some of you students have need for such a lecture as I wish to give you this morning. I can begin my lecture best by telling a story.

"A young man went to a hotel one evening to secure a room. He was told by the proprietor that all rooms were taken. The young man, desirous of securing a place to rest that night, asked the proprietor if he could not fix up a bed for him some place. The proprietor replied that he had two vacant rooms, but that a nervous old man had paid for three rooms, and desired one on either side of him vacant, so that he could sleep without being disturbed. Finally, the young man persuaded the proprietor to allow him to sleep in one of these rooms, provided he would not make any noise. The young man went into the room as quietly as possible, but after removing his shoe allowed it to drop heavily to the floor. He was very careful and placed the other shoe down lightly. As he was about asleep, he heard his door open and the nervous old man said, 'When are you going to drop the other shoe? You are nearly driving me crazy waiting for the other shoe to drop.'

"So it may be with you students. Some time ago, I asked you to help address some envelopes. Then I told you that I would need your assistance later. You are probably becoming nervous waiting for that other shoe to drop. So to prevent your becom ing nervous, I am glad to say that I desire as many as can to come to the College this afternoon and we will try to find work for you." 


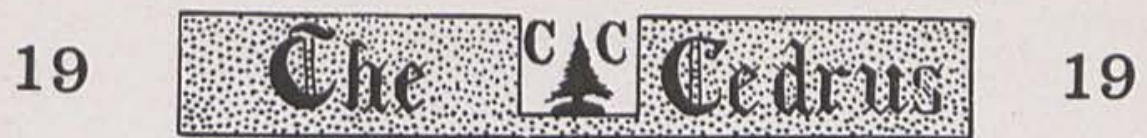
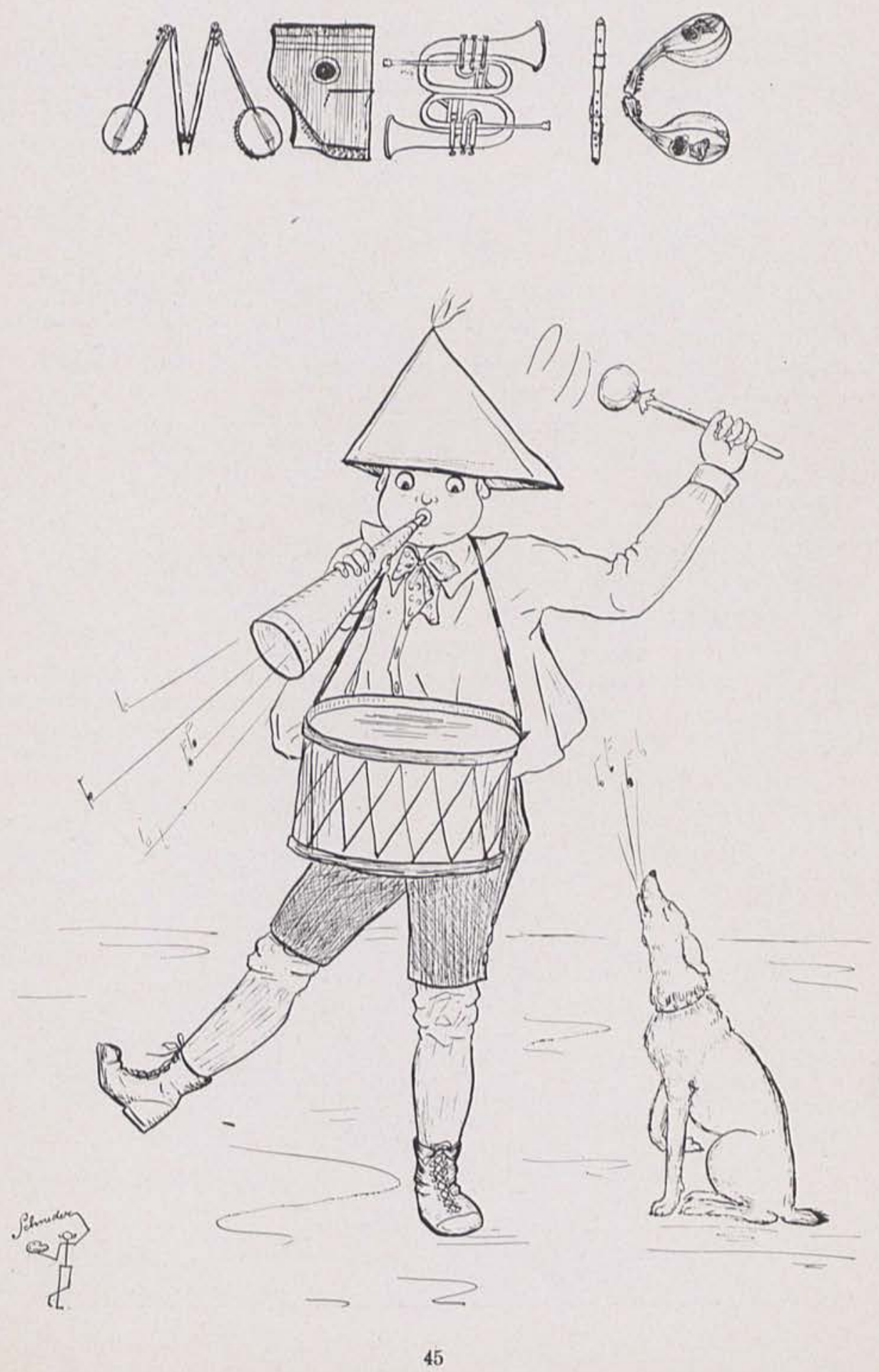


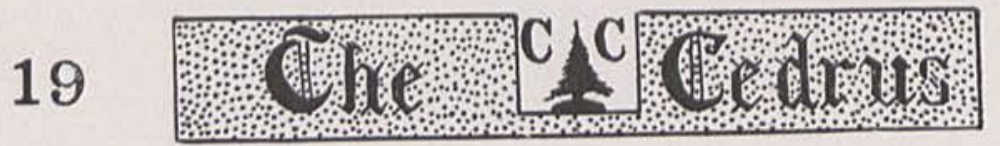

19

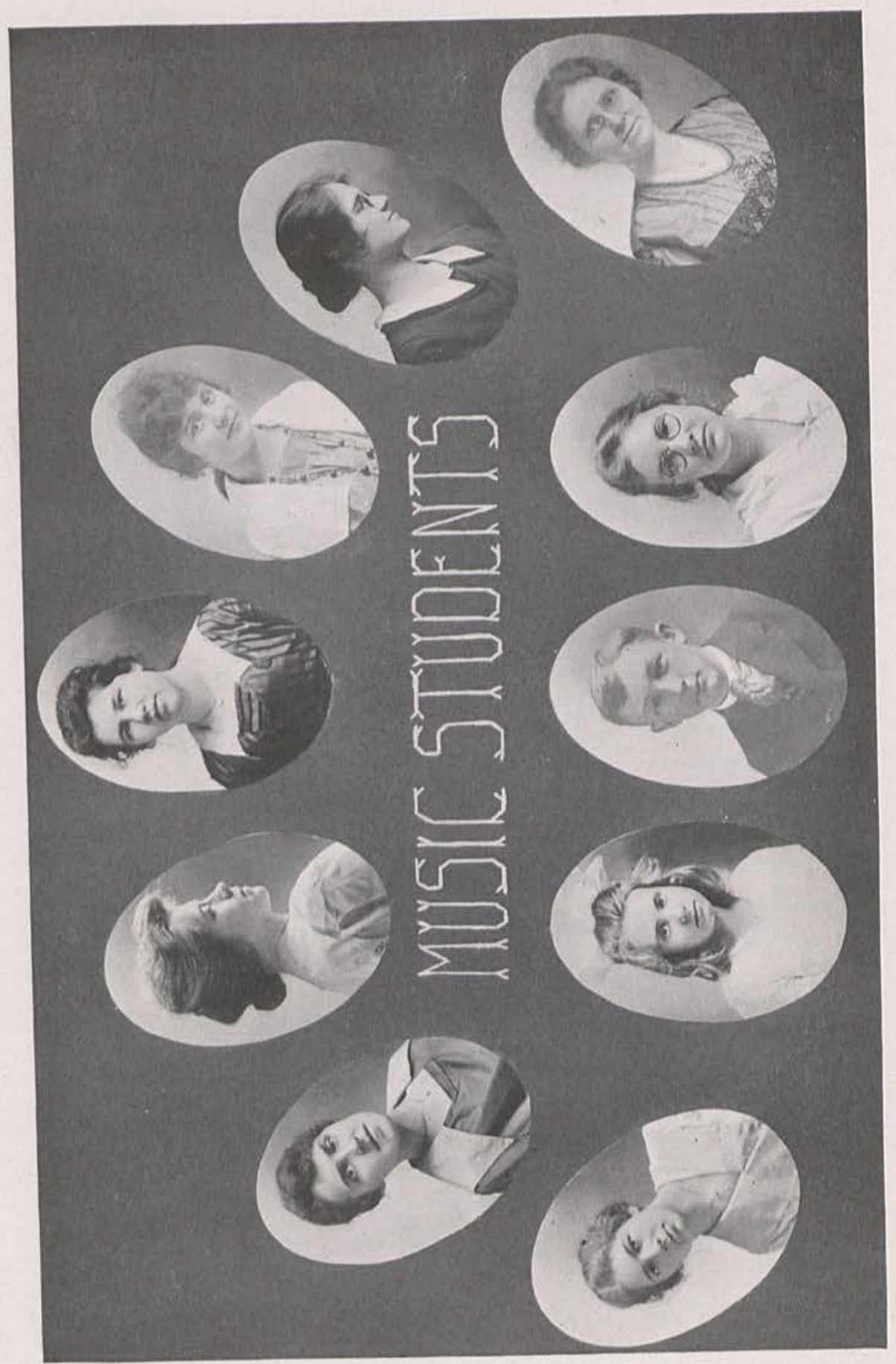




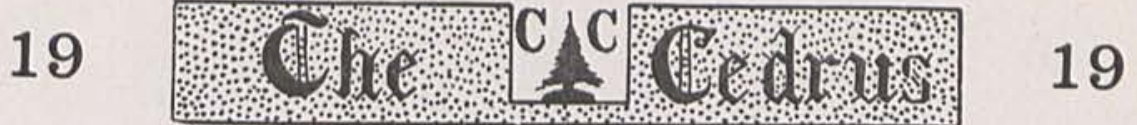

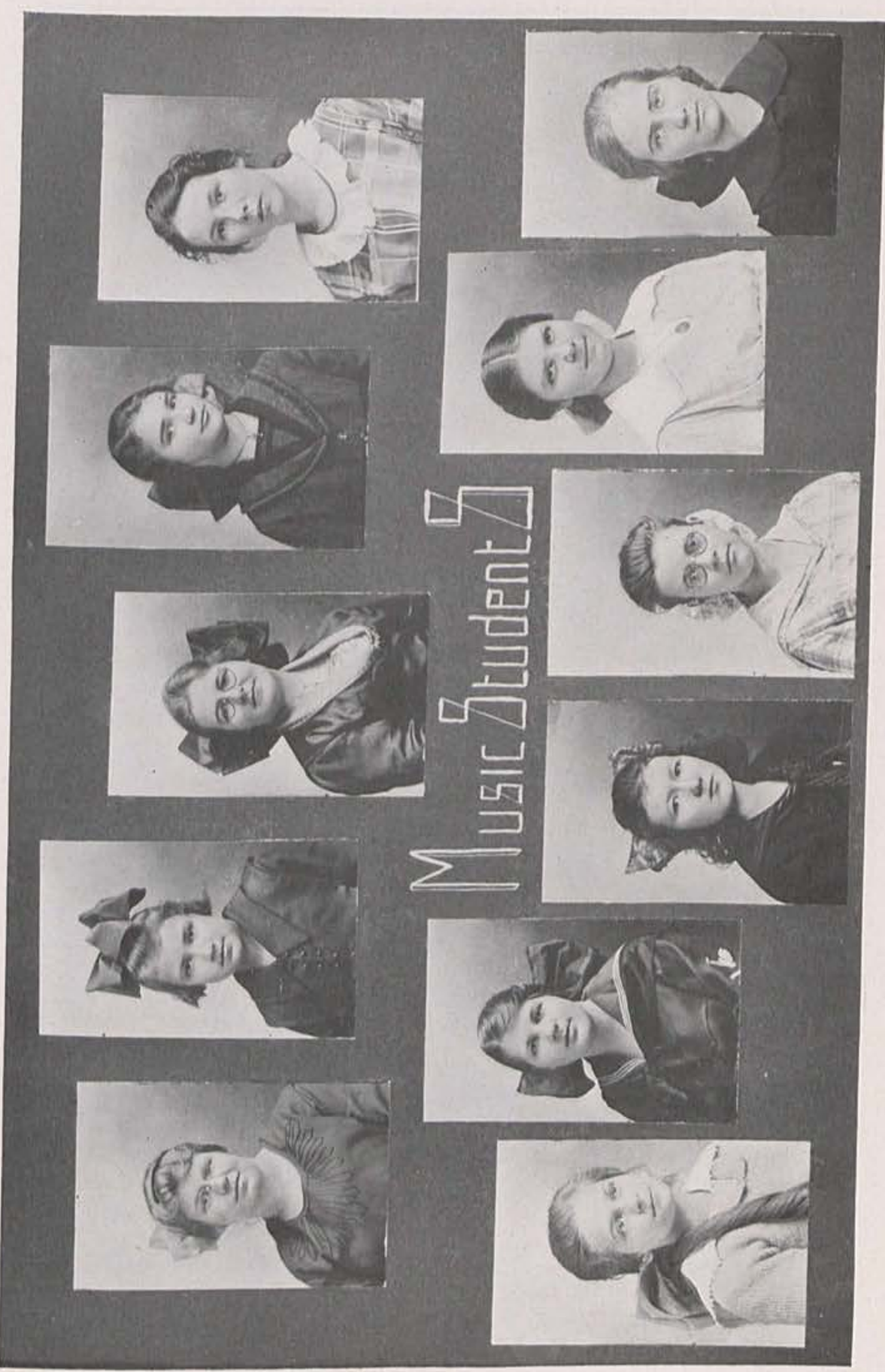




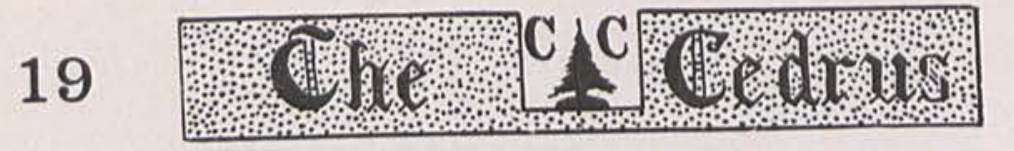

19

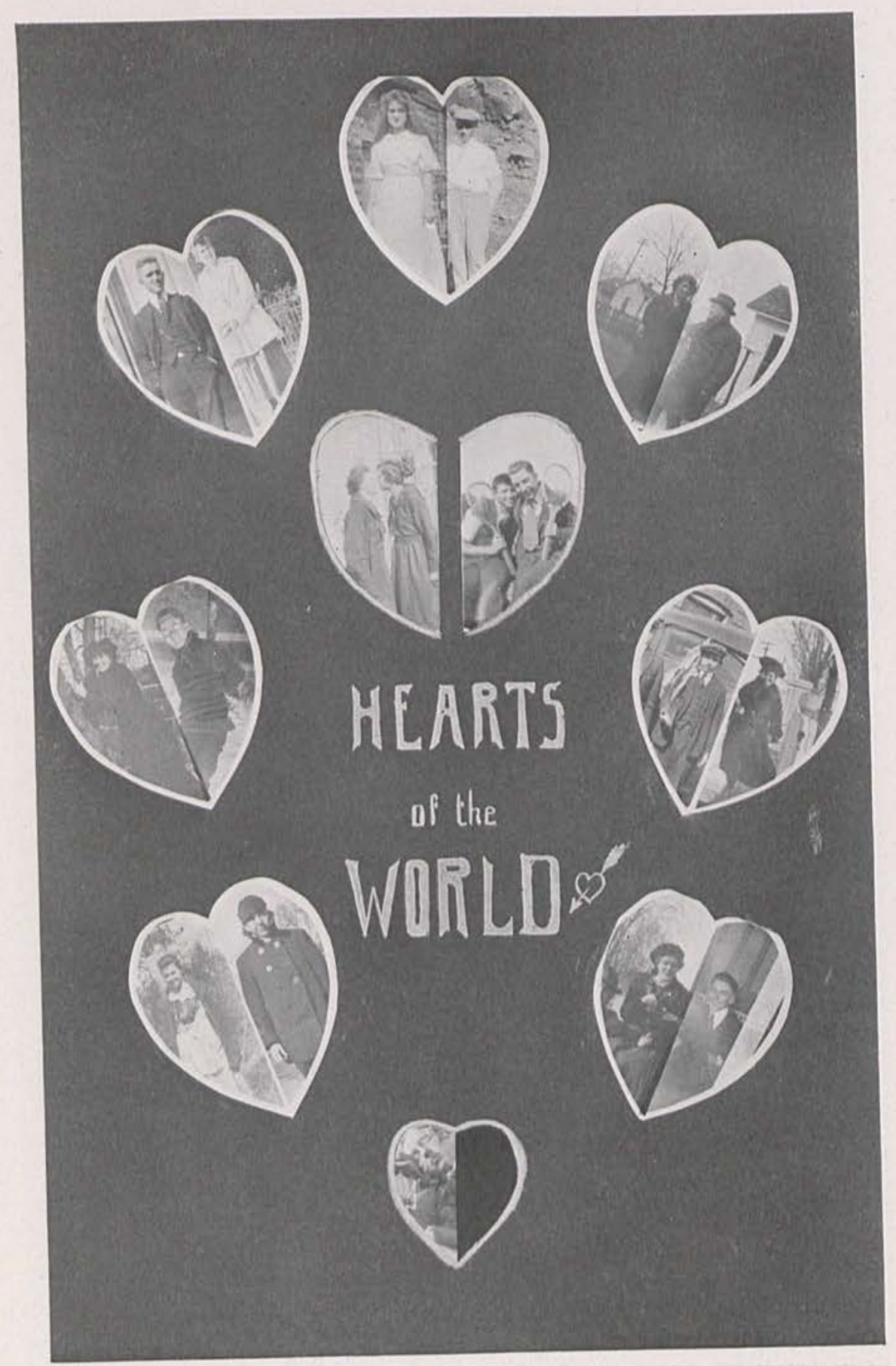




\section{9}

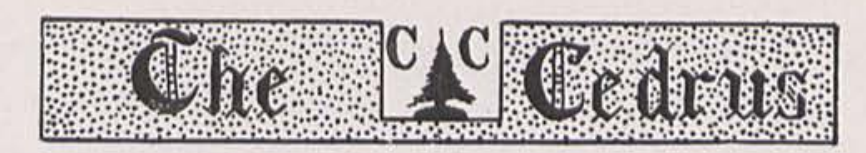

19

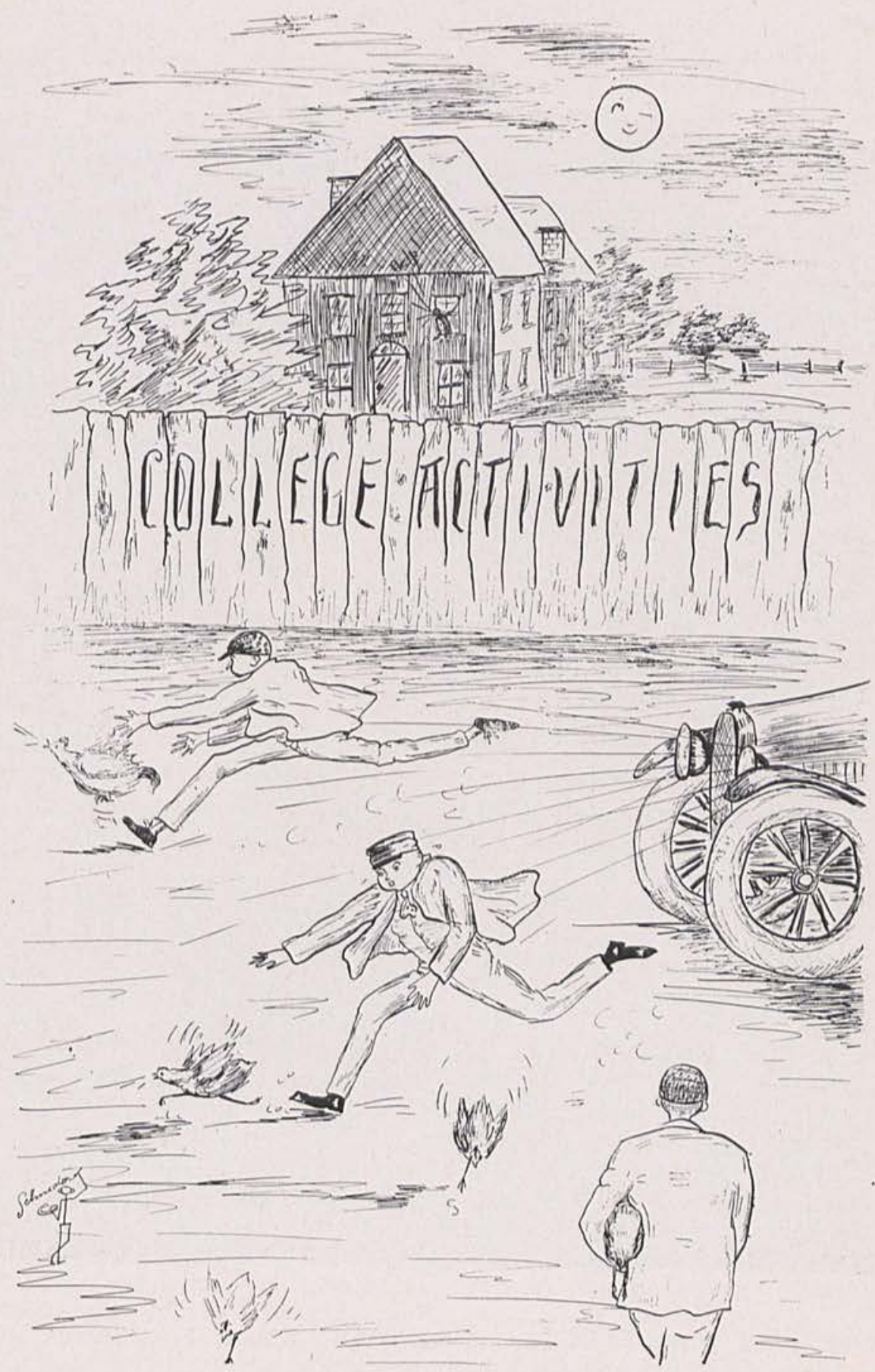




\section{9 mac.6C) 19}

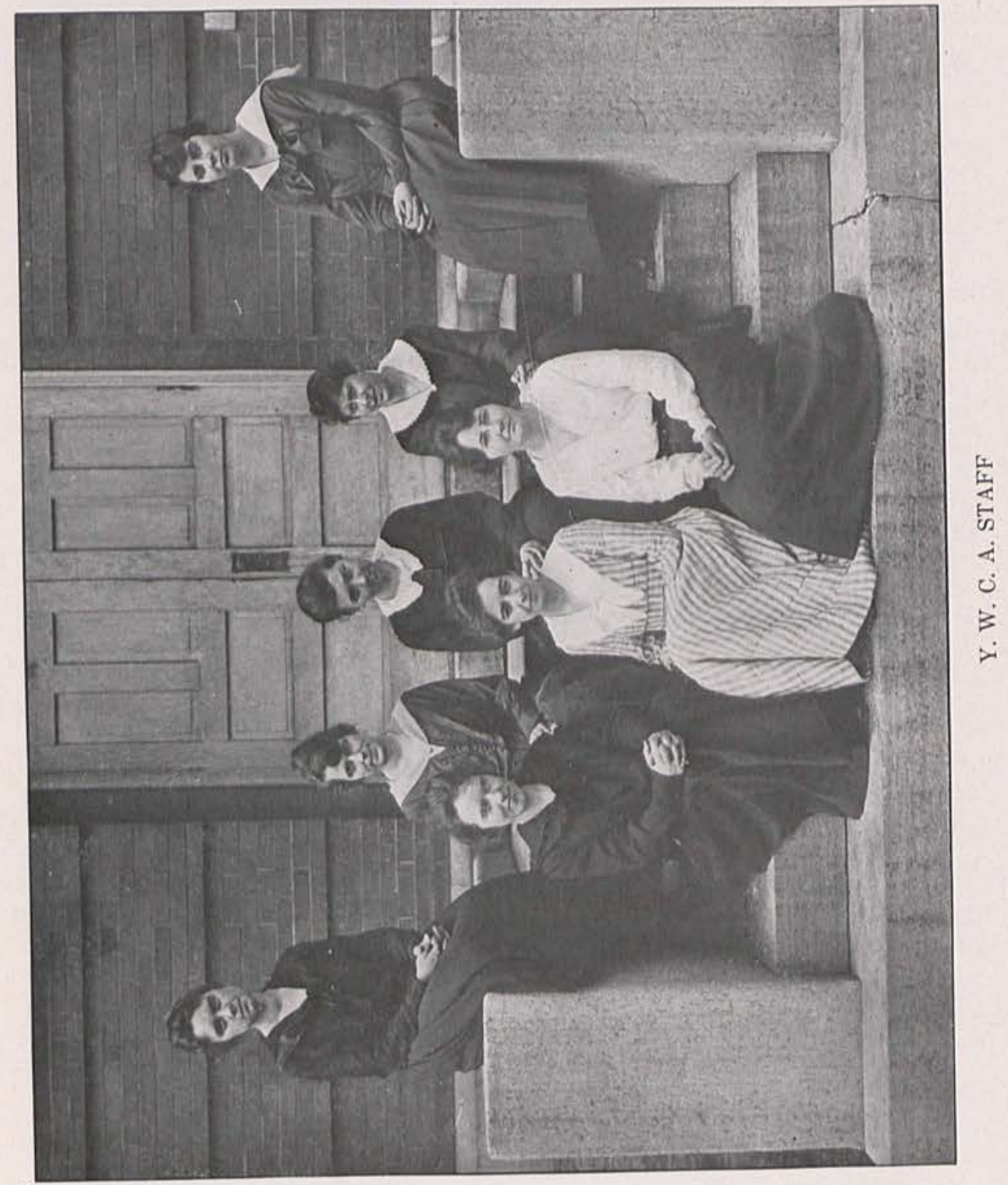



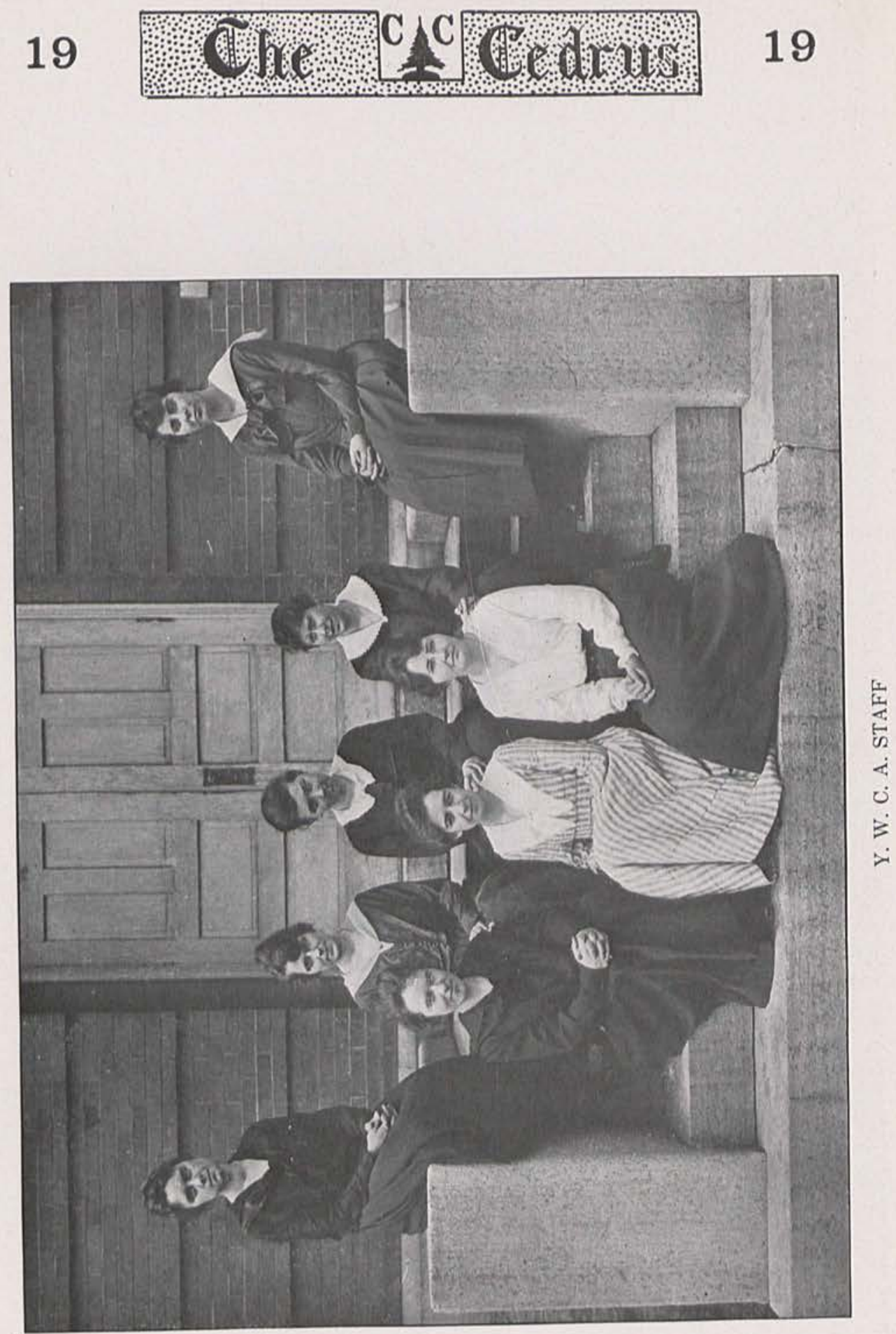


\section{9}

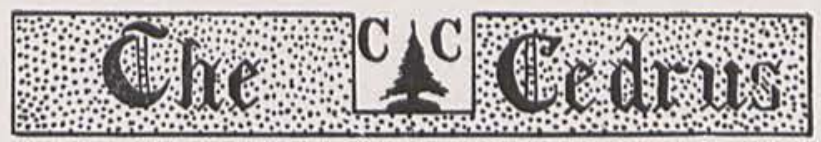

Y. W. C. A.

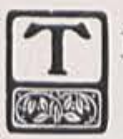

HE Y. W. C. A. has had an unusually successful year. Regular meetings have been held every Wednesday morning at the chapel hour, and these meetings have been well attended. Interest and enthusiasm have been kept up throughout the year, because all the girls have been loyal and faithful in attendance and in active work.

In February, the girls entcrtained the boys of the Y. M. C. A. with a valentine party in the gymnasium. A jolly, romping time was enjoyed by all, after which lunch was served.

We were exceedingly fortunate this year in receiving a visit from Miss Freda Klenk, a student secretary of the Ohio and West Virginia Division. She spent two days with us, conducting cabinet and group meetings, and these meetings were sources of real inspiration. Many valuable suggestions were given us, and some may have far-reaching results.

In April, the Y. W. C. A. presented a forty-dollar scholarship to the college. The girls then got busy preparing for the annual spring entertainment which was given in the Opera House, the latter part of May, and this program proved to be one of the best ever produced.

We are glad to be a part of this world organization, and we feel that it will go on through the years, ever prospering and gaining in influence and power. We are grateful that we, as the Cedarville College girls, can do our part, even though small, in helping such a wonderfully successful cause.

\section{Y. M. C. A.}

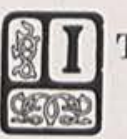

T IS evident in this Christian college that the Y. M. C. A. is an essential organization. As necessary as are the churches of this town to the community, just so necessary is this organization to the work of this Christian college. Although our present association does not measure up to the one hundred per cent efficiency standard, yet we in no way can realize what a help it is in keeping up the spiritual side of our school life.

Last fall our association greatly felt the death of the president, Paul Ellwood, and a shadow of grief has been hovering over the society which has not as yet been lifted. Meetings are held every Wednesday in which each member is given the opportunity to take some active part. The greatest lesson which we learn is that of standing up and speaking for the Master.

Every man coming to Cedarville finds himself immediately among Christian men whose sympathy, help, and encouragement are some of the assets of every new Christian student.

Officers: President, S. Morton Creswell; Vice-President, J. Edwin Bradfute; Secretary, D. Harold Hammond; Treasurer, Ralph L. Rife. 

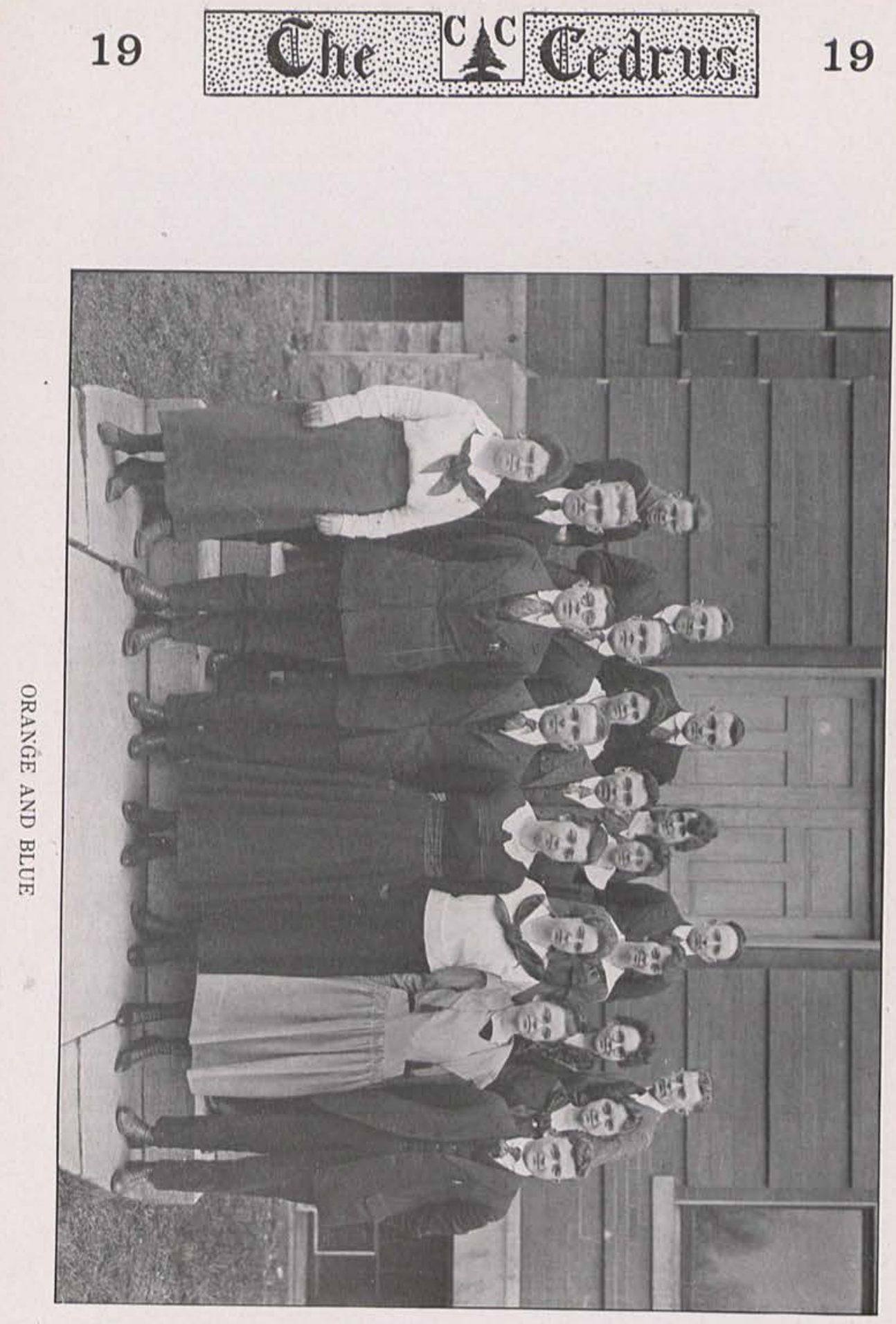


\section{A MID-WINTER NIGHTMARE}

Last night as I lay sleeping, I had a dream so queer,

It made me glad semester-ends come only twice a year.

I entered the college door, and went to the waiting room,

And there sat several of the girls filled with despair and gloom;

They said they'd been studying all night-and I don't doubt it a minute,

For compared with them, so pale and wan, a graveyard ghost wasn't in it.

I dropped exhausted into a chair-no farther could I go;

Then I listened to the questionings of voices sad and low.

"Oh, I know we'll have a test in Psych., I feel it in my bones;

And if we do, I know I'll flunk"-then followed a chorus of groans.

"Have you your Apologetics?" "Think we'll have a test in that?"

"You never can tell, but let's hope not-I don't know as much as a cat!"

"Ever have tests in Oratory? And if so, upon what part?"

"Well the class had one last year to repeat the entire book by heart."

Then a silence deep and solemn fell upon that group sedate-

Some were sighing, some were crying, all were thinking of their fate.

"Oh, girls! Do you know your History of Ed.?" "Is your notebook up to date?"

"Have you studied up on Rhetoric?"-"Chemistry?"-"Debate?"

"Are you looking for a test in French-in this, that, or the other?"

A pause - then a tearful voice sobbed out, "I'm going back home to mother!"

"Well, I-" But here a clang into the buzzing confusion broke,

And despairingly we started for classes-no one even spoke.

There stood Prof. Jurkat, eating an apple, within his class-room door,

So intent upon ringing the bell on time that he even swallowed the core.

We slowly and sadly crept up the stairs to the second-story hall,

And then we scattered here and there to our class-rooms, one and all.

Some of us started for Economics - twas the hour for it to recite,

But the sight that greeted us at the door made us almost faint wih fright.

That board was covered with questions (oh, how we wanted to run!),

And there stood Prof. Allen handing out whole tablets to every one!

"Now, don't be alarmed," he smilingly said, as he twirled his watch-chain around.

"If you've mastered each lesson day by day, for fear there is no ground;

This test is not a hard one - eight hours I think should be

Sufficient to answer every question that on the board you see."

At last I ventured a timid glance, then my heart began to hop,

My eyes swam about in lakes of tears and my brain reeled 'round like a top.

"Write an outline of the entire book - each chapter and sub-division."

"Wo you think more silver or gold should be used? Give reasons for your decision."

"If prices rise in Europe, does the rise effect everything?",

"And please explain by natural laws how a price can 'fall' in the spring."

"And please explain a complete and accurate map of the world and locate all trade centers."

"Who profits more by prosperity - the landlords or the renters?"

"When is legal tender, and when is it harsh and severe?"

"Tell how to counterfeit a dollar-diagram to make it clear."

"Name the greatest financier in the business world today;

"Nraw his picture, tell his history; is his hair red, black, or gray?"

"What is a clearing-house, and is it built of brick or wood?"

"Draw a picture of the very first bank, and tell just where it stood."

"Name all-" Then came a noise like the sound of a great earthquake!

"Twas the alarm-clock bell and for once in my life I can say I was glad to awake.

Then as my thoughts became clearer and I stroked my fevered brow,

"How glad I am," said I to myself, "that I'm a Senior now!

Test worries will soon be over and smiles will replace our tears;

But something should be done to help the students of future years!

Slavery now has vanished from our good old U. S. A.;

Booze has followed in its step - both have had their day;

All things vetoed by the majority must follow along with the rest,

So may the next Amendment abolish the College Test!" 


\section{9}

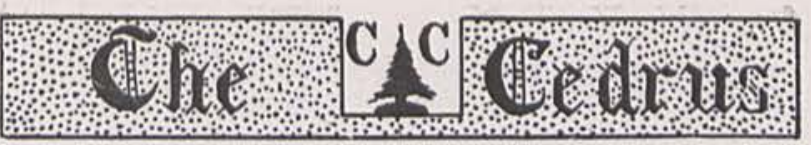

19

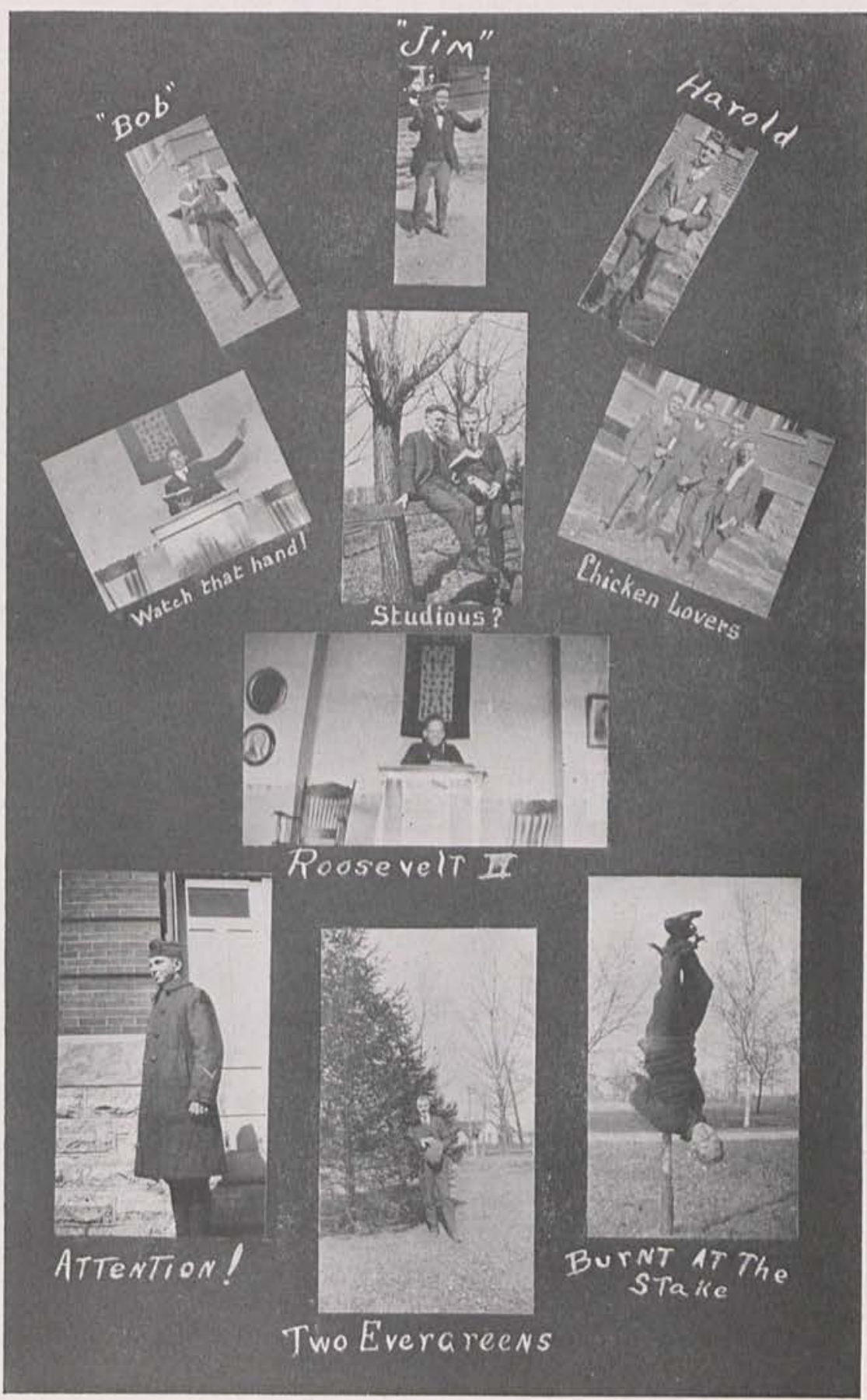




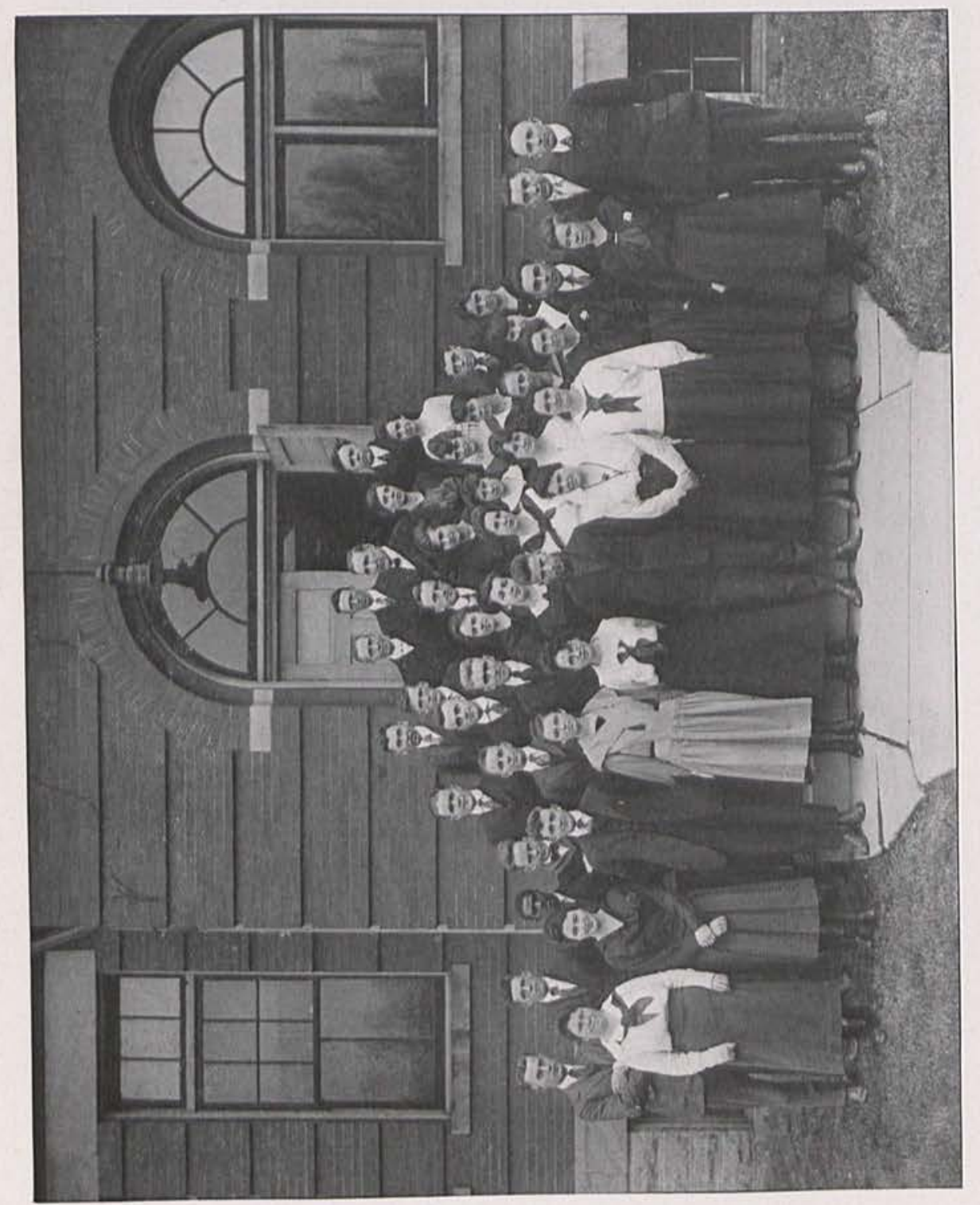

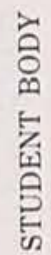


19

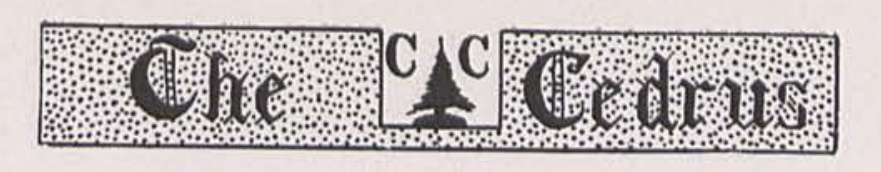

19

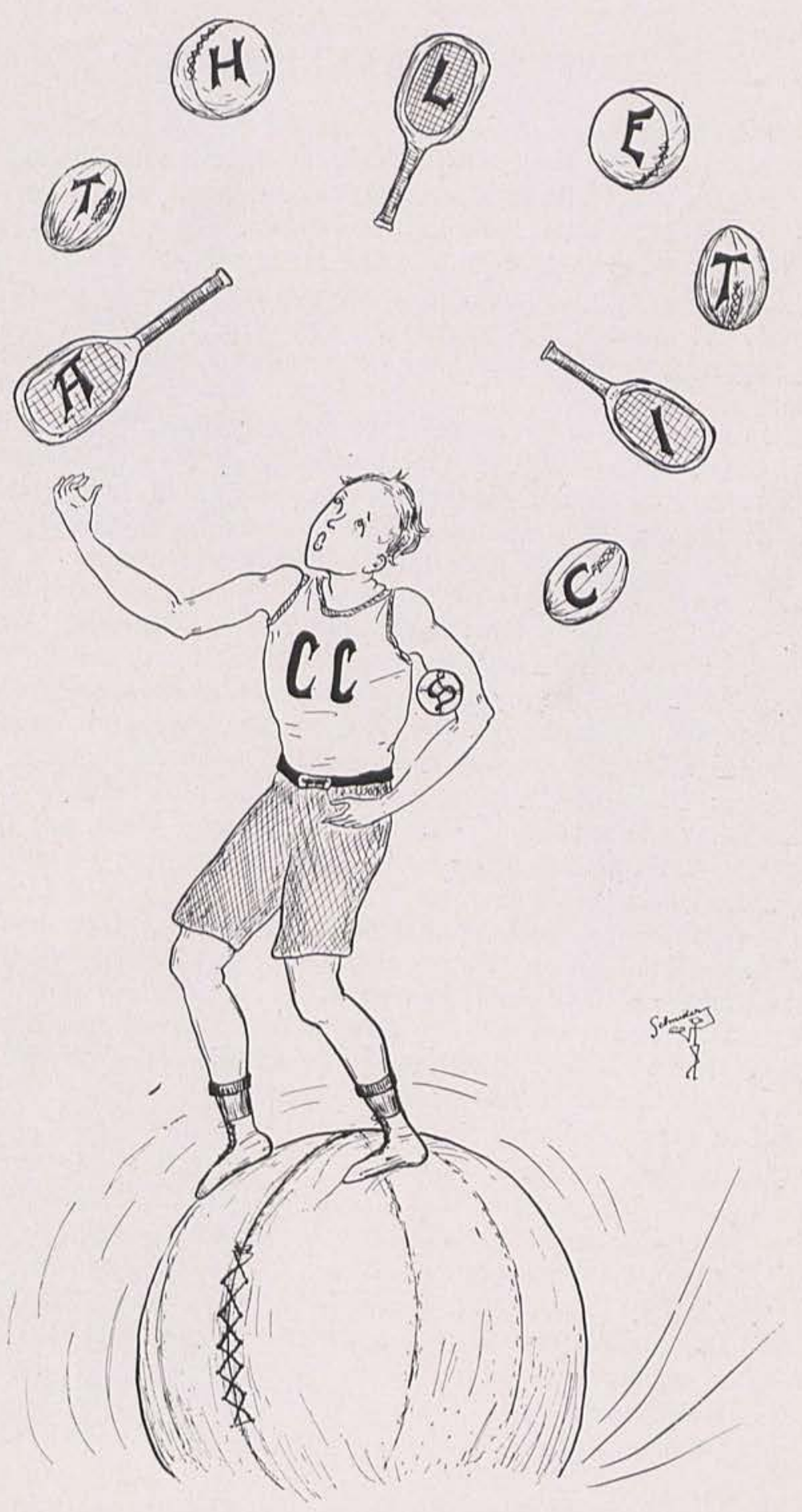




\section{BASKET BALL 1918-19}

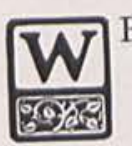

E HAVE indeed closed a very successful year is basketball. Early in the fall, Mr. Roger Collins was chosen manager and J. L. Chesnut captain. The boys were soon called out to practice and given to understand that each man was to have a fair trial for the first team. The following men were selected for the team: William Bussey, center; R. Collins, left forward; M. Creswell, right forward; W. Collins, right guard; J. Chesnut, left guard; the two other men selected were $H$. Wright, forward; E. Huey, and later in the year N. Thorne was added to the team.

We are very proud of our record; we did not lose a game on our own floor and only lost three abroad. We won seven games and lost three. We opened the season at Wilmington, which was probably the best game Cedarville put up all season. Chesnut opened the scoring by throwing a field goal from the side line, and after that the whole team seemed to have the spirit of "Now let's go," and we surely did. The game ended 53-27. It was the largest score that Wilmington ever lost to Cedarville. The other game that attracted special attention was the Muskingum game. The boys gave Muskingum a great run, only to be nosed out at the finish. However, we left Muskingum with the record of playing the fastest and cleanest game played on their floor in the last two years. The leading man in scoring was Manager R. Collins, and he had a good running-mate in Creswell. William Bussey was always on hand with some fancy plays, and the other boys were usually found doing their part in breaking up passes and making a few goals.

With the material on hand for next year, Cedarville College should again make a creditable showing. We are sure Cedarville College will always be a good booster for athletics and her men will go out stronger physically and mentally. Time and space will not allow us to go into detail on the games and players, but we believe by our record we have had good team work and every man had a chance to play in several games.

The games were as follows:

$\begin{array}{lcc}\text { Cedarville won from } & \text { Lost to } \\ \text { Xcnia } & \text { (Forfeited) } & 0 \\ \text { Wilmington } & 2 & 1 \\ \text { Miami Conservancy } & 2 & 0 \\ \text { Sabina } & 1 & 0 \\ \text { Dayton Miamis } & 0 & 1 \\ \text { Otterbein } & 0 & 1 \\ \text { Muskingum } & 1 & 0\end{array}$




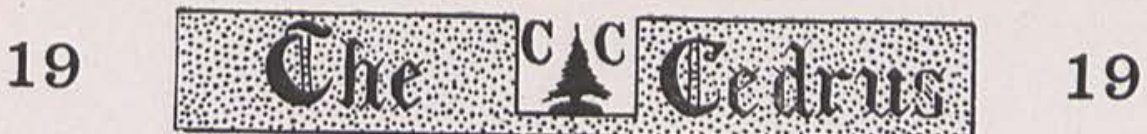

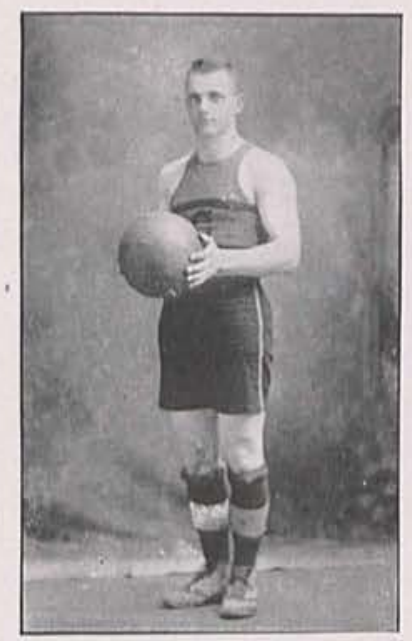

R. Collins (Mgr.), Left Forward "Roge"

"Say, fellows, we got to take these

M. Creswell, Right Forward "Cressie"

"What a lucky shot!"
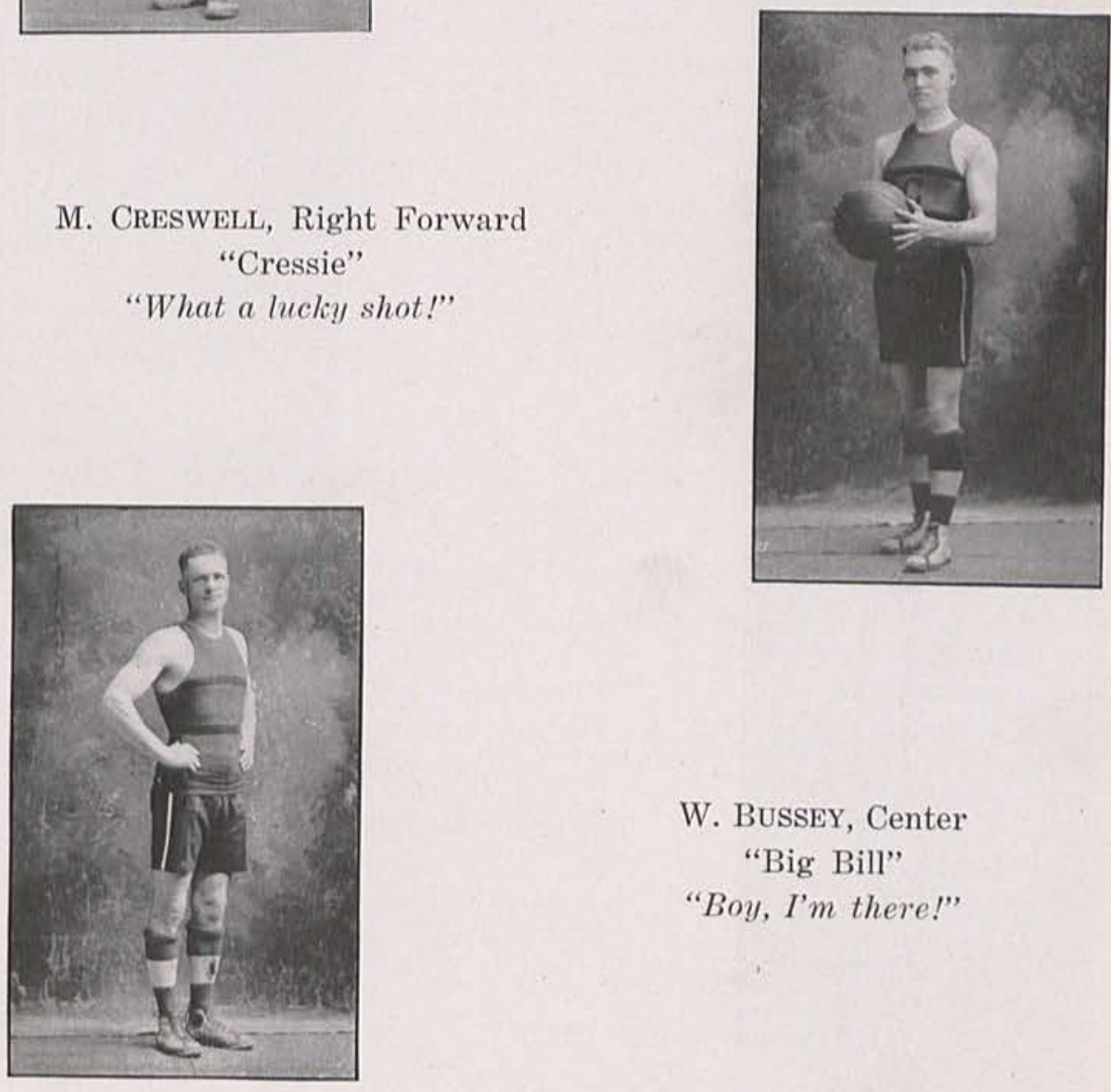

W. Bussey, Center

"Big Bill"

"Boy, I'm there!" 


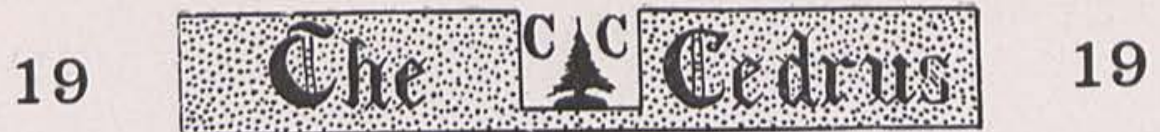

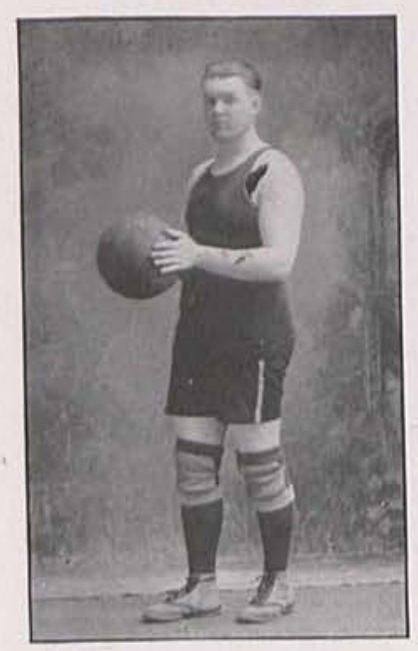

W. Collins, Right Guard "Bill"

"Come on, let's get into this."

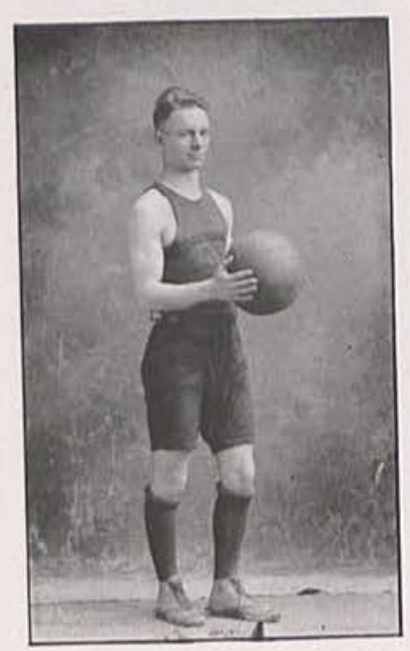

J. Chesnut (Capt.), Left Guard "The Irishman"

"Now, let's go."

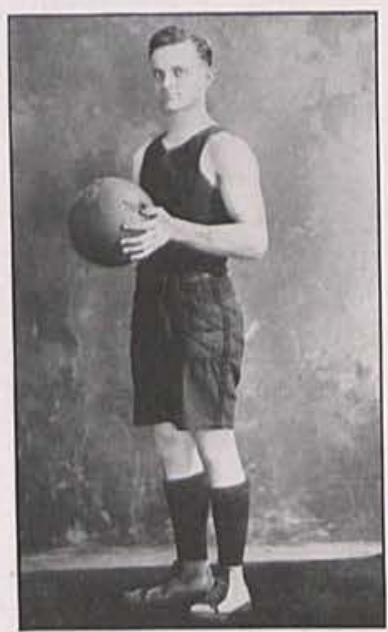

N. THORN, Utility Guard "Nell"

"Who's that pretty Jane?" 

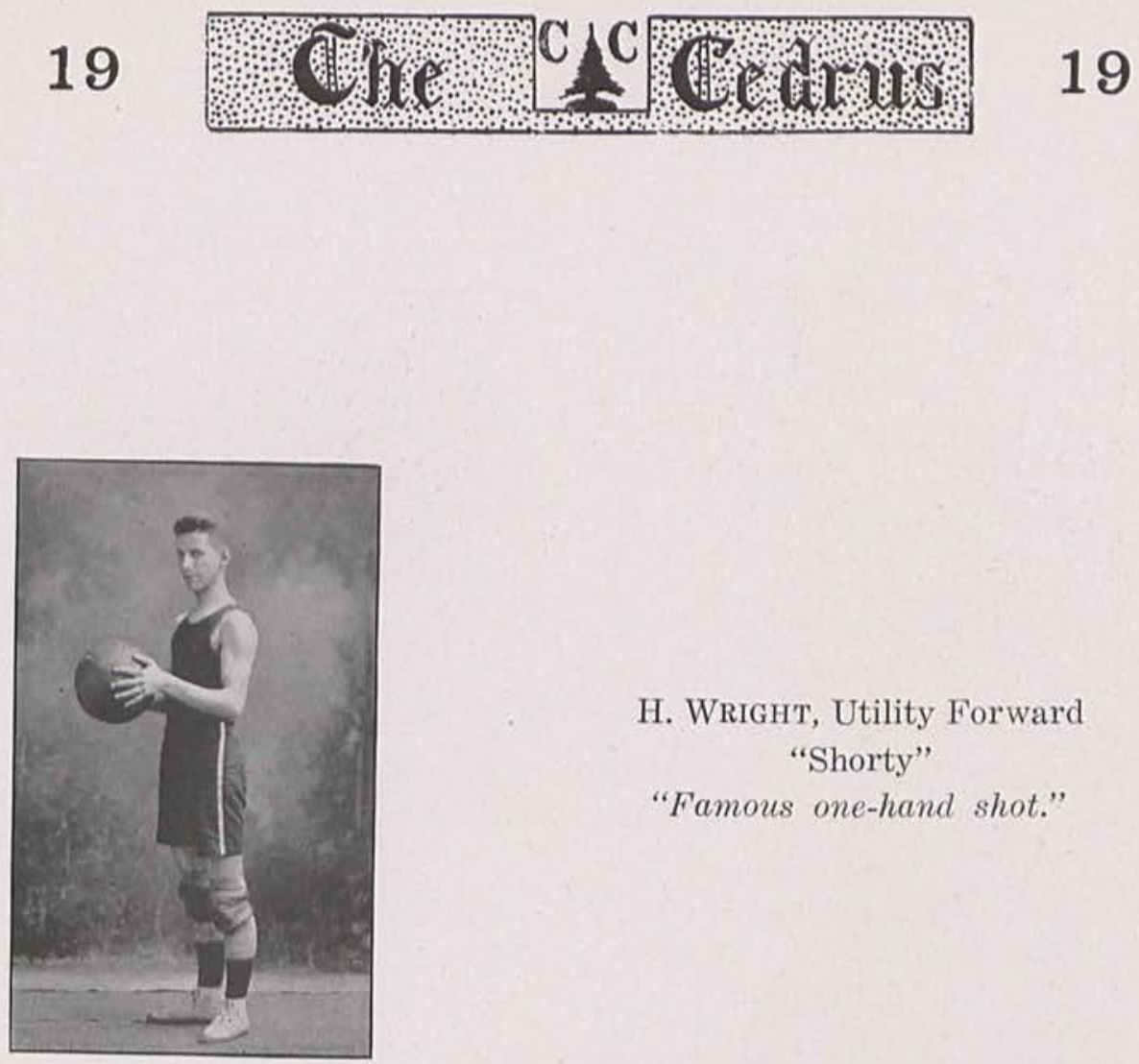

\author{
H. WRIGHT, Utility Forward \\ "Shorty" \\ "Famous one-hand shot."
}

E. HuEY, Utility Guard

"Illinois"

"A good steady guard"

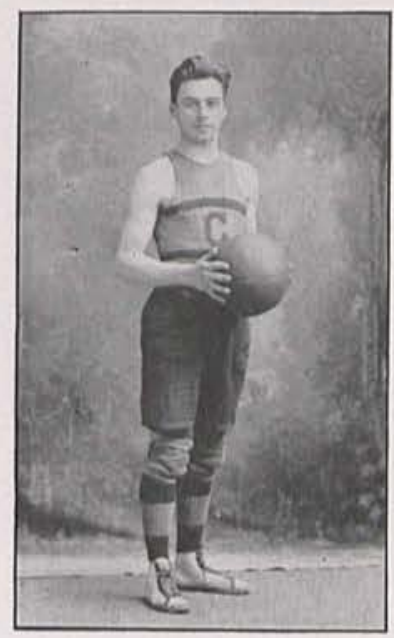




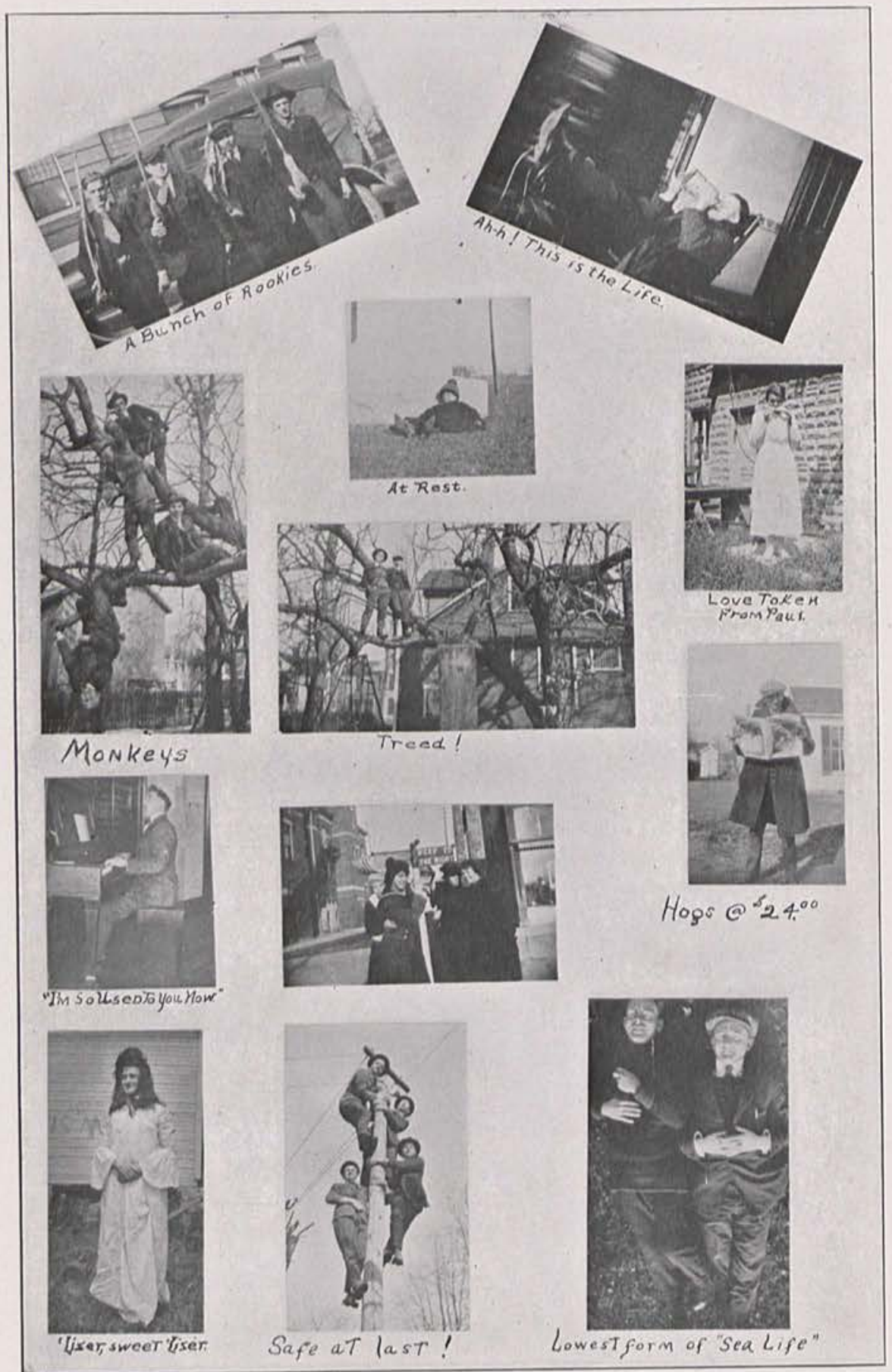



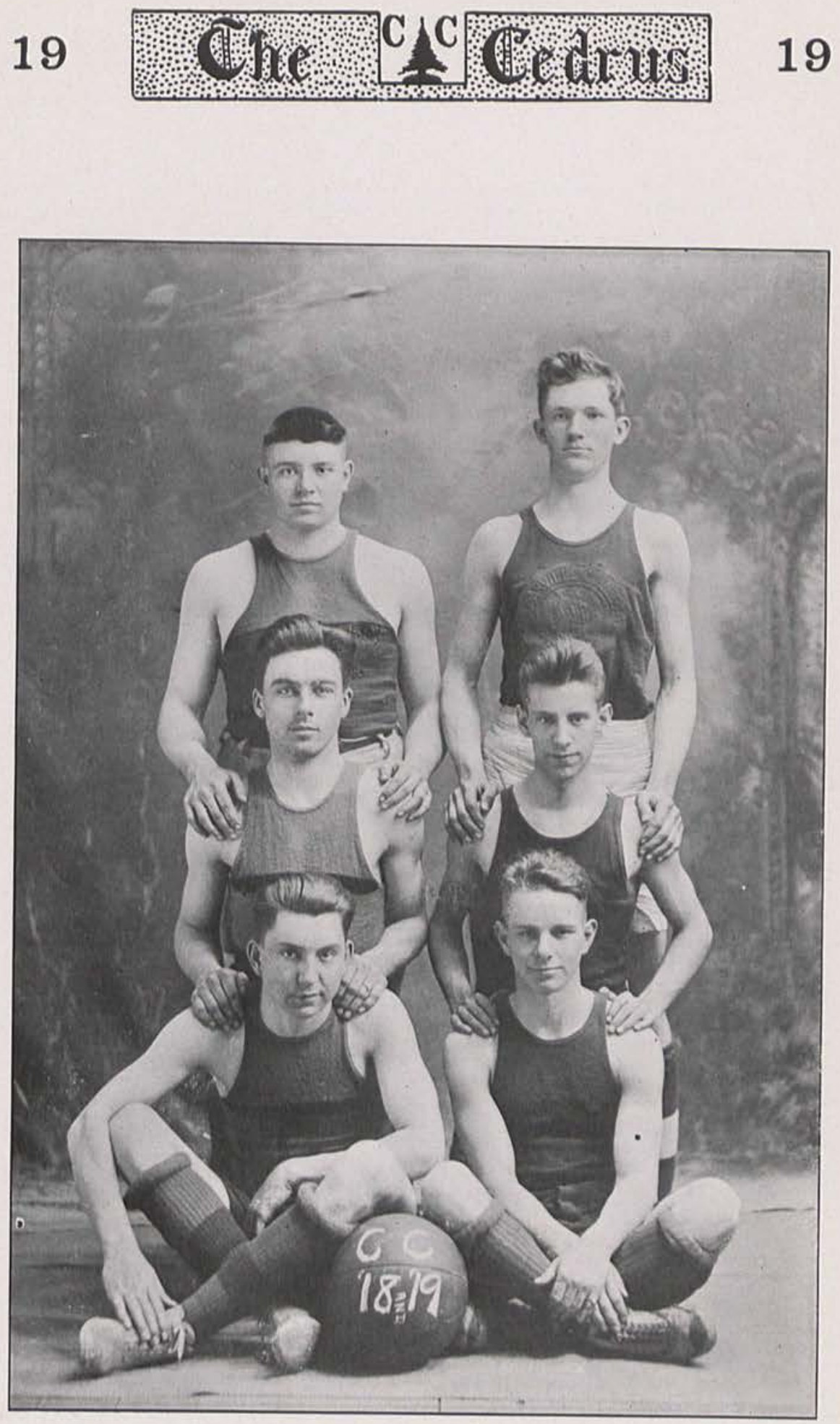

SECOND TEAM 


\section{BASE BALL 1918}

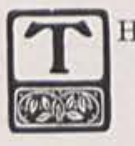

HE baseball season of 1918 at Cedarville College, although short, was very satisfactory and was an unqualified success. But whoever heard of a team with a chicken-swipin' preacher for a captain, that didn't make good? Add to this the fact that the other eight members of the team never were able to look a chicken squarely in the face in broad daylight, and you will see why the 1918 baseball team of Cedarville College occupied such a prominent place in the sun all through the season.

The season began rather inauspiciously, to say the least. Rainy weather kept the diamond in a muddy condition till the first of May. About this time came the first scheduled game of the season, with Antioch at Yellow Springs, so we were forced to cross bats with the Fess-ites without a single real practice on the diamond. However. the odds were about even, for Yellow Springs had been visited by a like amount cbi? rain, so the Antiochians were as much in need of practice as we. The game was rain, so the Antioch both teams swatting the "pill" with considerable regularity. An. tioch proved to be the most successful, though, at making their hits produce runs, for at the end of the game C. C. found herself on the short end of an 8 to 11 score.

The mud dried up about this time, however, so Captain "Jim" got his proteges out regularly every afternoon and some good practice was gotten, putting us in better condition for the next game, with our Quaker brethren and rivals from Wilmington Coldition the game was played on the Wilmington diamond, and it turned out to be an lege. The game was played on the Wame it became evident that the contest had resolved ideal baseball day. Early in the game it became evident that the contest had resoled and itself into a pitcher's likewise elongated (laterally) pill-tosser. The fifth inning Chesnut, "Cedarville's likewise elongated "lucky proved a "Joner" for Cedarville, and the enemy annexed two runs. It took "little show" seventh," however, for Cedarville to put on her "little show." When said "little show" was over, we were on the long end of a 3 to 2 score, largely through the timely hit of Duncan, who was sent in as a pinch hitter. The last two innings were scoreless, so

Cedarville departed for hom
right end of a 3 to 2 score.

The third game was with Cedarville High School, but we had but little trouble in disposing of them by a score of 6 to 1 .

The next game was our return game with Antioch. This was on Cedar Day; so in addition to getting revenge on our ancient rivals, we couldn't very gracefully lose our Cedar Day game. After a week of intensive practice, we felt ready to take on Antioch or anything else in the way of a baseball team. So, shortly after the game began, we got busy with our war clubs, and when the dust of Antioch's home-going warriors had got busy with our war clubs, realization of the fact that we had taken their measure to cleared away, we came to the realization of the fact that we hatioch for the year, as each team had also won a game in basketball.

With three victories out of four games to our credit, we got ready to make it four out five with Wilmington in the final game of the season. Like the game at Wilmington, this contest was also a pitchers' battle. Three bunched hits late in the game including a home run by Harry Wright, netted Cedarville two runs and enough to win the game by a 2 to 1 score.

Thus the a victories and one defeat. The success of the team was due largely to two important factors-factors that contribute to the success of any baseball team; viz., good snapnv teamwork. and the ability to hit th ball where a hit meant a run. The line-up and batting order for the season flollows:

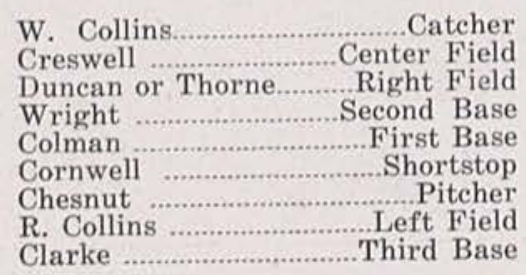



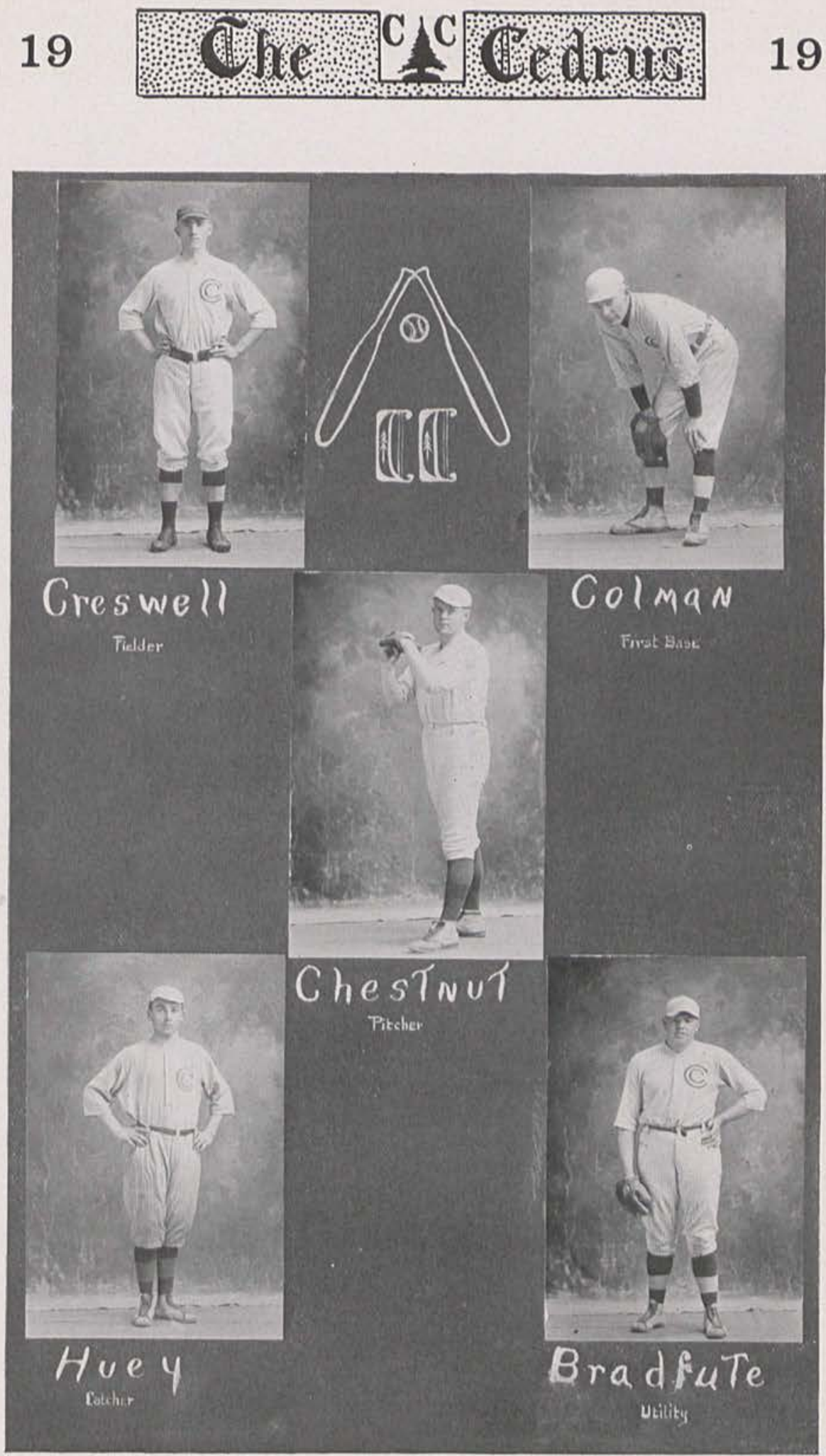


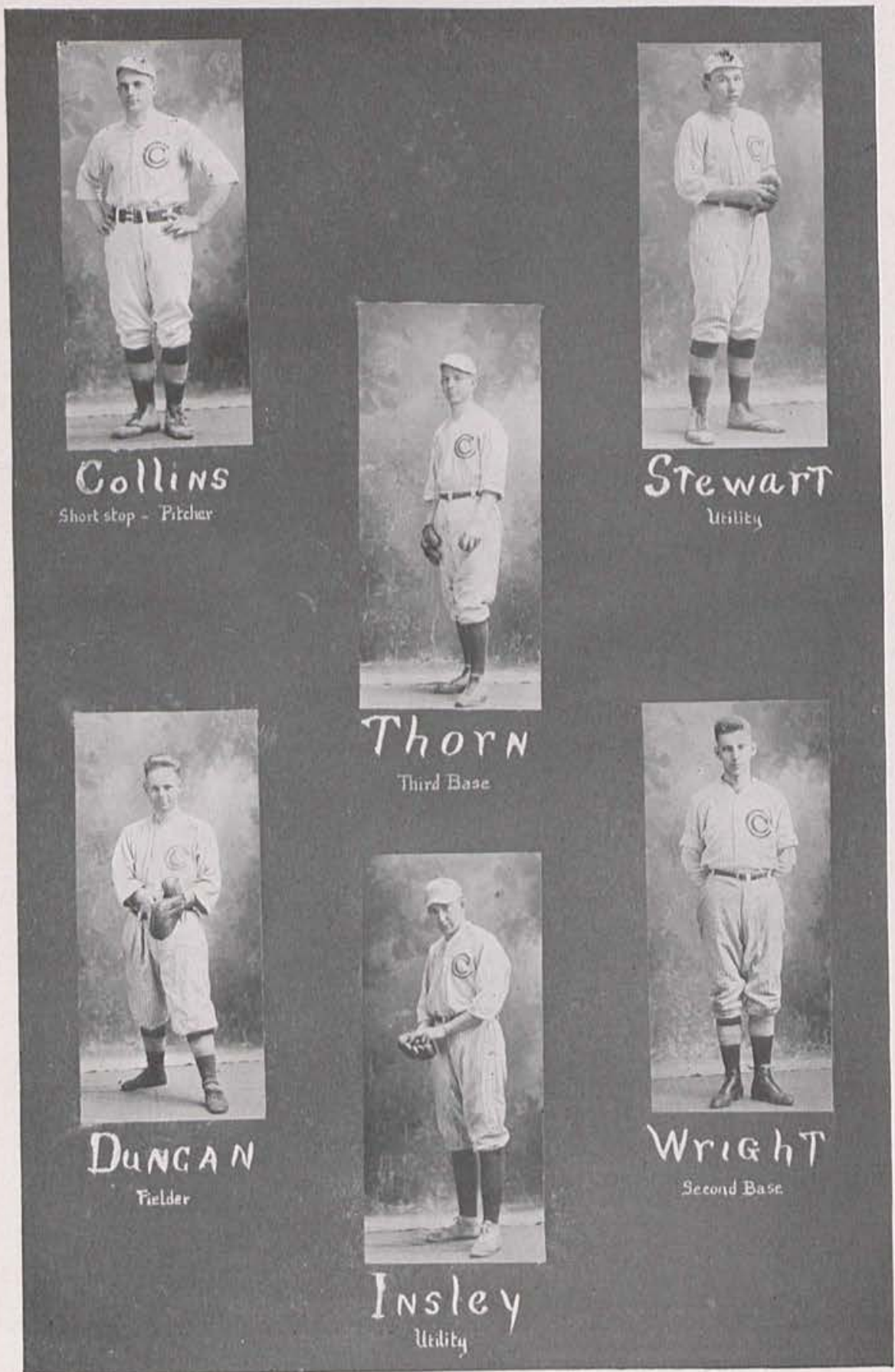




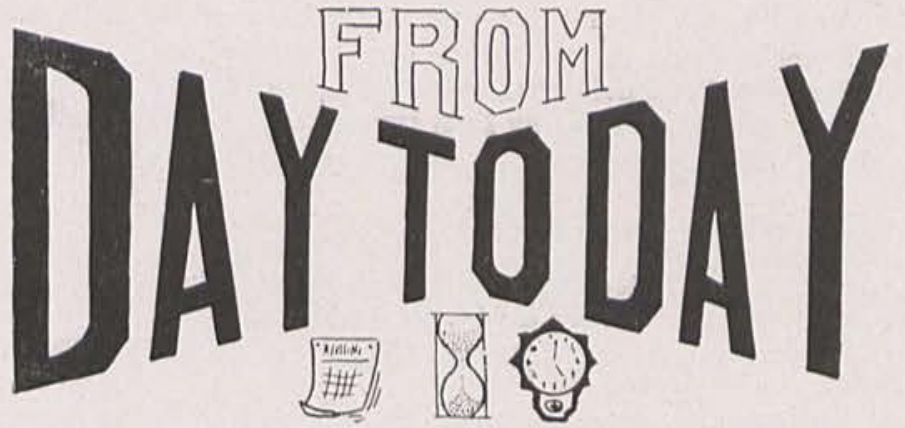

SEPtember 9. The $6: 47$ bears into town with great care, as does also the $6: 20$, for the students are coming back.

Septemrer 10. Schedules made out. Greet new students, also new professors.

SePtemeEr 11. Splendid opening address by Rev. Tapey. Lessons assigned. Old friends meet again.

SEPTEMBer 12. Registration Day. Great interest in getting acquainted with methods of the new professors.

September 13. Students and faculty wend their way to the R. P. Church where the social of welcome is given.

SEPTEmber 16. Prof. Allen tells economic class he hoped they will become wiser and more beautiful.

SEPTEMBER 17. Seats assigned in chapel. Some dissatisfied, but abide by the powers that be.

SEPTEMBER 18. Lab. students informed that they must work.

SePtember 19. Under classmen feel the iron rule of the Senior teachers.

September 20. Two weeks of rain. Now we can hope for pleasant weather.

SEPTEMPER 23. Prof. and Mrs. Wesley give Club members a view of "married geniality." Prof. positively refuses to wear his hat as Mrs. Wesley wishes him to wear it.

SEPTEMBER 24. "Oh, dat watermelon spread and broken window!" All enjoyed a good time.

SEPTEMBER 25. Just rain.

SEPTEMBen 26. Funeral of Rev. Ernest Foster, '13, attended by Faculty and Seniors. SEPTEMrer 27. The pleasure of hearing Dr. John R. Mott was afforded all students. Some misfortunes encountered-

"Battery in one machine burned out,"

"Gasoline ran low in another,"

"A third lost its way."

The last stragglers arrived at ? a.m.

SEPTEMBER 30. Miss Rea asks for "The Law of Boils" in Chemistry class.

ОстовеR 2. Economical principle, "Save everything you can; make tooth-brushes from hog bristles," OCTOBER 3. Rickenbach makes his one known gesture, "holding hands," in Extempore
class.

OCTOBER 4. Have a visitor in our town, very prominent and visits many.-Flu.

OCтовеR 6. Paul Elwood and Bob Colman have the flu.

OCTовеR 11. Having lingered for a week and with no chance of beginning school, many students go home.

OCTOBER 18. Death called our jolliest-Paul Elwood.

NOVEMBER 18. College opened with its usual greeting, rain.

November 19. Short stories read. Some members of the class will no doubt soon publish their productions in magazines (??). 


\section{9}

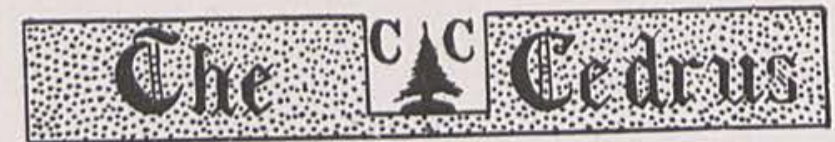

NOVEmBer 20. "The best thing to do when it is raining is just to let it rain." That is what we did.

NOVEmber 21. An enjoyable evening for some at the home of Helen Creswell.

NOVEMBER 29. Thanksgiving. A real turkey dinner en joyed.

NOVEMBER 30. Thankful to be living yet, after the meals enjoyed yesterday.

DECEMBER 1. Exciting baseball game by Paul Duncan in the Orange and Blue meeting.

DeCEmber 4. Prof. Allen never receives any candy from the girls since he was married.

DeCemeer 5. Girls buy best box of candy in town and send it to Prof. Allen. Will see results Monday. Lecture by John Kendrick Bangs.

DeCEMBer 9. Prof. Allen ate too much candy and is not able to be at scheol.

Decemper 10. Prof. Wesley receives cards to help him entertain the flu.

DECEMTER 12. Cloaks mysteriously disappear from the girls' waiting-room. Are found after several walks around the building.

DECEMBER 13. Freda not having caught the flu from Ruth Ramsey, thought she might have "the next fellow that comes to town. I'll kiss through a handkerchief." Bill was next.

DECEMBER 16 . Entertained at Orange and Blue by address by William Rife Collins, returned from the army.

DeCEMBER 17. Freda says, "Every girl strives for the universal heart of man."

DECEMBER 18. Ellen, I don't like that. "Linger always goes with summer for me."

DECEMBER 19. Cedrus staff elected. Tie for assistant editor, not to be broken until 1919.

DECEMBER 20. Christmas program rendered in chapel.

JANUARY 1, 1919. New Year's Day. Begun a-right by reciting all classes.

JANUARY 2. Morton Creswell says that money lasts longer in the country than in town. There's a reason. . . .

JANUARY 3. Debate: Resolved. That one hour's work per week makes one eligible for athletics. Affirmative, The Boys; negative, The Faculty.

JANUARY 6. Interesting talk by Bird and Brubaker, both khaki-clad boys.

JANUARY 7. Lieutenant P. H. Creswell addresses student body. He's been "over there."

JANUARY 8. Miss Marsh shows her knowledge of farm life. "Straw is baled hay."

JANUARY 9. "One little bit of talking done,

One little cross word spoken,

Has power to bring two Seniors down

Even from the perch they've taken."

JANUARY 10. Tribute paid to Roosevelt by different members of the Faculty and students. Basketball, C. C. versus Wilmington, 59-27.

JANUARY 13. Practice songs and cheers. Orange and Blue meet.

JANUARY 15. Edwin Bradfute singing, looked at Louise, "None like thee."

JANUARY 16. Freshmen love the college so, they spend some time at night on the campus.

JAITUARY 17. Wilmington versus C. C. Score 36-31 C. C. Oyster feed after game.

JANUARY 20. Freshmen see results of spreads when they see their Chemistry grades.

JANUARY 21. Hammond suggests halfsoles be made from beef had for supper at the club.

JANUARY 22. Club number grows. Bob Edwards.

JANUARY 23. Attractiveness of club becomes known ar.d Huey joins the ranks.

JANUARY 24. C. C. verses Dayton Engineers. 54-29 score.

JANUARY 27. Sulphur has many properties which are not harmful, but care should be taken when it becomes hot, for it gets "viscious."

JANUARY 28. Lecture Course. Splendid Scotch program. Two girls fail to get the longed-for candy.

JANUARY 29. Bradfute, when Jamestown was mentioned: "What'd you say about me?"

JANUARY 30 . Rule for giving piece in oratory as suggested by Turnbull: Begin in the middle and go both ways.

JANUARY 31. Dr. MeChesney entertains Faculty and students. Delightful evening for all. Three cheers for our president. 


\section{9}

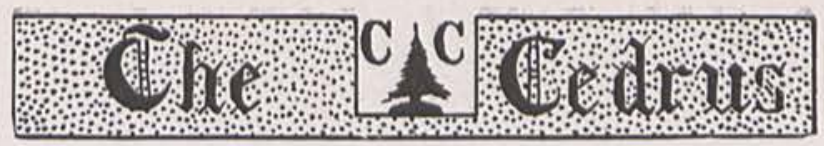

February 3. Very interesting meeting of the Orange and Blue. "Hungry March" by the Club is played by Bob Colman, and Prof. Allen gives an interesting lecture which occupies three-quarters of an hour.

February 4. Oratory class learns to laugh. Other Prof. wish they never had.

February 5. Observation class goes to Dayton. C. C. versus Springfield Triangles, $45-28$.

February 6. Hammond pitches his tents toward Tyre and Sidon.

February 7. Memorial services for those who have finished their work on earth.

February 11. Sermon in Chapel by Paul Duncan.

February 12. The children of the college attend Community Club banquet. Paul and Ida.

February 13. Duncan criticizes Ida in Extempore. "It's the best speech she's made."

February 14. Day of prayer for colleges; also end of the semester.

February 17. Beginning of second semester. Every one so rested after the semester vacation. Lecture by Rev. McKibben.

February 18. Cornwell, '19, in service for his country, gives interesting talk to students.

February 24. McChesney says, "Any preacher can make chickens pay over night."

February 25. Miss Greer enjoys "good country butter" so much she eats extra slice of bread.

February 26. Boys have feed in the Gym. Somp girls try to enjoy it too.

February 28. Prof. Allen says, "Marrying off our boys is a very interesting and helpful discussion."

MARCH 3. Ellen Tarbox becomes top-heavy and falls off her chair in history class.

MARCH 4. Chemistry class measures gas by bushels and quarts.

MARch 5. Bob Colman and Louisa Greer hold hands at supper time at the Club.

MARcH 7. Miss Marsh loses her dignity over her feet, in Extempore.

MARch 12. Splendid lecture by Russell Conwell. "Acres of Diamonds,"

MARch 17. Prof. Allen tells how hired girls and custard pies may be brought together. Courting.

MARch 19. Cedar Orator and Spirit of Cedarville chosen.

MARCH 20. Ellen T. classifies all farmers on a basis of her knowledge of one family.

MARCH 25. It sure was "Blue Monday." Miss Rea couldn't spell nor write.

MARCH 27. Practice songs in Chapel.

MARCH 28. Prof. Allen "drops the second shoe" and about fifteen students help him pick it up.

March 31. Dr. Hammond, of Cincinnati, addressed Orange and Blue Club. Soph's have spread.

APRIL 1. Excellent services conducted by Dr. J. Alvin Orr, Pittsburgh, Pa. In the p.m., the boys tried to see if their auto horns would work well. Algebra reciting. Being All Fools' Day, the girls fooled the boys into believing there was a spread. For their "foolishness," about six boys had to settle with W. J. Tarbox for some glass.

APRIL 2. Under classmen feel that the Seniors are indeed their superiors. They were able to go "over the top" of some of them very easily.

APRL 3. Peace and quietness reign supreme.

APrIL 7. Miss Schneder lines up the years of the college. Paul Duncan is the youngest.

APRI 8. College entertained at home of Gordon Collins. Everybody enjoyed themselves.

APRIL 12-19. Three members of CEDRUs staff have the flu. Delightful visitor.

APRIL 25. CEDRUS goes to press under direction of assistant editor. Main boss still has the flu. 


\section{THE EARLY YEARS}

HE writer arrived in Cedarville on the morning accommodation, July 10, 1894. A mass meeting to put Cedarville College for the first time before the people was held that evening in the opera house. The speakers were James F. Morton, David McKinney, James D. Steele, Thomas Watters, and the writer.

Canvassing for students began the next day. Thirty-seven enrolled on September 19, 1894. Thirty-three of them were in the collegiate courses, four in music. The first faculty were David McKinney, president; James F. Morton, vice-president and professor of English Bible; W. R. McChesney, secretary, and professor of Ancient Languages; Carrie Blair, professor of Mathematics; Frank Dean, professor of English; and Bell Beazell, professor of Music.

The college occupied during the first year the residence of Dr. Hugh McMillan, which is now owned by Mr. Arnold. Ground was broken for the present building on the campus in the spring of 1895 . The new building was entered the following September. Some sixty students were in attendance.

The endowment of the first three years was only $\$ 20,000$. This has been increased until at the present it amounts to $\$ 105,000$ actual interest-bearing endowment. Some $\$ 30,000$ additional endowment is expected in the near future. The Theological Seminary endowment amounts to $\$ 68,000$. It is combined with the former, and the College has the benefit of both funds amounting to $\$ 173,000$. A movement is on foot now to raise $\$ 25,000$ for the James Foyl Morton Bible Chair. Quite a good sum has been raised already.

The charter Board of Trustees were James F. Morton, Thomas Gibson, Richard Park, Hugh McCollum, Jr., and H. H. McMillan. In the opening year of the College, David McKinney, Thomas Watters, Robert Stevenson, James D. Steele, and J. C. Stormont were added to this Board.

The early years were filled with effort, struggle, and sacrifice. However, hope kept the fires of enthusiasm burning brightly and led on and up until the splendid plant of the present flourishes as the achievement of those days of mixed fear and faith. The past with its labors and joys, the present with its attainments and prospects, bids us enter the future with gratitude to God, reliance upon our hosts of friends, and every encouragement to make the coming years the best. 


\section{THE TWENTY-FIFTH ANNIVERSARY}

OMMENCEMENT, 1919, rounds out a quarter of a century of service for Cedarville College. Twenty-five years of achievement! Scores of young men and women sent forth with college degrees to lead the world to higher and better things! Hundreds more rigerse educated within her walls! A whole community edified and elevated by the
uplifting presence of the institution. This is the record, and of it the Col-
lege and all interested in it are justly proud. It lege and all interested in it are justly proud. It is fitting that the whole of commencement week should be devoted to the celebration of this event.

But Cedarville College is not relying upon its past attainments. The twenty-five years that are past are but stepping-stones to better things. The chief significance of the Quarter-Centennial is not that it marks the close of the first period of Cedarville's history, but that it signalizes the opening of the second period. Cedarville College has its face to the future.

Under the presidency of Dr. McKinney, the College was well and firmly established. But all through the twenty-five years that are past, one name has been associated with the College, and that is still a name to conjure with-it is the name destined to be associated even more potently with the second period of twenty-five years than with the first- the name of Wilber Renwick McChesney. His presidency, we all believe, is to mark the expansive movement that shall make the College what it ought to be and give it the place in the educational world that it ought to have. Though he has seen twenty-five years of service in the College, he is still a young man, in the prime of his manhood and power, and in spirit is the youngest and most hopeful of all engaged in the work. He has great plans for the future, plans that are practical and plans that, when carried out, will make Cedarville College a great institution. By the help of God and of all the friends of the College, these plans will be brought to fruition in the near future, and will make the second quarter century far more glorious than the first.

\section{THE SCHOLARSHIP CAMPAIGN}

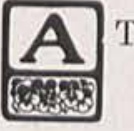

THE beginning of the year 1918-1919, Cedarville College faced the same situation that confronted practically every college in the country. War prices had either already caused serious deficits or were threatening them. Cedarville College had never had a financial deficit in its history. But one looked inevitable now. But Dr. McChesney rose to the crisis. He called for forty scholarships to meet the immediate financial need and at the same time to provide instruction for worthy young men and women who would otherwise be denied the privileges of a college education. The friends of the institution also rose to the emergency and contributed within a few months forty-three scholarships. The College was saved the embarrassment of a deficit and abundant provision was made for the education of future leaders in church and state.

War prices still prevail. The expense of the College for the coming year will necessarily be greater than $\in$ ver. To meet this added demand, President McChesney has called for twenty-five additional scholarships of forty dollars each. These will pay the tuition of worthy young people and at the same time will help the college to meet its bills. 


\section{THE JAMES F. MORTON BIBLE CHAIR}

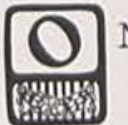

NE of the biggest movements started by President McChesney is the campaign to raise an endowment fund to provide permanently for the teaching of the Bible in the College. The Bible always has been taught in the College, but in the past the instruction has been given by professors holding other chairs. The establishment of a chair in Bible would permit the employment of a separate professor of English Bible. Friends have suggested that the chair be named after the Rev. Jams F. Morton, D.D., for forty years pastor of the Main Street Reformed Presbyterian Church of Cedarville, the first vice-president of the College, the first professor of English Bible, and long a member of the Board of Trustees.

It is proposed, in honor of the twenty-fifth anniversary of the founding of the College, to raise twenty-five thousand dollars - a thousand for each year of its history-for the establishment of this fund. Already three thousand dollars in actual cash has been contributed, and the campaign has hardly begun. All who revere the memory of Dr. Morton, all who are interested in the teaching of the Bible, all who desire the advancement of the mental, moral, and spiritual uplift of Cedarville College and community, and for the establishment of the kingdom of God, are asked to contribute to this fund.

\section{FIFTY FRESHMEN FOR NEXT YEAR}

CAY, do you suppose it ever will come true?" "What?" "Why, Dr. 6 MY, do you suppose it ever will freshmen for next fall. Wouldn't it whole shebang." "But can they pull it off?" "Well, honestly, I believe they're actually going to make good. Why, say, Dr. McChesney and all the profs are chasing all over the state after high-school graduates who never even heard that there was such a thing as a college; they go and make life miserable for him until he promises to come to Cedarville." "Well, believe me, that's the spirit!" "And the students are all writing letters and trying to get their old pals to come, and boosting Cedarville to beat the band." "They tell me that the alumni are getting busy on the proposition, too, and roping in freshies. Gee, won't the campus be green next fall?" "And none of 'em'll ever be sorry they came, either." "Say, haven't we had good times here this year?" "And that's not the best of it either. We've gotten something worth while, and when we're through here we'll be somebody and amount to something." "The Cedarville grads sure do, make good ; that's a cinch." "Well, let's rake in a few freshies ourselves." "Sure thing! Fifty freshmen in September! Sounds good to me!" 


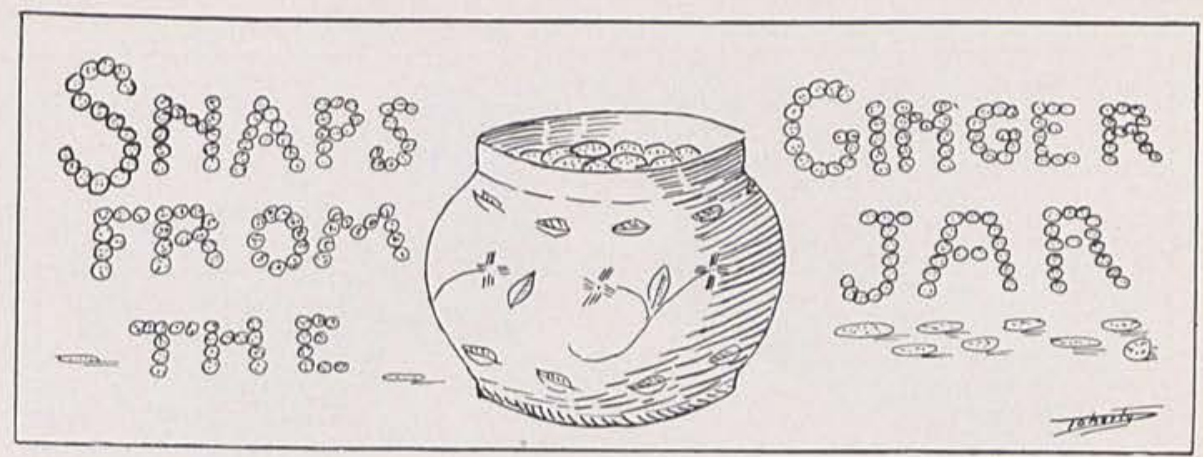

APPROPRIATE FLOWERS

Primrose Reba Harbison

Aster. Paul Duncan Rattlebox Ellen Tarbox

Bridle Wreath Freda. Trumbull Lady's Delight Nelson Thorne

Tulips Tacy Stanfield

Spring Beauty Louisa Greer

Chestnuts Jim

Heart's Ease Junior Class

Forget-me-not Senior Class

Evergreen Freshman Class

Puff Balls Sophomore Class

Touch-me-not Dorothy Smithson

Bittersweet Faculty

Daisy Helen Stewart

Rose

Nelson Thorne

Elder Bloom Margaret "Pair" Blossoms College Moon Flower. College

Peach

Morning Glory _-_ Edith Ramsey

"I fear very much that evon I am not sticking to facts these days," marked the postage stamp as Colman stuck it on a letter home.

Miss Rea (having just broken a flask) : "You see, we have to make many sacrifices in the interest of science."

Helen Creswell (seeing Bob going down the front walk) : "Well, I know I certainly am sacrificing a lot."

Margaret McCarty (waxing oratorical in class) : "Men may come and men may go, but I go on forever-_" (long pause).

Prof. MeChesney: "Why don't you go on, then?" 


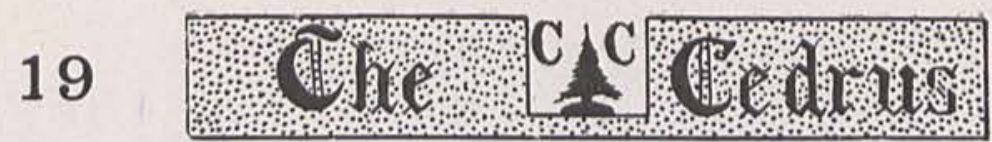

19

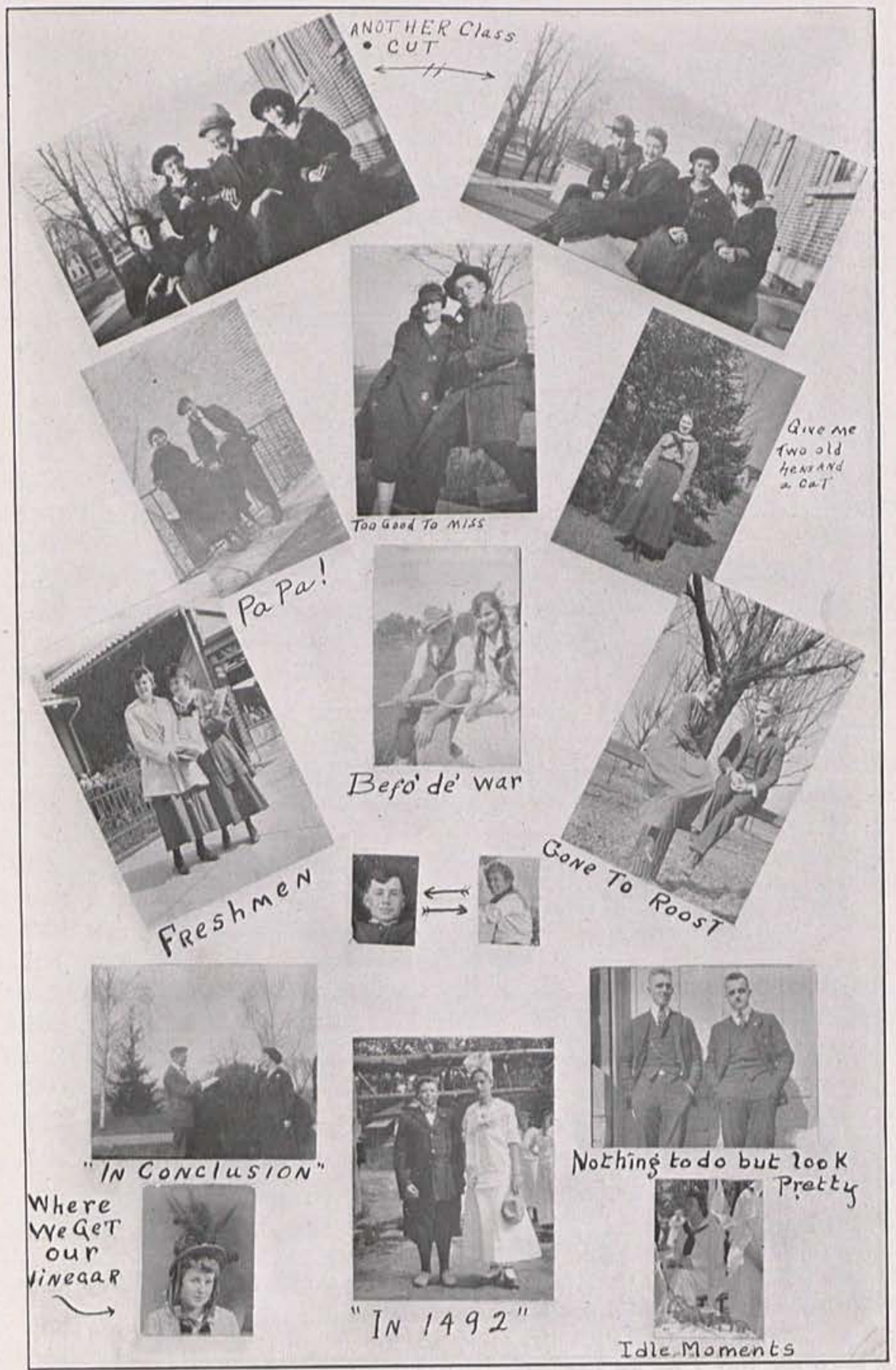




\section{CLUB GRACE (Three Times Daily)}

$\mathrm{Oh}$, please be merciful

And keep us "looking" fine;

Sixteen of us for dinner,

And grub for only nine.

Paul Duncan, to Dot, at the Club: "You shouldn't drink that coffee, Dot. It might stunt your growth. Look at me! I never drank it."

\section{OVERHEARD DURING HISTORY TEST}

Reba: "Ellen, when does Morton get his lessons?"

Ellen: "Well, search me-I know he doesn't study at night!"

Then she wondered why every one laughed.

Huey: "Oh, I love my work all right, but you know I never like to persecute things I love."

\section{CLUB HASH}

Consumer

Consumed

Louise McCullough-Dried "Beef" Gravy.

Harold Hammond-“Mayonnaise Dressing" on Lettuce.

Dorothy Smithson-Good "Winter" Apples.

Ernest Huey - Potatoes baked just "Wright" or a "Little" over done.

Freda Trumbull-Anything to keep her "Bill" down.

Margaret Elder-Raw oysters on "prayer meeting" night.

Robert Stewart- "Dates" at least four times a week.

Nelson Thorne-Oh, "Shaw," just a good, square meal.

Allen Turnbull- "Hash," "Eggs," "Limas," "Escalloped oysters," "Nuts" -"Helen."

Tacy Stanfield-Everything in sight.

Olive Finney - "Young Goat" and "Honey."

Robert Colman-Peaches "Eu la" mode.

Paul Duncan- "Dane-ish" Pudding and "Olives," never at the same time. Harvey Rickenbach-_Leavings" on Monday, Wednesday, and Friday.

Miss Alexander-“Lynn”berger Cheese.

F-ierce lessons.

L-ate hours.

U-nexpected company.

$\mathrm{N}$-ot prepared.

K-nocked out.

\section{LOGIC}

$A$-Nothing is better than a good lesson.-Faculty.

B.-A poor lesson is better than nothing.-Students.

C.-Therefore a poor lesson is better than a good one.

\section{A PLEA OF THE LATIN CLASS}

Latin is a dead, dead language, As dead as it can be;

It has killed all the Romans, And now it's killing me. 
Bradfute (translating French): "'I put my arm around her waist.' That's as far as I got."

Miss Schneder: "That's far enough."

Louise McCullough (when asked to conjugate "dono" in Latin) : "Dono -dono-dono-"

Prof. Jurkat: "Well, I guess you don't know."

\section{DEAD GIVE-AWAY}

Bob Colman (looking at the girls during May-Queen election) : "Good night, but don't those girls look fussed? Believe me, I know how I'd feel if they were voting for the most popular fellow in the College!"

Turney: "How much did it cost to have your shoes shined?"

Prof. Jurkat: "Ten cents."

Turney: "Gee! That fellow'd paint a barn for a quarter, wouldn't he?"

Miss Rea, (in Physics) : "What is a vacuum?"

Student: "I can't express it, Miss Rea, but I've got it in my head."

"Mr. Insley, I am glad to see you're back from the front?"

"I know I'm thin, but 1 didn't know I was tranparent."

Miss Schneder (in French): "This class is rather crowded, but I hope it is not too full for utterance."

\section{STUDENT PROVERBS}

Where ignorance is bliss, 'tis folly to be wise.

When joy and duty clash-let duty go to smash.

A word on the cuff is worth two in the book.

All the world loveth a cheerful bluffer.

People who call at McMillan's should not break out the front door glass.

A roving student gathereth no nineties.

A lesson in time saves nine (per cent).

Where there is a spread, there is a way to break it up (sometimes).

Cut lab. and go to the movies every chance you get.

It is never too late to study. 


\section{9 mor.}

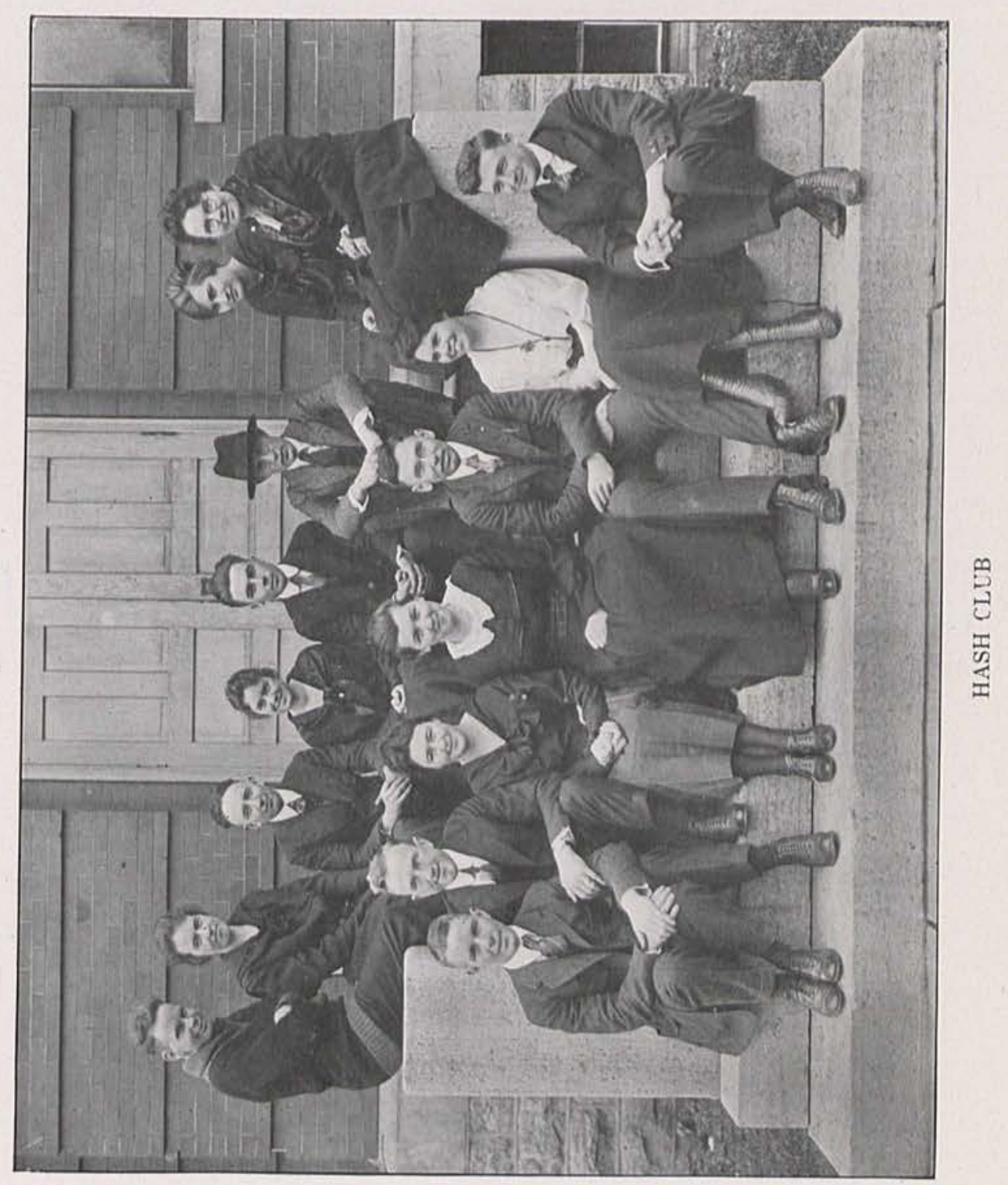




\section{Che Cedrus 19

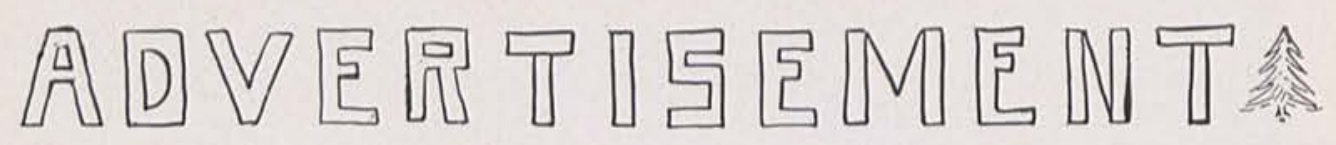

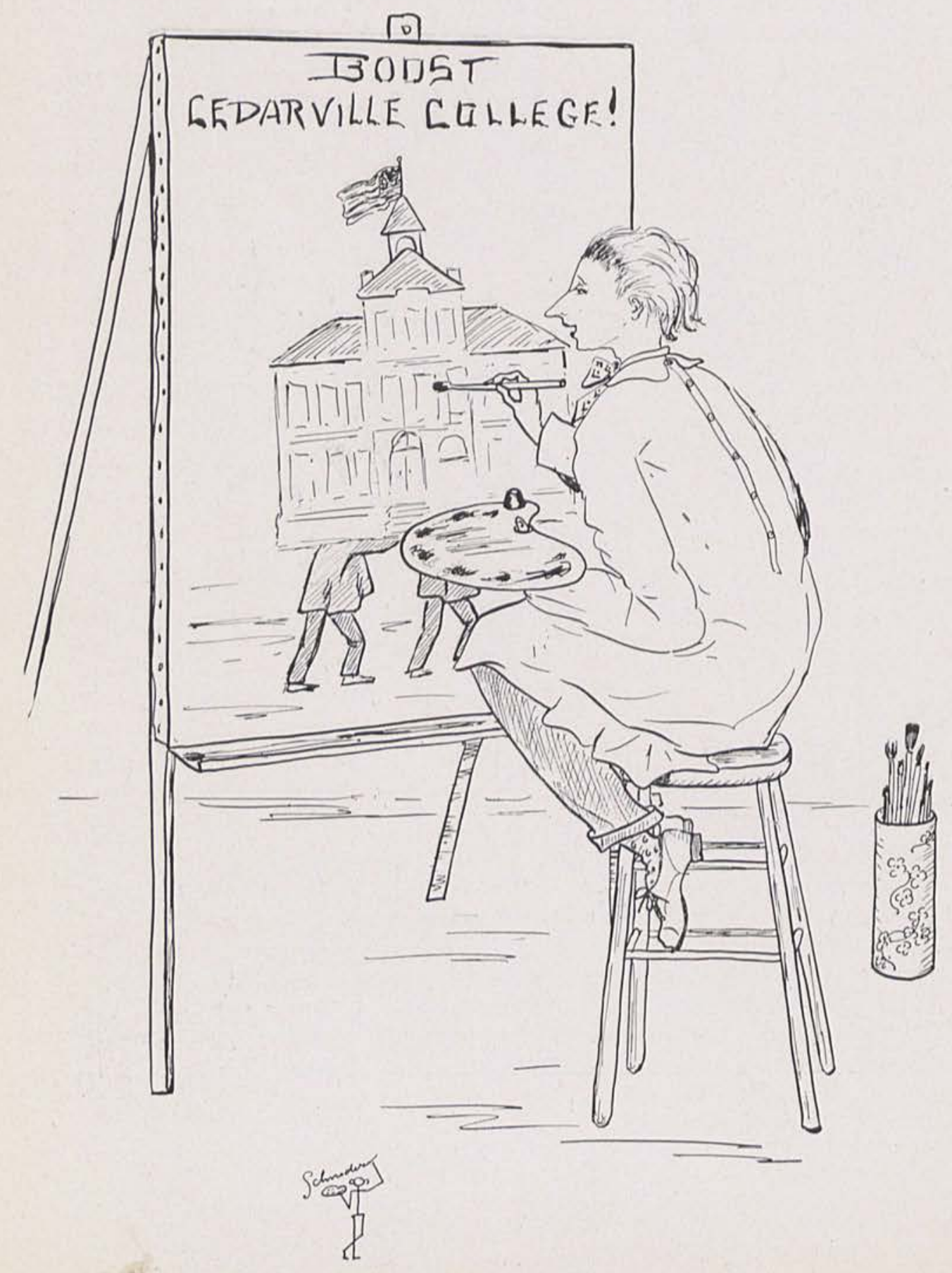




\section{9}

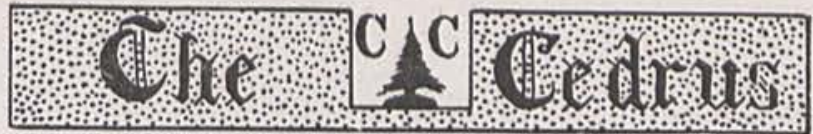

\section{Cedarville College}

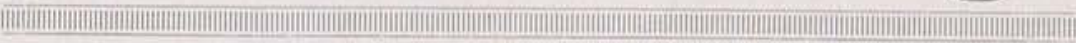

GET A COLLEGE TRAINING.

The times demand it.

The results justify it.

COME TO CEDARVILLE COLLEGE.

The location is healthful and beautiful.

The opportunities are fine and inspiring.

The courses are complete and modern.

The influcnces are safe and helpful.

The expenses are lower than at many other places.

The students are possessed of high ideals an 1 practice them.

The Faculty is experienced and thor sughly trained.

The College is recognized by the Department of Public Edu. cation of the State of Chio, and by the leading universities.

In Cedarville Collece you can get preparation for any pursuit in life.

Fifty Frcshmen are expected to enroll in September. Th? prospects for a record-breaking attendance are splendid.

TWENTY-SIXTH YEAR OPENS SEPTEMBER 10, 1919.

For catalogue and further particulars, address

\section{W. R. McChESnEY, Ph. D., D. D President Cedarville, Ohio}




\section{9

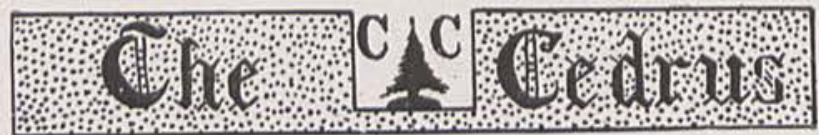 \\ The Evening Passes Pleasantly}

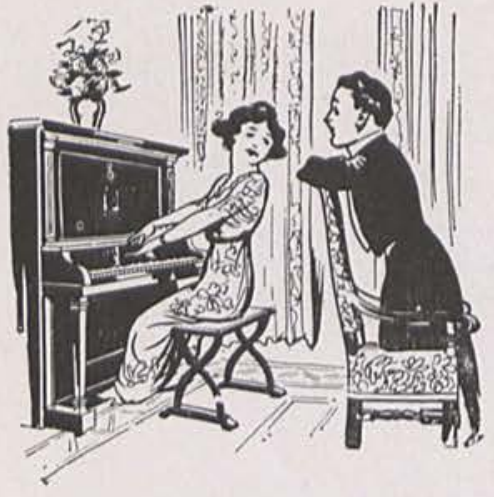

Representative for Cedarville Knox F. Hutchison

when it is enlivened with some good music. And how can it be had unless there is a good Piano or Player-Piano in the home? If there is none in yours, by all means come and supply the deficiency at once. Our pianos are famous for their musical beauty. Our terms are such that to be without one is absurd.

\section{SAWHILL-DOLBEER CO. \\ HIGH AND GENTER \\ SPRINGFIELD, OHIO}

\section{Cedarville Theological Seminary}

ORGANIZED IN 1810

Regular three years' course.

Combined Arts-Theology Course for A. B. Degree.

Thorough preparation for the gospel ministry, and mission and evangelical work.

Open to students from all churches.

NEXT SEMESTER BEGINS SEPTEMBER 10, 1919

For further information, address

Dean

W. R. McChesney, Ph. D., D. D. 


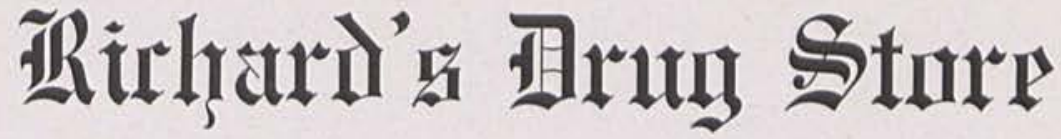

\section{SAlure thant pline}

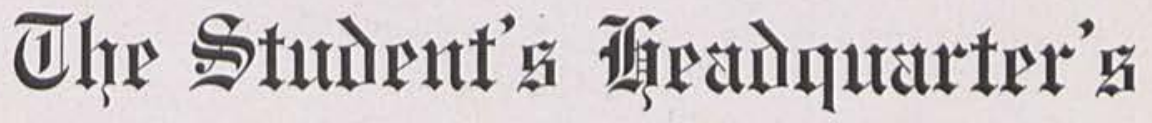

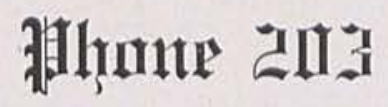

\author{
(Tentartitlle, (1)hịin
}

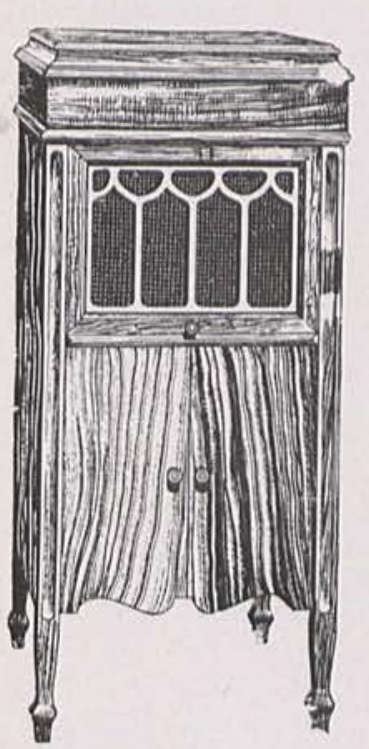

\section{WREN'S}

\author{
BETTER MUSIC FOR THE HOME
}

\section{Che Qheney Phonograph}

To endow the home with an inexhaustible fund of the very finest music-such is the mission of the Cheney.

Musicians of distinction have endorsed and adopted the Cheney.

This matchless instrument employs distinctly new princioles of tone reproduction, protected by new basic patents under exclusive Cheney ownership and control.

Sold By

\section{The Edward Wren Co.}

Springfield, Ohio 


\section{9

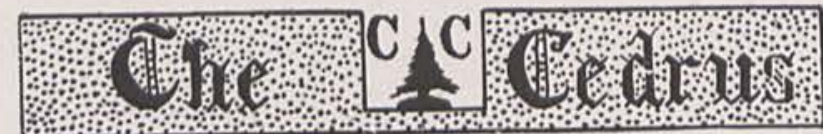 \\ STANDARD ICE CREAM \\ GOODNESS - How You'll Like It}

\section{SOLD IN CEDARVIILE BY \\ A. E. RICHARDS BRICK ICE CREAM ALWAYS \\ IN STOCK}

\section{SPRINGFIELD DAIRY PRODUCTS CO. SPRINGFIELD, OHIO}

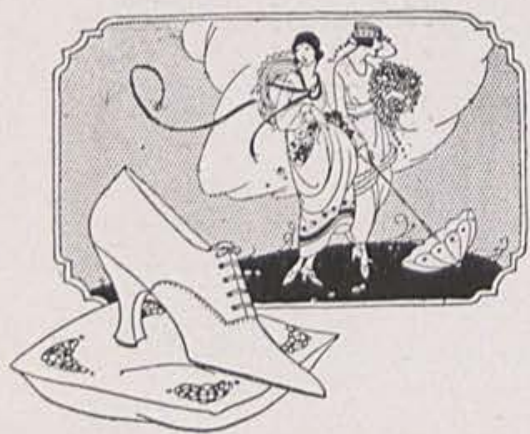

SPRING MODES WERE NEVER SO ALLURING IN COLOR, SO SMART AND DISTINCTIVE IN STYLING -

As the lovely New Wraps, Capes, and Frocks which the store now presents, as well as the delighfully interesting Blouses of 'Crepe Georgette and gay Sport Skirts. Madame Fashion shows no favoritism, as you will find when you select a charming Spring Hat or Smart Footwear. Visit our Dry Goods section and note how attractive the new Silks, Voils, and Organdies are, and how distinctive the patterns and colorings.

\section{JOBE BRO'THERS COMPANY}

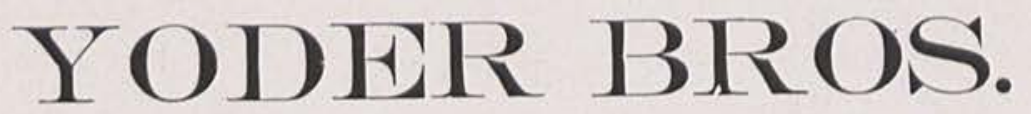

Successors to E. A. Allen

GRAIN, SEEDS, COAL, HARDWARE, AND IMPLEMENTS

Phone 2-2I

Cedarville, Ohio 


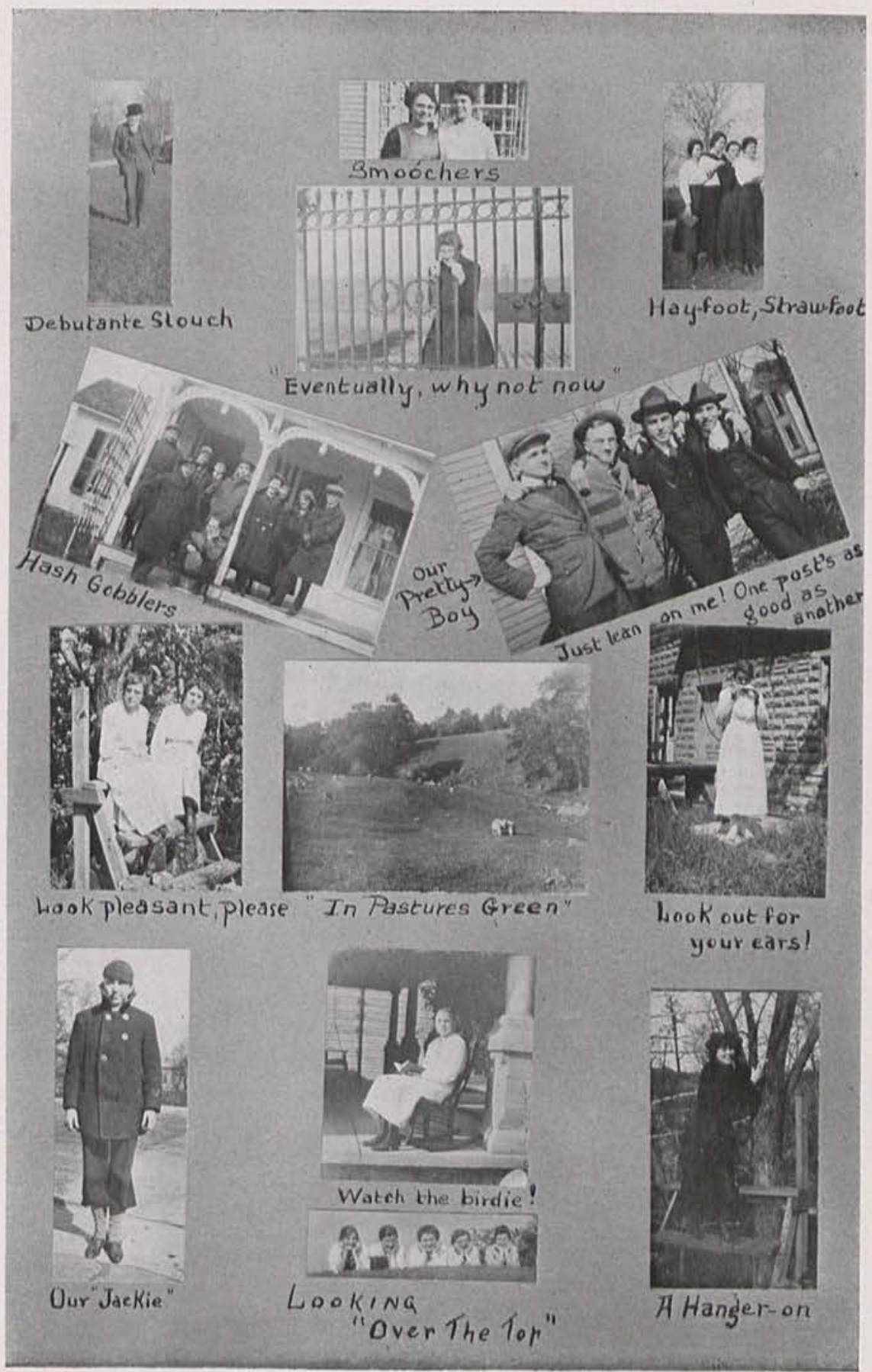




\section{9

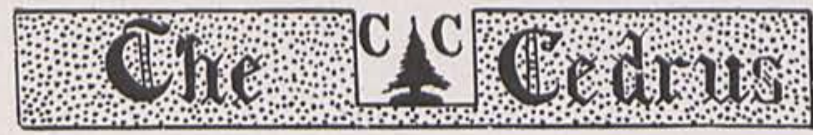 \\ 19 \\ The Tarbox Lumber Co.}

Have a complete line of BUILDING MATERIALS

Estimates cheerfully made. Best grades at

reasonable prices.

\section{Phone 33}

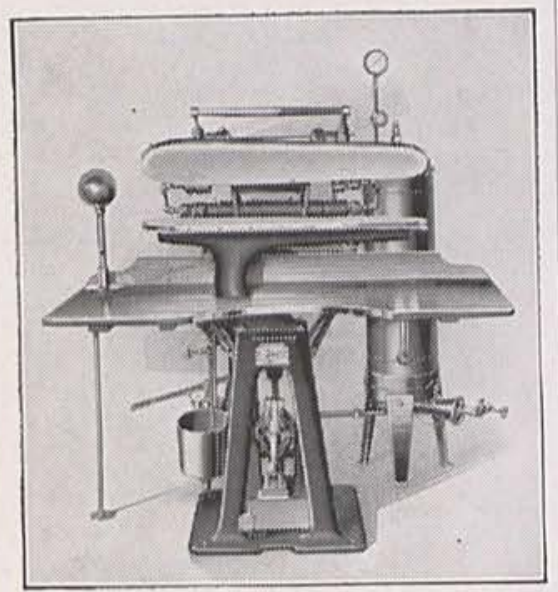

Odorless Dry Cleaning

Sanitary Steam Pressing

Hats Cleaned and Blocked

Highest Made-to-Measure Clothes

We Guarantee All Work

T H E

Fashion Shop

Both Phones

19 Green St.

Xenia, Ohio

\section{Cedarville, Ohio}

\section{Choose the \\ Instrument \\ The World's \\ Greatest \\ Artists Have \\ Chosen}

Could you ask a safer guide? Certainiy no one is bette: qualified to judge a musical instrument. They

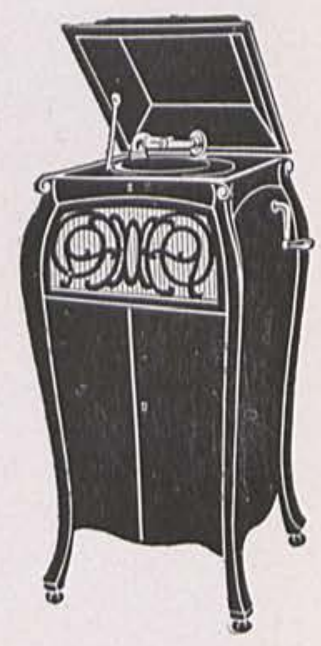
know music. Their

life-work is music. And Melba, MeCormack, Caruso. Farrar, Galli-Curci, Gluck, Homer, and a host of other world-famed artists have chosen the Victrola to carry their superb art on Victor Records exclusively to all the world.

Victors and Victrolas $\$ 10$ to $\$ 400$. Call and let us give you a demonstration

\section{Victrolas}

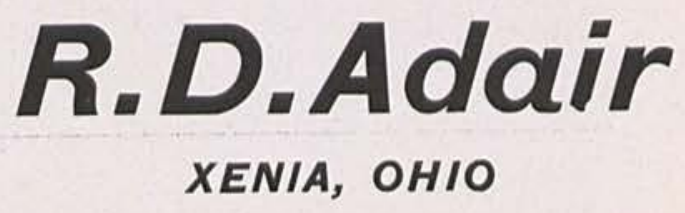




\title{
19
}
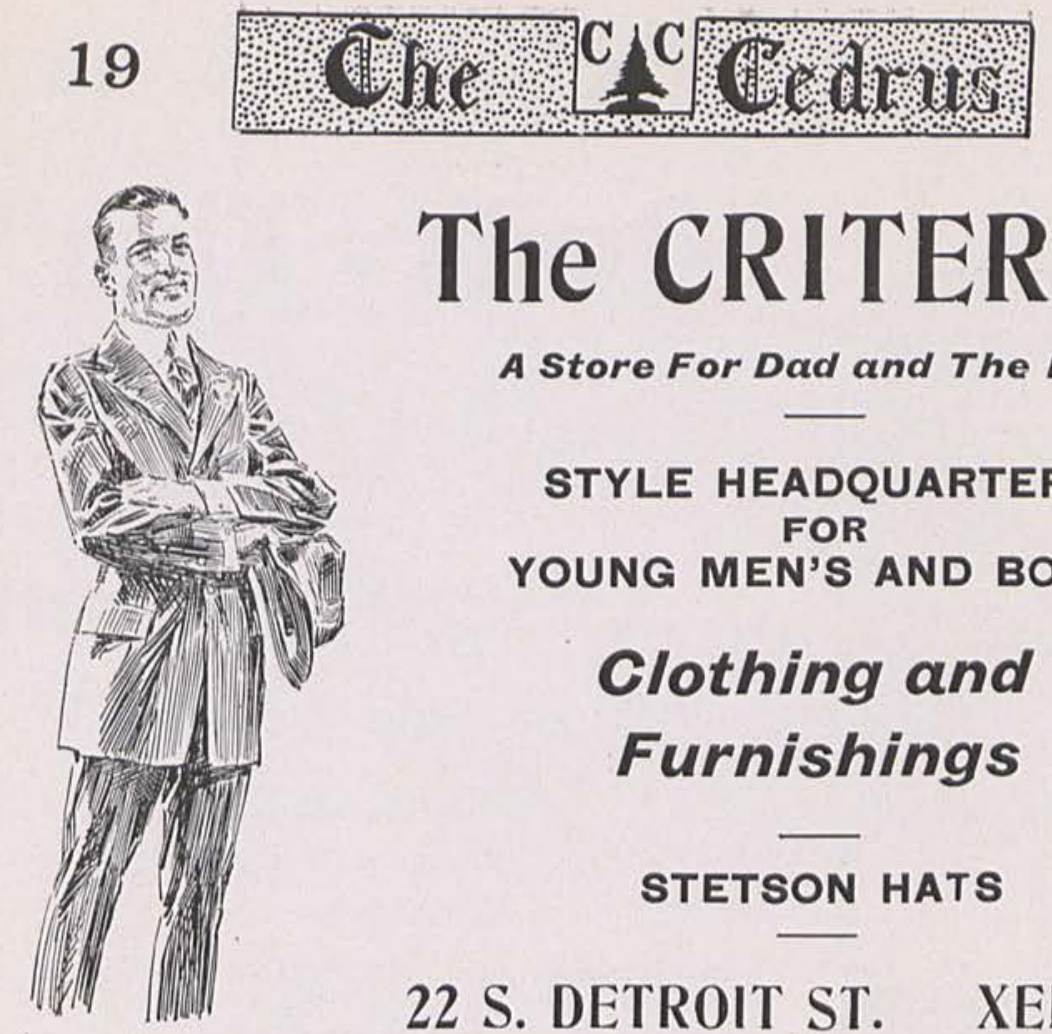

\section{The CRITERION}

A Store For Dad and The Boys

\author{
STYLE HEADQUARTERS
}

FOR

YOUNG MEN'S AND BOYS'

\section{Clothing and}

Furnishings

STETSON HATS

22 S. DETROIT ST. XENIA, 0.

\section{T H E

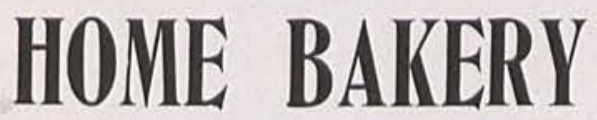

Bakes fresh Bread every day.

Delicious Pies, Cakes, and

Pastries a Specialty

Delivery Every Day.

JACOB SIEGLER

Phone 65

\section{WHEELER}

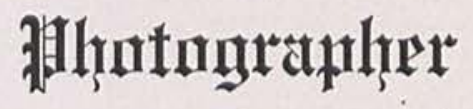

Green Street Xenia, Ohio

\section{The Cedarville Herald}

ESTABLISHED 1878

Commercial Printing of All Kinds

Cedarville, Ohio 


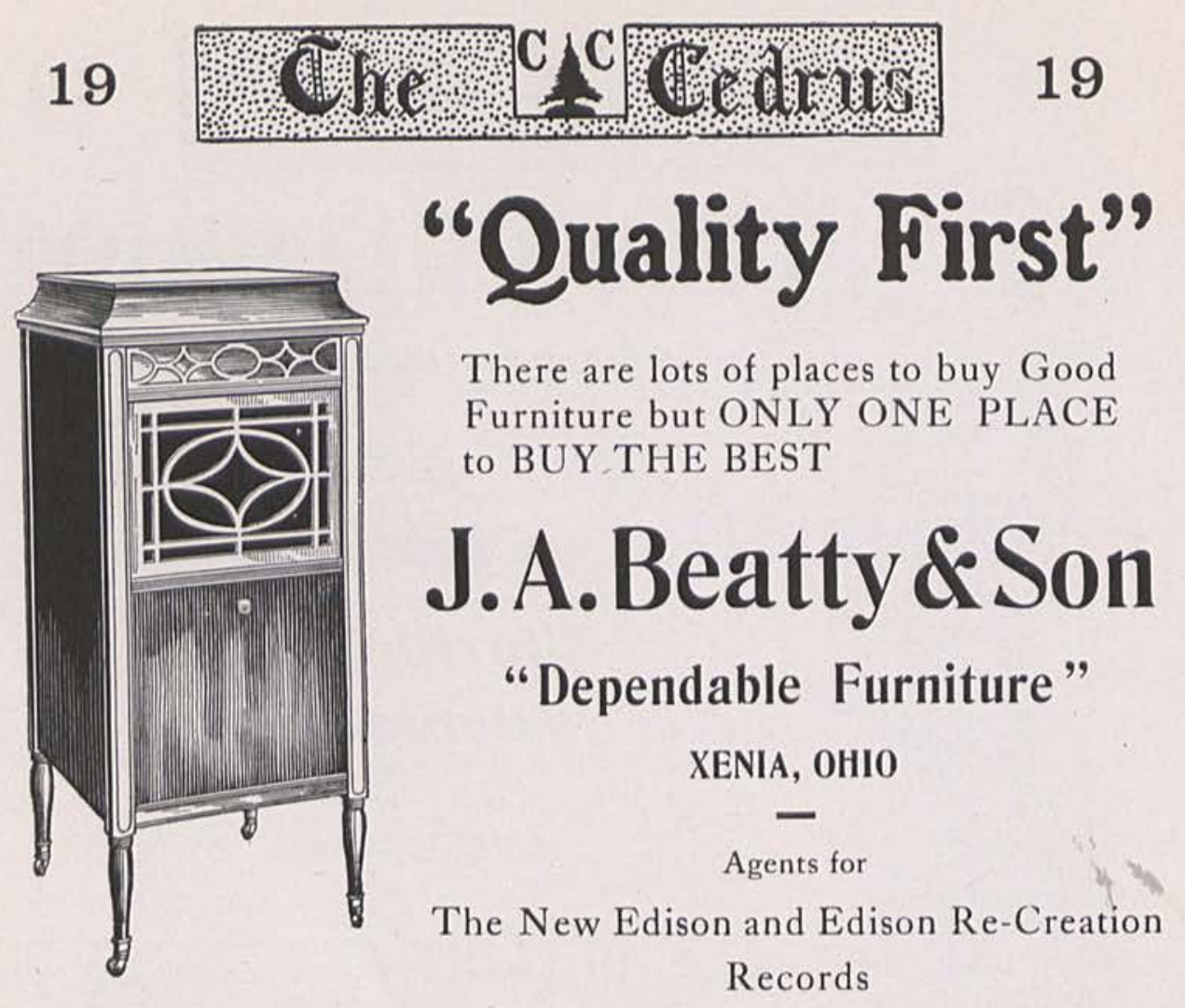

Hammond: "Rickey, I don't believe you've broken your glasses for a long time, have you?"

Rickenbach: "I've only broken them once since I got a case."

Louise Finney (thoughtfully) : "Do you suppose I could get a new case put on my watch?"

The Other Louise: "Sure, you could get a case on anything!"

\section{CANBY'S ART GALLERY XENIA, OHIO}

\section{THE NEW \\ Cedar Inn}

Home Cooked Meals

American or European MOCK BROS., Props.

\section{R. A. Imurdock}

AUTHORIZED FORD SALES

AND SERVICE

Phone 55

Cedarville, Ohio 


\section{9}
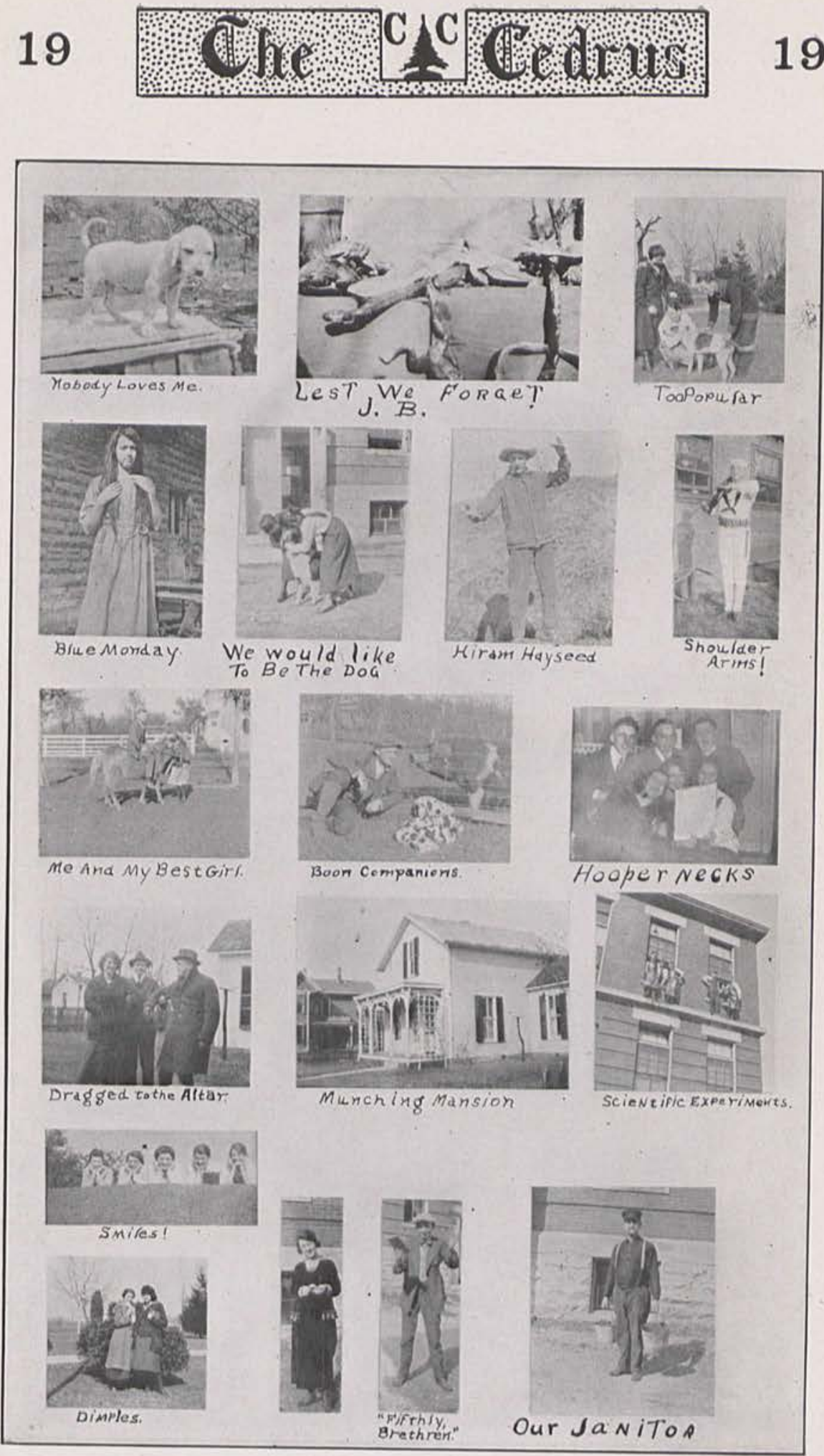


\section{9

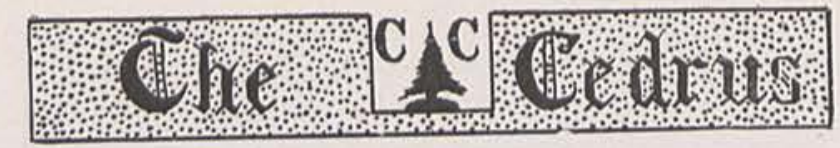 \\ \$TOP! LOOK! LI\$TEN! \\ On Account of LOW RENT\$ and Other RUNNING \\ EXPEN\$E\$, U Can Get BETTER VALUE\$ by \\ Buying Your}

Clothing, Hats and \$hoes

At

\section{HOME CLOTHING CO.}

\section{LEO A NDERSON, D. V. M. \\ Veterinarian \\ CEDARVILLE, OHIO}

\section{Babb Means Best}

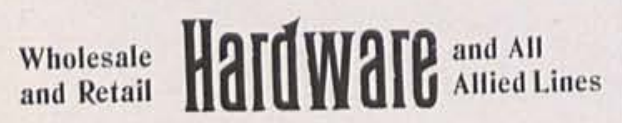

Sporting Goods

Pennsylvania Tires and

Ton-Tested Tubes

C. L. Babb

16 South Detroit Street

Xenia, Ohio
If You Want

SERVIICE and QUHLITY

Call on

The New Grocerman

C.E.Masters

Phone 44

Cedarville, Ohio 


\section{9

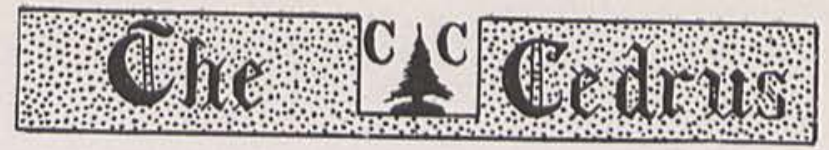 \\ Hutchison \& Gibney}

Thank patrons of the College and our store for their great interest.

THE COLLEGE is doing a great work in building character.

HUTCHISON \& GIBNEY call attention to their Basement Bazaar. Short lengths saving 25 per cent to their customers.

SHEETING, TICKING, PRINTS, PERCALES, GINGHAMS-also China Ware, Stoves, Kitchen Cabinets, Rugs, Linoleum, Lace Curtains, Aluminum Kitchen Utensils. Do not forget the Coats, Suits, Waists, Skirts, Corsets, Underwear.

Bradfute: "You must have a wonderful memory to keep all the things in your head that you do."

Colman: "I never forget anything when it is once there."

Bradfute: "How about that pencil I loaned you last week?

Colman: "Aw, that's different; I put that in my pocket."

\section{A MICROSCOPIC GRADE}

Ida Rees (going to Economic exam.) : “After I finish this, you won't be able to see my grade with a microscope."

Prof. Allen (overhearing remark) : "It will be a pretty fine grade, then, won't it?"

Allen Turnbull: "Girls are like street cars-one comes along every ten minutes, and if you wait long enough, you can get the same one coming

Bell Phone 681

\section{FLOYD ANDERSON, FLORIST FLOWERS FOR ALL OCCASIONS \\ TELEGRAPH DELIVERY SERVICE}

XENIA, OHIO

\section{GALLOWAY \& CHERRY}

\section{East Main Street}

\section{Xenia $==$ Ohio}

\section{DR. O. P. ELIAS DENTIST}

Phone 87

Exchange Bank Bldg. 


\section{9}

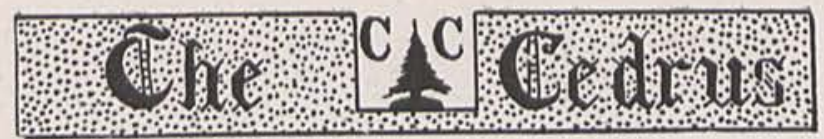

\section{ROBERT BIRD \& SONS CO.}

THE STORE THAT THE STUDENTS MAKE THEIR HEADQUARTERS WE TRY TO PLEASE THEM

For the GIRLS

A full line of Furnishing Goods, Kid Gloves, Corsets, Silk Hosiery, Silk Waists, Shoes, etc.

For All STUDENTS

Tennis and Basket Ball Shoes, Sweaters, Pennants, etc.
For the BOYS

Wilson Bro. Famous Shirts; Rice and Hutchins Shoes; Royal Tailored Suits; Snappy, Stylish Hat and Caps; Nifty Neckties, Ar row Collars, P. Q. A. Underwear, Silk Socks, Belts and other Mer chandise of merit.

We take this opportunity to thank all the studicnis for thoir patronage.

COME AGAIN

Bob Colman: "When traveling o'er the sea of life, don't rest on your oars and drift along - get out and push."

Reba: "Becky, don't you think we should have a dean of women here?"

Rebecca: “Reba, you oughtn't to kick when you have a 'Dean' of your own."

\section{Charters \& Wagner Optometrists}

44 E. Main St.

Xenia, Ohio

Eyes carefully Examined, Tested, and Fitted by means of the latest and most modern scientific methods.

Special attention given to Muscular Imbalance and the correction of same.

Try a pair of our Toric Kryptoc Bifocals in the latest style Windsor frames.

Give us a call and save your Eyes.

\section{TRY THESE OVER ON YOUR} PIANO

"Sweethearts" - Becky and Her Beau.

"You're the Most Wonderful Girl" - Robert Stewart.

"You Made Me Love You"-Robert Colman.

"Peg o' My Heart"-Margaret Elder.

"I'll Get Hu (ey)"-Louise Finney.

\section{Hotel and Restaurant}

\author{
H. A. McLEAN, Prop.
}

Phone No. 60

Xenia Avenue

CEDARVILLE, OHIO 


\section{SATISFACTION GUARANTEED}

The aim of our service is to satisfy you. Any time you feel you didn't get everything you should, come back, - we'll gladly meet you with a proper adustment.

Hart Schaffner \& Marx and Fashion Park Clothes

\section{A. WEAVER}

A little girl going to kiss Paul Duncan.

Miss Elder: "Oh, I wouldn't, it isn't nice."

Miss Greer: "Oh, $I$ would!"

Prof. Jurkat: "When Helen Creswell changes her name, how are you going to tell her from Helen Stewart?"

\section{S. BARNES \& $C O$. Decorators}

Both Phones Green Street

Xenia, Ohio

OHAS. S. JOHHSON

\section{House Decorator}

Wall Paper, Paints, Glass, Brushes, Etc.
ASK

Hammond, if he had a machine, where he'd Park-er.

Stewart if his health required frequent visits to the country.

Huey how it seems when one is not Wright.

Cecil Rife if he ever had a dats.

Louisa what she would do if the frost nipped her Bush.

\section{When in Dayton Visit Marcus's Cloak Shop 35 S. Main Street}



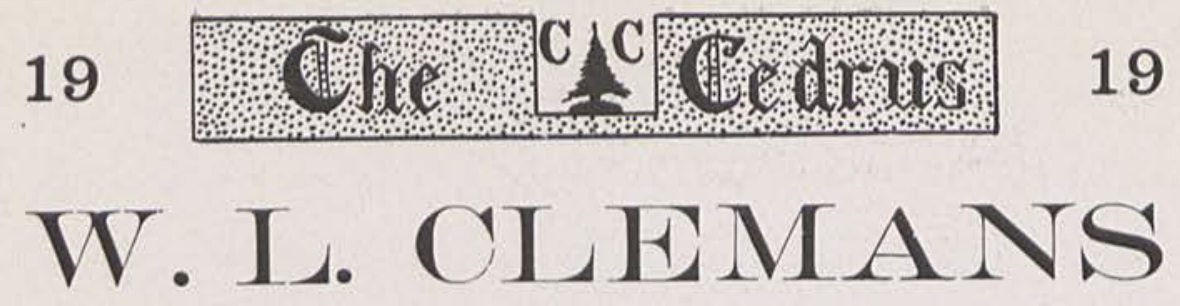
REAL ESTATE, IOANS
A N D

INSURANCE AGENCY

Establishrd 1896

CEDARVILLE, OHIO

Of superior equipment, facilities, and ability
OF hile considering the purchase of Memorial Work,
The GeOrge Dodds \& S0IS Grallite C0.
KEENE, N. H.
(Awarded first prize as the finest Granite and Marble works in the U. S.)
Write for free copy of handsome Art Booklet today

\title{
GEMS FROM THE POETRY CLASS
}

Roger Collins (reading) : "Lo in yon brilliant winder-neech!” (repeated six times).

Miss Schneder: "What is meant by, 'The frail bark on the sea,' Mr. Creswell?"

Morton: "I suppose it means the noise the waves were making."

Miss Schneder (criticizing Louisa, who had just read The Problem) : "There is one fault in your reacing-your voice is suited only to love poems."

\section{Grow With Us!}

Place your savings with us on which we pay $4 \%$ interest compounded semi-annually

\section{THE EXCHANGE BANK}

\author{
CEDARVILLE, OHIO
}

CAPITAL AND SURPLUS

$\$ 65,000.00$
RESOURCES AND LIABILITIES

$\$ 500,000.00$ 


\title{
19
}

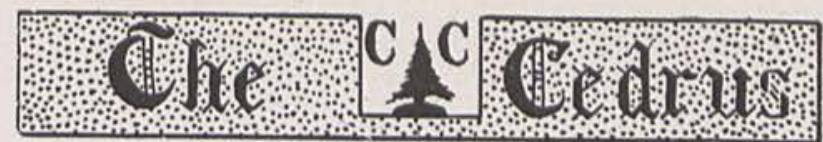

\section{STOP AND GET}

\author{
BEST GOODS AT BEST PRICES \\ SPOT CASH STORE
}

\section{W. W. Trout Grocery Co. CEDARVILLE, OHIO}

\section{J. VICTOR TARR}

AR'TIS'T

\author{
CEDARVILLE, OHIO
}

AS GOOD AS THE BEST, BETTER THAN THE REST

\section{PHOTOS FNLARGEMENTS FRAMES}

\section{R. H. EDW ARDS}

GROCERIES

BELL PHONE 13
ICE CREA M

COME AND SEE US
SOFT DRINKS, FTC.

CLIF'TON, OHIO

THE COLLEGE IN SONG AND STORY

"Alice, Where Art Thou?"

"Lonesome-I'm Awfully Lonesome"

Duncan

"I Love a Lassie, a Bonnie, Bonnie Lassie" Chesnut "Life of Paul"

World Encyclopedia Thorne

"I Want a Girl" Alice Danes Prof. Jurkat

"Inquiry Con club "Good-Night, Little Girl" ( "Lives of Great Men"

"Mighty Lak a Rose".

"Two Little Love Bees"-

"Love's Old Sweet Song"

"I Fear No Power a Woman Wields" M. Stormont Faculty Louisa Greer

"She Came and Went"

"Song of Myself"

"Turn Back the Universe and Give Me Yesterday" $\mathrm{ob}$ and Helen Rickenbach Colman Huey Bradfute Edith Ramsey 
19

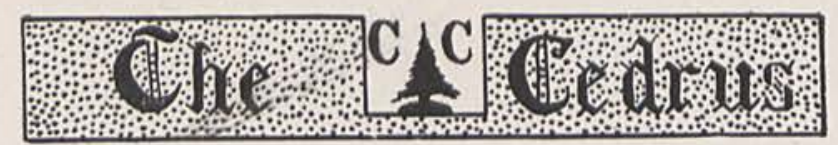

19

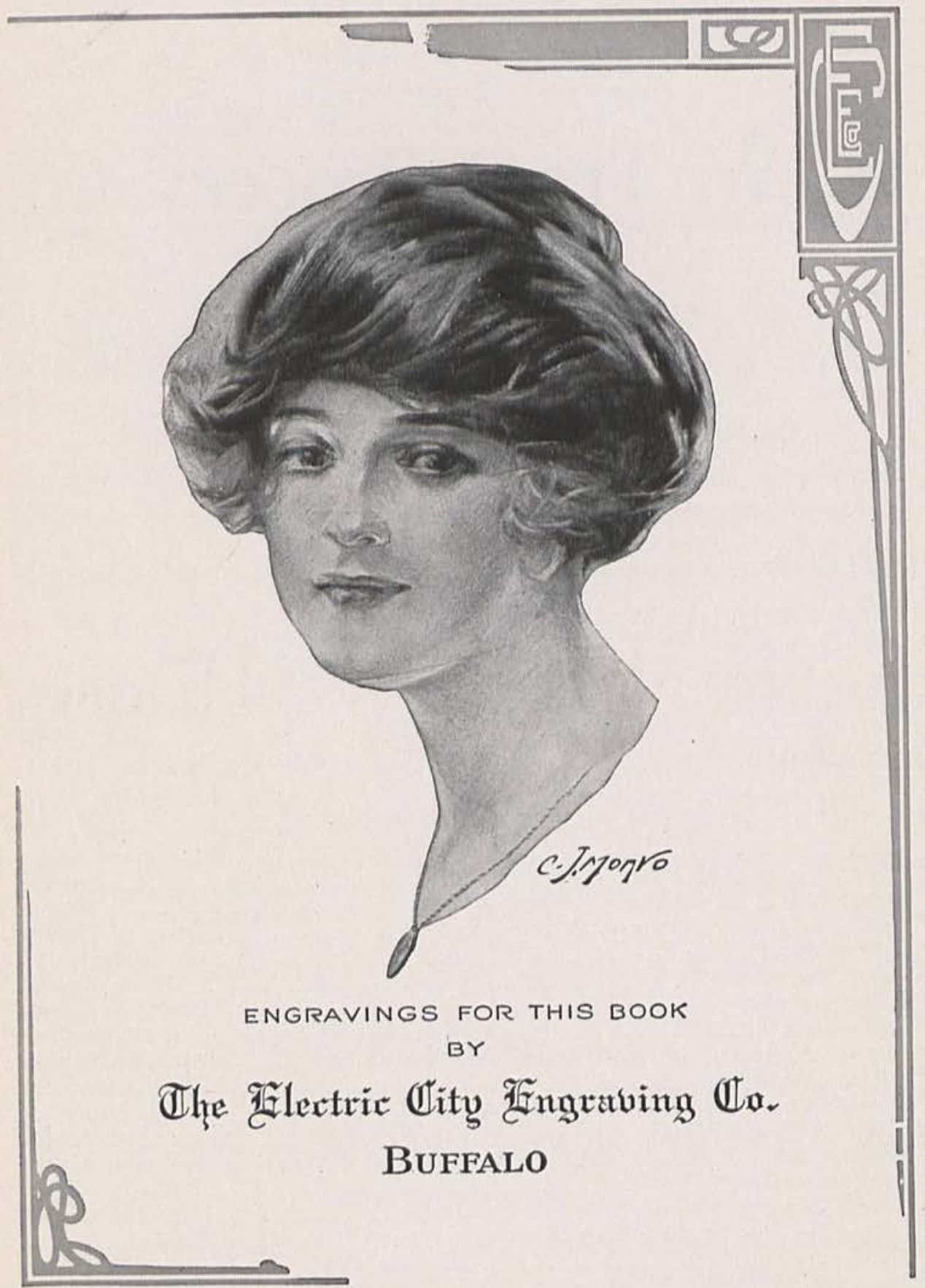




\section{9}

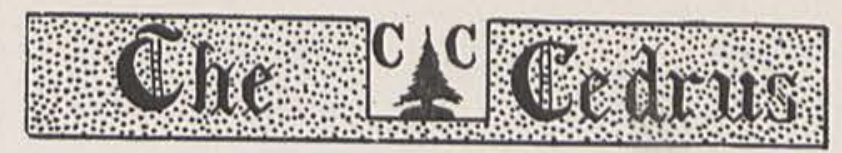

19

\section{Printers of this Annual}

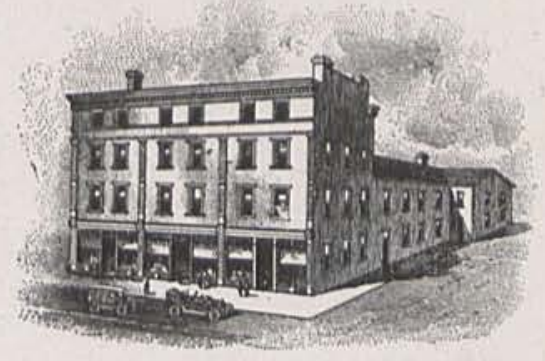

\section{The}

\section{Aldine Publishing House}

Geo. I. Graham \& Co.

\section{College Publications}

Printing - Fingraving - Binding

Samples and Prices on Request

19-23 S. Detroit St. Xenia, Ohio 




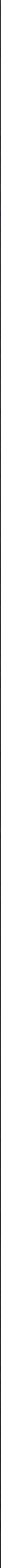

